\title{
ESTUDO EPIDEMIOLÓGICO DO VÍRUS DA RAIVA EM MAMÍFEROS SILVESTRES PROVENIENTES DE ÁREA DE SOLTURA NO LITORAL NORTE DO ESTADO DE SÃO PAULO, BRASIL
}

Tese apresentada ao Programa de Pós-Graduação Interunidades em Bioteconlogia USP/ Instituto Butnatan/IPT, para obtenção do Titulo de Doutor em Biotecnologia 


\section{ESTUDO EPIDEMIOLÓGICO DO VÍRUS DA RAIVA EM MAMÍFEROS SILVSTRES PROVENIENTES DE ÁREA DE SOLTURA NO LITORAL NORTE DO ESTADO DE SÃO PAULO - BRASIL}

Tese apresentada ao Programa de PósGraduação Interunidades em Bioteconlogia USP/ Instituto Butnatan/IPT, para obtenção do Titulo de Doutor em Biotecnologia

Área de Concentração: Biotecnologia

Orientador: $\mathrm{Dr}^{\mathrm{a}}$ Silvana Regina Favoretto Lazarini

Versão corrigida. A versão original eletrônica encontra-se disponível tanto na Biblioteca do ICB quanto na Biblioteca Digital de Teses e Dissertações da USP (BDTD). 
DADOS DE CATALOGAÇÃO NA PUBLICAÇÃO (CIP)

Serviço de Biblioteca e Informação Biomédica do Instituto de Ciências Biomédicas da Universidade de São Paulo

reprodução não autorizada pelo autor

Araujo, Danielle Bastos.

Estudo epidemiológico do vírus da raiva em mamíferos silvestres provenientes de área de soltura no litoral Norte do Estado de São Paulo, Brasil / Danielle Bastos Araujo. -- São Paulo, 2012.

Orientador: Silvana Regina Favoretto.

Tese (Doutorado) - Universidade de São Paulo. Instituto de Ciências Biomédicas. Programa de Pós-Graduação Interunidades em Biotecnologia USP/IPT/Instituto Butantan. Área de concentração: Biotecnologia. Linha de pesquisa: Virologia.

Versão do título para o inglês: Epidemiologic study of rabies virus in wild mammals from a release area, North coast of São Paulo State, Brazil.

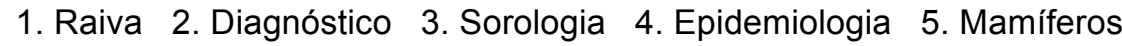
silvestres 6. Brasil I. Favoretto, Silvana Regina II. Universidade de São Paulo. Instituto de Ciências Biomédicas. Programa de PósGraduação Interunidades em Biotecnologia USP/IPT/Instituto Butantan III. Título. 
UNIVERSIDADE DE SÃO PAULO

Programa de Pós-Graduação Interunidades em Biotecnologia

Universidade de São Paulo, Instituto Butantan, Instituto de Pesquisas Tecnológicas

Candidato(a):

Título da Tese:

Orientador(a):
Danielle Bastos Araujo.

Estudo epidemiológico do vírus da raiva em mamíferos silvestres provenientes de área de soltura no litoral Norte do Estado de São Paulo, Brasil.

Silvana Regina Favoretto.

A Comissão Julgadora dos trabalhos de Defesa da Tese de Doutorado, em sessão

pública realizada a

( ) Aprovado(a)
................., considerou

( ) Reprovado(a)

\footnotetext{
Examinador(a): Assinatura:

Nome:

Instituição:

Examinador(a): $\quad$ Assinatura:

Nome:

Instituição:

Examinador(a): Assinatura:

Nome:

Instituição:

Examinador(a): $\quad$ Assinatura:

Nome:

Instituição:

Presidente: Assinatura:

Nome:

Instituição:
} 


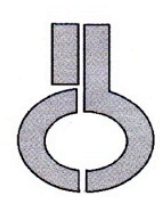

UNIVERSIDADE DE SÃO PAULO INSTITUTO DE CIÊNCIAS BIOMÉDICAS

Cidade Universitária "Armando de Salles Oliveira" Av. Prof. Lineu Prestes, 2415 - CEP. 05508-000 São Paulo, SP - Brasil Telefone :(55) (011) 3091.7733 - telefax : (55) (011) 3091.7438 e-mail: cep@icb.usp.br

\section{Certificado}

Certificamos que o protocolo registrado sob $n^{\circ} \mathbf{4 3}$ nas fls. 69 do livro 02 para uso de animais em experimentação, sob a responsabilidade do Prof(a) Dr(a Silvana Regina Favoretto, Coordenador(a) da Linha de pesquisa Estudo epidemiológico do virus da raiva em mamiferos silvestres provenientes de área de soltura do litoral norte do Estado de São Paulo, Brasil do qual participou(aram) o(s) alunos

Danielle Bastos Araújo, Angélica Cristine de Almeida Campos e o pesquisador Edison Luiz Durigon está de acordo com os Princípios Éticos de Experimentação Animal adotado pela Sociedade Brasileira de Ciência de Animais de Laboratório (SBCAL) e foi aprovado pela COMISSÃO DE ÉTICA EM EXPERIMENTAÇÃO ANIMAL (CEEA) em 17.06.09, com validade de 3 anos.

São Paulo, 18 de junho de 2009.
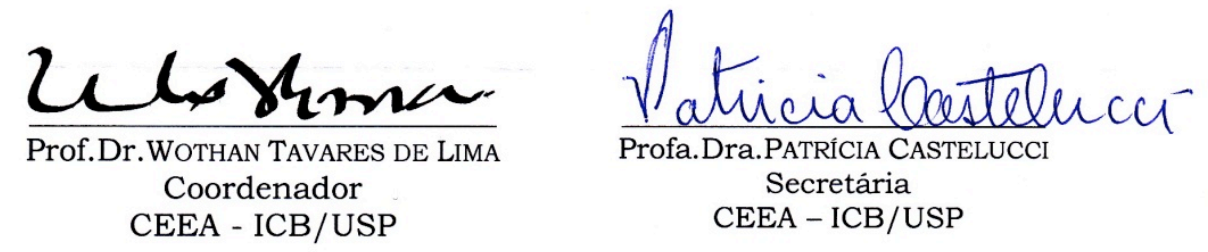
"Aprendi que todo mundo quer viver no cimo da montanha, sem saber que a verdadeira felicidade está na forma de subir a escarpa...

...É necessário abrir os olhos e perceber que as coisas boas estão dentro de nós, onde os sentimentos não precisam de motivos nem os desejos de razão. $O$ importante é aproveitar o momento e aprender sua duração, pois a vida está nos olhos de quem sabe ver." 


\section{AGRADECIMENTOS}

Aos meus pais Mara e Emilson pelo apoio e auxílio durante toda a minha trajetória.

A minha orientadora Silvana Regina Favoretto por me aceitar como orientada, por toda a ajuda em todos os momentos do desenvolvimento da tese e do doutorado assim como pela inspiração profissional.

A Gaia Consultoria Ambiental pela oportunidade de parceriapara a realização deste projeto. Ao Luiz Francisco Sanfilippo e a todos os biólogos e veterinários da Gaia (Aziz, Celina, Maíra, Maria Fernanda, Débora) e especialmente a todos os funcionários da Fazenda Acaraú pela imensa ajuda na captura de animais e coleta de amostras.

As amigas do Núcleo de Pesquisas em Raiva Angélica Cristine de Almeida Campos e Camila Seabra pela ajuda no projeto e principalmente pelo apoio em diversos momentos.

As Dras. Luzia Fátima Alves Martorelli, Ana Paula Kataoka e Marilene Fernandes do Centro de Controle de Zoonoses de São Paulo pela parceria na realização das provas sorológicas e por todos os ensinamentos e conselhos.

A Dra. Elenice Sequetin Cunha do Instituto Biológico de São Paulo pela ajuda, atenção e parceria na realização das técnicas diagnósticas. E a Dra. Luzia Queiroz pela ajuda nas coletas e em diversos momentos.

Ao Dr. Edson Luiz Durigon por me receber no Laboratório de Virologia Clínica e Molecular.

A todos os alunos e funcionários do laboratório de Virologia Clínica e Molecular que passaram ou continuam no laboratório ajudando direta e indiretamente no desenvolvimento desta pesquisa. 
As Dra. Florence Cliquet, por me receber, e a Dra. Marine Wasniewski, pela atenção, ajuda e orientação, do Laboratório de Raiva e Animais Silvstres da ANSES na cidade de Nancy France. Assim como aos técnicos, Laetitia, Johnatan e Anuock, e a todos os pesquisadores e funcionários deste laboratório, por toda a atenção e paciência (em outro idioma) dispensados.

Aos funcionários da secretaria do Programa de Pós-graduação em Biotecnologia, Fábia, Elaine e Marcos, pela disponibilidade (mesmo em cima da hora...). 


\section{RESUMO}

ARAUJO, D. B. Estudo epidemiológico do vírus da raiva em mamíferos silvestres provenientes de área de soltura no litoral Norte do Estado de São Paulo, Brasil. 2012, 104f. Tese (Doutorado em Biotecnologia) - Instituto de Ciências Biomédicas, Universidade de São Paulo, São Paulo, 2012.

A raiva é uma enfermidade infecto-contagiosa de caráter zoonótico responsável por milhares de mortes de seres humanos e animais em todo o mundo. A crescente importância do ciclo silvestre, envolvendo morcegos e mamíferos terrestres, demonstra a importância do estudo da epidemiologia do vírus da raiva nessas espécies; a fim de se determinar melhores estratégias de profilaxia e controle da enfermidade. $O$ estudo de amostras provenientes de diversas espécies de animais silvestres terrestres procedentes de uma área de Mata Atlântica nativa no litoral Norte do Estado de São Paulo, se apresentou como uma excelente oportunidade para a pesquisa do vírus da raiva nessas espécies animais na região. Este estudo pesquisou a presença de anticorpos contra o vírus da raiva por meio do Teste Rápido de Inibição de Foco de Fluorescência (RFFIT), Microteste Simplificado de Inibição da Fluorescência (SFIMT) e Ensaio Imunoenzimático (ELISA) em amostras de soro de animais capturados em uma área de construção de um condomínio residencial e transpostos e monitorados em uma área de soltura. E ainda a detecção do vírus da raiva por meio das técnicas de Imunofluorescência Direta (IFD), Inoculação Intracerebral em Camundongos (IC) e Reação em Cadeia pela Polimerase precedida de transcrição (RT-PCR) em amostras de sistema nervoso central dos animais encontrados mortos na região. A porcentagem de amostras reagentes observada foi de $10,8 \%$ no RFFIT (considerada como "padrão ouro" para a deteç̧ão de anticorpos neutralizantes contra o vírus da raiva), 34,0\% no SFIMT e 1,13\% no ELISA. Todos as amostras submetidas as técnicas de IFD, IC e RT-PCR apresentaram resultados negativos. Os resultados observados são um evidência de circulação do vírus entre as espécies silvestres (especialmente gambás, macacos-prego e quatis) da área estudada. Estes resultados comprovam a importância de constantes estudos objetivando o entendimento e o monitoramento do papel de espécies silvestres na circulação e transmissão do vírus da raiva no Brasil. Assim como a relevância de pesquisas direcionadas a um melhor entendimento, padronização e validação das diferentes técnicas diagnósticas; levando em especial consideração a grande e única variedade de espécies animais presente em nosso país.

Palavras-chave: Raiva. Diagnóstico. Sorologia, Epidemiologia. Mamíferos Silvestres. Brasil. 


\begin{abstract}
ARAUJO, D.B. Epidemiologic study of rabies virus in wild mammals from a release area, North coast of São Paulo State, Brazil. 2012, 104p. Ph. D. Thesis (Biotecnology). Instituto de Ciências Biomédicas, Universidade de São Paulo, São Paulo, 2012.

Rabies is a zoonotic viral disease that causes thousands of humans and animals deaths each year worldwide. The emergent importance of the disease in wild animals, bats and terrestrial mammals, demonstrates the importance of epidemiological studies regarding rabies virus in those animal species, aiming the development of better strategies of prevention and control of the disease. The use of samples from several wild species from a native Rainforest area in the North coast of São Paulo State Brazil, was an excellent opportunity for the research of rabies virus circulation among wildlife in the region. The aim of the present study was the research of anti-rabies antibodies in those animals using the "Rapid Fluorescent Focus Inhibition Test - RFFIT, Simplified Fluorescent Inhibition Microtest - SFIMT and Enzime Linked Immunosorbent Assay - ELISA techniques. And also by rabies virus detection using Fluorescent Antibody Test (FAT), Mouse Inoculation Test (MIT) and Polymerase Chain Reaction by Reverse-Transcriptase (RT-PCR) in central nervous system samples from animals found dead in the area. The percentage of reagent samples observed was $10,8 \%$ on RFFIT ("gold standard" for detection of rabies virus neutralizing antibodies), $34,0 \%$ on SFIMT e $1,13 \%$ on ELISA. All samples tested by the FAT, MIT and RT-PCR techniques presented negative results. The observed results are an evidence of rabies virus circulation between the wild animal species (mainly opossuns, capuchin-monkey and coati) in the studied area. This result indicates the importance of continuous research regarding a better knowledge of the role presented by wild animals in rabies circulation and transmission in Brazil. Epidemiologic studies in different regions of the country could provide valuable information to the prevention and control of the disease. And also researches aiming the padronization and validation of the different diagnostic serologic techniques, especially when considering the great and unique variety of animals present in our country.
\end{abstract}

Key words: Rabies. Diagnosis. Serology. Epidemiology. Wild mammals. Brazil. 


\section{LISTA DE ILUSTRAÇÕES}

Figura 01 - Desenho esquemático do vírus da raiva

Figura 02 - Localização da cidade de Bertioga no litoral Norte do Estado de São Paulo, Brasil.

Figura 03 - Localização de área de construção de condomínio e 36 Fazenda Acaraú no litoral norte do Estado de São Paulo, Brasil.

Figura 04 - Armadilhas tipo "Tomahawk" para capturas de animais silvestres em área de Mata Atlântina nativa, litoral Norte do Estado de São Paulo, Brasil.

Figura 05 - "Cevas" para captura de animais silvestres em área de Mata Atlântica nativa, litoral Norte do Estado de São Paulo, Brasil.

Figura 06 - Leitura de "microchip" em gambá (Didelphis aurita) em área da Mata Atlântica nativa no litoral Norte do Estado de São Paulo, Brasil.

Figura 07 - Aplicação de "microchip" em gambá (Didelphis aurita) em área de Mata Atlântica nativa no litoral Norte do Estado de São Paulo, Brasil.

Figura 08 - Realização de biometria em gambá (Didelphis aurita) em área de Mata Atlântica nativa no litoral Norte do Estado de São Paulo, Brasil.

Figura 09 - Realização de pesagem em gambá (Didelphis aurita) em área de Mata Atlântica nativo no litoral Norte do Estado de São Paulo, Brasil.

Figura 10 - Local de captura e de soltura de gambá (Didelphis aurita) em área de Mata Atlântica nativa no litoral Norte do Estado de São Paulo, Brasil.

Figura 11 - Local de captura e de soltura de gambá (Didelphis aurita) na Fazenda Acaraú no litoral Norte de Estado de São Paulo, Brasil.

Figura 12 - Centro de manejo da Fazenda Acaraú, área de soltura de Mata Atlântica nativa no litoral Norte do Estado de São Paulo, Brasil.

Figura 13 - Coleta de sangue de tamanduá (Tamandua tetradactyla) em área de soltura no litoral Norte do Estado de São Paulo, Brasil.

Figura 14 - Soltura de tamanduá (Tamandua tetradactyla) em área de soltura no litoral Norte do Estado de São Paulo, Brasil. 
Figura 15 - Realização de necropsia para obtenção de SNC em rato silvestre (Oligoryzomys nigripes) em área de soltura no litoral Norte do Estado de São Paulo, Brasil.

Figuras 16 e 17 - Realização de necropsia por meio de tecnia de acesso 43 pelo "foramen magno" para obtenção de SNC em rato silvestre (Oligoryzomys nigripes) em área de soltura no litoral Norte do Estado de São Paulo, Brasil.

Figura 18 - Esquema de divisão de placa de SFIMT para detecção de anticorpos neutralizantes para o vírus da raiva.

Figura 19 - Esquema de divisão de placa de RFFIT para detecção de anticorpos neutralizantes para o vírus da raiva.

Figura 20 - Esquema de divisão de placa de ELISA BioProß para detecção de anticorpos contra o vírus da raiva.

Figura 21 - Distribuição, segundo a ordem animal, de mamíferos silvestres capturados em área de Mata Atlântica nativa no litoral Norte do Estado de São Paulo, Brasil.

Figura 22 - Distribuição segundo a espécie de mamíferos silvestres de mamíferos capturados em área de soltura de Mata Atlântica nativa no litoral Norte do Estado de São Paulo, Brasil.

Figura 23 - Distribuição segundo a espécie de mamíferos silvestres de mamíferos capturados no local de construção de condomínio em área de Mata Atlântica nativa no litoral Norte do Estado de São Paulo, Brasil.

Figura 24 - Total de mamíferos silvestres capturados na área FA e RSL em área de Mata Atlântica nativa no litoral Norte do Estado de São Paulo, Brasil, nos períodos de 06/2009 a 05/2011 e 06/2009 a 10/2011.

Figura 25 - Distribuição de acordo com o gênero de mamíferos silvestres capturados nas áreas FA e RSL em área de Mata Atlântica nativa no litoral Norte do Estado de São Paulo, Brasil.

Figura 26 - Distribuição de acordo com a idade de mamíferos silvestres capturados nas áreas FA e RSL em área de Mata Atlântica nativa no litoral Norte do Estado de São Paulo, Brasil.

Figura 27 - Placa de ELISA realizada para a detecção de anticorpos contra o vírus da raiva em mamíferos silvestres provenientes de área de Mata Atlântica nativa no litoral Norte do Estado de São Paulo, Brasil.

Quadro 01 - Identificação, espécie, gênero, idade e resultado dos testes de SFIMT, RIFFT e ELISA para a detecção de anticorpos contra o vírus da raiva em mamíferos silvestres provenientes de área de Mata Atlântica nativa no litoral Norte do Estado de São Paulo, Brasil. 
Figura 28 - Divisão de acordo com a ordem animal de mamíferos silvestres encontrados mortos em área de Mata Atlântica nativa no litoral Norte do Estado de São Paulo, Brasil.

Figura 29 - Amplificação por meio da RT-PCR de amostras de SNC em mamíferos silvestres provenientes área de Mata Atlântica nativa no litoral Norte do Estado de São Paulo, Brasil, para detecção da região $16 S$ do RNA extraído.

Figura 30 - Amplificação por meio da RT-PCR de amostras de SNC 78 mamíferos silvestres provenientes de área de Mata Atlântica nativa no litoral norte do Estado de São Paulo para detecção de fragmento da sequência de codificação da Nucleoproteína do vírus da raiva. 


\section{LISTA DE TABELAS}

Tabela 01 - Nome, posição no N-gene, polaridade e sequência dos "primers" utilizados para detecção do RNA do vírus da raiva em mamíferos silvestres provenientes de área de Mata Atlântica nativa no litoral Norte do Estado de São Paulo, Brasil.

Tabela 02 - Relação segundo a ordem animal e local de captura de mamíferos silvestres capturados em área de Mata Atlântica nativa no litoral Norte do Estado de São Paulo, Brasil.

Tabela 03 - Resultados da SFIMT em mamíferos silvestres provenientes de área de Mata Atlântica nativa no litoral Norte do Estado de São Paulo, Brasil.

Tabela 04 - Resultados SFIMT, segundo a espécie animal, em mamíferos silvestres provenientes de área de Mata Atlântica nativa no litoral Norte do Estado de São Paulo, Brasil.

Tabela 05 - Resultados da SFIMT, segundo a área de captura, em mamíferos silvestres provenientes de área de Mata Atlântica nativa no litoral Norte do Estado de São Paulo, Brasil.

Tabela 06 - Resultados da SFIMT, segundo o gênero, em mamíferos silvestres provenientes de área de Mata Atlântica nativa no litoral Norte do Estado de São Paulo, Brasil.

Tabela 07 - Resultados SFIMT, segundo a idade, em mamíferos silvestres provenientes de área de Mata Atlântica nativa no litoral Norte do Estado de São Paulo, Brasil.

Tabela 08 - Resultados do RFFIT (identificação, animal, espécie, sexo e idade) em mamíferos silvestres provenientes de área de Mata Atlântica nativa no litoral Norte do Estado de São Paulo, Brasil.

Tabela 09 - Resultados do RFFIT, segundo o local de captura, em mamíferos silvestres provenientes de área de Mata Atlântica nativa no litoral Norte do Estado de São Paulo, Brasil.

Tabela 10 - Resultados do RFFIT, segundo o gênero, em mamíferos silvestres provenientes de área de Mata Atlântica nativa no litoral Norte do Estado de São Paulo, Brasil.

Tabela 11 - Resultados do RFFIT, segundo a idade, em mamíferos silvestres provenientes de área de Mata Atlântica nativa no litoral Norte do Estado de São Paulo, Brasil. 
Tabela 12 - Resultados da SFIMT, segundo os resultados do RFFIT, para a detecção de anticorpos neutralizantes para o vírus da raiva em mamíferos silvestres provenientes de área de Mata Atlântica nativa no litoral Norte do Estado de São Paulo, Brasil.

Tabela 13 - Quantidade, nome comum e espécie de amostras de SNC mamíferos silvestres provenientes de área de Mata Atlântica no litoral Norte do Estado de São Paulo, submetidos a IFD, IC e RT-PCR para a detecção do vírus da raiva. 


\section{LISTA DE ABREVIATURAS E SIGLAS}

- AcNs: Anticorpos Neutralizantes

- BHK-21: Baby Hamster Kidney Cells

- CVS-11: Vírus Desafio Padrão (do inglês: Challenge Virus Standard)

- DEPEC: Dietilpirocarbonato

- DNA: Ácido Desoxirribonucleico (do inglês: Desoxy Nucleic Acid)

- ELISA: Enzime Linked Immunosorbent Assay

- FAVN: Teste de Soroneutrallização em Células (do inglês: Fluorescent Antibody Virus Neutralization)

- FFD 50 : Dose formadora de foco de fluorescência em $50 \%$ de células

- IBAMA: Instituto Brasileiro do Meio Ambiente e dos Recursos Naturais Renováveis

- IC: Inoculação Intracerebral em Camundongos

- ICTV: Comitê de Taxonomia Viral (do inglês: International Comittee on Taxonomy of Viruses)

- IFD: Imunoflurescência Direta

- OIE: Organização Mundial de Sanidade Animal

- PA: Ultra Pura

- pb: Pares de Bases

- PBS: Solução Salina Tamponada

- PCR: Reação em Cadeia pela Polimerase

- RFFIT: Teste Rápido de Inibição de Foco da Fluorescência (do inglês: Rapid Fluorescent Inhibiton Test)

- RNA: Ácido Ribonucléico (do inglês: Ribonucleic Acid)

- RT-PCR: Reação em Cadeia pela Polimerase precedida de transcrição

- SFIMT: Microteste simplificado de inibição da fluorescência (do inglês: Simplified Fluorescent Inhibition Microtest for the Titration of Rabies Neutralizing Antibodies)

- UI: Unidades Internacionais

- WHO: Organização Mundial da Saúde (do inglês: World Health Organization). 
1 INTRODUÇÃO 18

2 REVISÃO BIBLIOGRÁFICA 20

3 OBJETIVOS

3.1 Objetivo geral

$\begin{array}{ll}3.2 \text { Objetivo específico } & 34\end{array}$

4 MATERIAL E MÉTODOS 35

4.1 Amostras $\quad 35$

4.1.1 Captura de Animais $\quad 35$

4.1.2 Colheita de Amostras 40

4.2 Microteste simplificado de inibição da fluorescência - 43 "simplified fluorescent inhibition microtest for the titration of rabies neutralizing antibodies" - SFIMT

4.3 Teste rápido de inibição de foco da fluorescência ("Rapid Fluorescent Focus Inhibition Test') - RFFIT

4.4 Ensaio imunoenzimático ("Enzime Linked Immunosorbent Assay" - ELISA)

4.5 Prova de Imunofluorescência Direta (IFD) 49

4.6 Inoculação Intracerebral em Camundongos (IC) 50

4.7 Reação em cadeia pela polimerase precedida de transcrição 50 (RT-PCR)

4.8. Análise Estatística

5. RESULTADOS 54

5.1 Animais capturados $\quad 54$

5.2 Microteste simplificado de inibição da fluorescência - 59 "Simplified fluorescent inhibition microtest for the titration of rabies neutralizing antibodies" - SFIMT 
5.3 Teste Rápido de Inibição de Foco da Fluorescência - "Rapid

Fluorescent Focus Inhibition Test" - RFFIT

5.4 Comparação entre o Microteste simplificado de inibição da

fluorescência - SFIMT e o Teste Rápido de Inibição de Foco de Fluorescência - RFFIT

5.5 Ensaio Imunoenzimático ("Enzime Linked Immunosorbent Assay" - ELISA)

5.6 Imunofluorescência Direta - IFD, Inoculação Intrecerebral em Camundongos - IC e Reação em Cadeia pela Polimerase precedida de transcrição- RT- PCR.

6 DISCUSSÃO

7 CONCLUSÕES

REFERÊNCIAS

ANEXOS 


\section{INTRODUÇÃO}

A raiva é uma enfermidade de origem viral, sintomatologia nervosa e praticamente $100 \%$ de letalidade. Ocorre em mais de 150 países e territórios, apresenta caráter zoonótico e é responsável anualmente por cerca de 55.000 mortes e 10 milhões de tratamentos pós-expositivos de seres humanos em todo o mundo (WORLD HEALTH ORGANIZATION, 2011).

No Brasil, o controle do ciclo urbano da raiva, por meio de campanhas de vacinação de cães e gatos e demais ações de vigilância e controle da enfermidade, associado as modificações ambientais provocadas pela intervenção humana permitiram a identificação de diferentes espécies animais atuando como reservatório e transmissoras do vírus; além da observação de um aumento no número de diagnósticos e acidentes com espécies anteriormente identificadas. Os casos de raiva em seres humanos decorrentes de acidentes com espécies silvestres (morcegos hematófagos, sagüis e carnívoros terrestres) nas regiões Norte e Nordeste do país e a notificação de casos de morcegos positivos para a enfermidade encontrados em áreas urbanas da região Sudeste comprovam este fato. Os estudos da raiva envolvendo espécies silvestres no Brasil podem fornecer informações valiosas para a determinação das variantes virais envolvidas e os possíveis reservatórios, permitindo o desenvolvimento e a implementação de métodos de profilaxia e controle da raiva eficientes.

A Mata Atlântica constitui o bioma mais rico em biodiversidade do planeta, possui $1.300 .000 \mathrm{~km}^{2}$ atinge $15 \%$ do território nacional englobando 17 Estados Brasileiros, incluindo o de São Paulo. Somado a magnitude desse números, um outro dado modifica a percepção sobre a imensidão desse bioma: cerca de $93 \%$ de sua formação original já foi devastada. Obviamente, a maior ameaça ao já precário equilíbrio desta biodiversidade é justamente a ação humana e a pressão de sua ocupação e os impactos de sua atividade( SOS Mata Atlântica, 2012).

Para a construção de um condomínio no município de Bertioga, em uma área de Mata Atlântica nativa no litoral Norte do Estado de São Paulo foi realizada a transposição de espécies de fauna e flora para uma área de soltura de animais silvestres no mesmo município (Fazenda Acaraú). As atividades de transposição foram realizadas com autorização do Instituto Brasileiro e dos Recursos Naturais IBAMA para as atividades de transposição e para o projeto de pesquisa em questão. 
A captura, manejo e o estudo de impacto ambiental realizados em diversas espécies de mamíferos silvestres se apresentaram como uma excelente oportunidade para a pesquisa da possível presença do vírus da raiva na região e determinação das espécies animais envolvidas; especialmente por se tratar de uma situação única, onde foi possível comparar uma área de mata atlântica com ocorrência de desmatamento e uma área de conservação ambiental. Essa pesquisa foi realizada por meio da identificação de anticorpos contra o vírus da raiva nos animais destinados à transposição e nos animais monitorados na área de soltura, além da pesquisa do antígeno viral em amostras de sistema nervoso central provenientes dos animais encontrados mortos nas duas áreas. 


\section{REVISÃO BIBLIOGRÁFICA}

A raiva é uma enfermidade zoonótica de etiologia viral com ocorrência em todos os continentes com exceção da Antártida, entretanto, mais de 95\% das mortes de humanos em decorrência da doença ocorre na Ásia e África (WHO, 2011). No Brasil a enfermidade é considerada endêmica em todo o território, com registro de diferentes níveis de ocorrência nas diferentes regiões e Estados (BRASIL, 2010).

Considerada uma das mais antigas enfermidades noticiadas em humanos, sua correlação com a mordida de "cachorros loucos" é relatada no código de Eshmuna na Babilônia no século 24 a.C. (RUPPRECHT; HANLON; KOPROWSKI, 2002) sendo que somente no século 19 obteve-se a confirmação do modo de transmissão, período em que Louis Pasteur desenvolveu a primeira vacina contra a raiva por meio da obtenção do vírus fixo por atenuação do vírus de rua (KOPROWSKI, 1995).

O agente etiológico é um RNA vírus pertencente ao gênero Lyssavirus, família Rhabdoviridae (PRINGLE, 1991). Apresenta forma cilíndrica (projétil) com diâmetro de $75 \mathrm{~nm}$ e comprimento de $180 \mathrm{~nm}$, revestido por um envelope constituído de uma membrana lipoproteíca apresentando projeções de glicoproteína viral (WOLDEHIWET, 2002). A Figura 01 apresenta o esquema do vírus da raiva.

Figura 01 - Desenho esquemático do vírus da raiva. São Paulo, junho de 2012

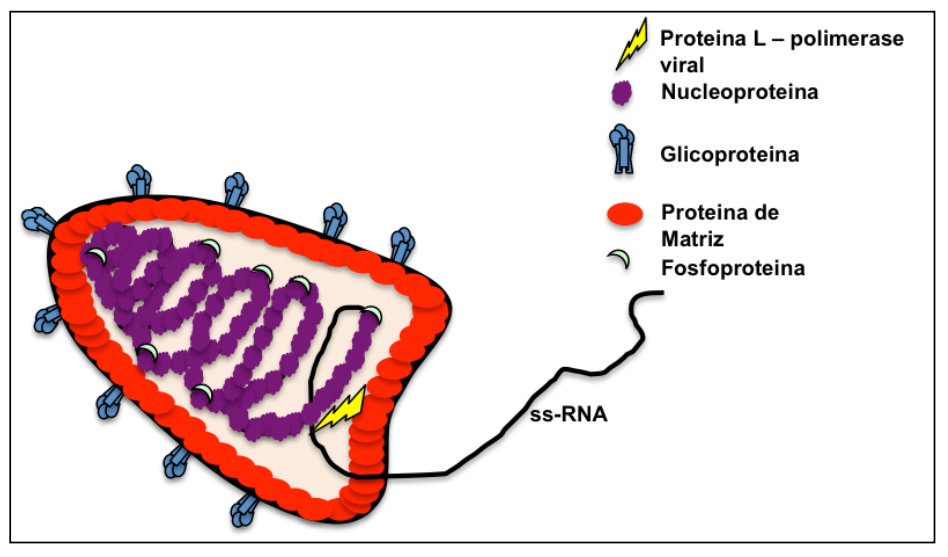

Fonte: Campos (2011) 
O vírus da raiva apresenta RNA de fita simples, linear, não segmentado e com polaridade negativa. O genoma viral possui aproximadamente 12 Kb (11932 nucleotídeos) compreendendo cinco genes responsáveis por codificar cinco diferentes proteínas, na ordem N, P, M, G e L da extremidade 3' para a 5' (TORDO et al., 1986a).

A Nucleoproteína $(\mathrm{N})$ possui 450 aminoácidos e apresenta maior a similaridade de sequência de aminoácidos entre as diferentes espécies virais, porém, possui diversidade nucleotídica em uma pequena região (BOURHY; KISSI; TORDO, 1993), é essencial para a propagação viral e um importante alvo para diagnóstico (KOPROWSKI, 1995).

A Fosfoproteína (P) possui 297 aminoácidos e atua como um co-fator da polimerase durante a transcrição e replicação viral (TORDO et al., 1986a).

A Polimerase (L) possui 2142 aminoácidos sendo responsável pelas atividades enzimáticas necessárias para a transcrição do RNA e replicação viral (TORDO et al., 1986a).

O envelope viral é composto por uma bicamada lipídica a qual estão associadas duas proteínas, a proteína de membrana M e a glicoproteína G.

A Proteína de Membrana (M) possui 202 aminoácidos e atua na ligação entre o envelope e o nucleocapsídeo (TORDO et al., 1986b).

A Glicoproteína $(G)$ possui 524 aminoácidos e é a única transmembranária (TORDO et al., 1986b). É responsável pela fixação da partícula viral aos receptores celulares, participa da endocitose viral e é responsável pela indução da produção de anticorpos neutralizantes e da imunidade celular (COX; DIETSCHOLD; SCHNEIDER, 1977; GAUDIN et al., 1991).

De acordo com o Comitê de Taxonomia Viral (ICTV - "International Commitee on Taxonomy of Viruses") o gênero Lyssavirus encontra-se dividido em 12 espécies virais, denominadas anteriormente de genótipos:

- espécie Rabies Virus (genótipo 01): compreende as amostras clássicas do vírus da raiva, amostras selvagens Espécie Rabies Virus (genótipo 01): compreende as amostras clássicas do vírus da raiva, amostras selvagens isoladas de animais e as amostras vacinais, também denominadas como fixas.

As demais espécies compreendem os vírus da raiva relacionados: 
- espécie Lagos Bat Virus (genótipo 02): identificada em morcegos frugívoros na África subsaariana com eventuais contaminações de outras espécies de mamíferos.

- espécie Mokola Virus (genótipo 03): identificada em roedores, musaranhos, cães, gatos e crianças na África subsaariana.

- espécie Duvenhage Virus (genótipo 04): identificada em morcegos insetívoros na África subsaariana.

- espécies European Bat Lyssaviruses - EBL1 e EBL2 (genótipos 05 e 06): identificada em morcegos insetívoros na Europa.

- espécie Australian Bat Lyssavirus (genótiopo 07): identificada em morcegos insetívoros na Austrália.

- espécie Aravan Virus: identificada em morcegos insetívoros na Ásia Central.

- espécie Khujand Virus: identificada em morcegos insetívoros na Ásia Central.

- espécie Irkut Virus: identificada em morcego insetívoro na Sibéria

- espécie West Caucasian Bat Virus: identificada em morcego insetívoro no Sudeste europeu (ICTV, 2009; KUZMIN et al. 2010).

Uma nova espécie de Lyssavirus - Shimoni bat virus - foi isolada em morcegos no Quênia (KUZMIN et al., 2010).

As sete primeiras espécies virais do gênero são consideradas patogênicas para mamíferos, incluindo o homem, resultando em uma infecção aguda do sistema nervoso central (BOURHY; KISSI; TORDO, 1993). As demais espécies não foram identificadas como transmissoras da enfermidade para humanos (KUZMIN et al., 2010).

Todos os mamíferos são susceptíveis ao vírus da raiva, em especial os das ordens Carnivora e Chiroptera. Os cães são os principais transmissores da enfermidade a humanos e responsáveis pelo chamado ciclo terrestre da raiva (RUPPRECHT, 2002). A realização de campanhas de vacinação de cães e gatos permitiu o controle deste ciclo em várias regiões do mundo, incluindo o Brasil. A eficiência das campanhas de prevenção e controle do ciclo urbano possibilitou a queda no número de casos em cães, com conseqüente queda de sua transmissão e a possibilidade da eliminação desta forma de transmissão da doença na América Latina (BELOTTO et al., 2005; SCHNEIDER et al., 2007). 
No ciclo silvestre, as espécies que atuam como reservatórios e são responsáveis por eventuais infecções de outras espécies variam de acordo com a região em todo o mundo. Na Europa o principal animal responsável por este ciclo é a raposa vermelha (Vulpes vulpes); morcegos não hematófagos, "racoons" - guaxinins (Procyon lotor), "skunks" - cangambás (Spilogale gracilis e Mephitis mephitis), raposa cinza (Urocyon cinereoargenteus) e a raposa vermelha estão associados a forma silvestre da enfermidade na América do Norte. Na América do Sul, a principal espécie animal associada ao ciclo silvestre e ao ciclo aéreo, são os morcegos hematófagos da espécie Desmodus rotundus (WOLDEHIWET, 2002).

Os morcegos hematófagos são os responsáveis pela transmissão da enfermidade para animais de criação acarretando em perdas econômicas (ARELLANO-SOTA, 1988), caracterizando-se também como importantes transmissores da raiva a humanos no continente Sul-Americano (CASTILHO et al., 2010; DE MATTOS et al., 1999; ROSA; KOTAIT; BARBOSA, 2006; WARNER et al., 1999).

Enquanto o número de casos em cães, e conseqüentemente os casos de raiva em humanos em decorrência de acidentes com esta espécie, apresenta queda, o ciclo silvestre continua apresentando importância no Brasil. No ano de 2010 foram registrados 17 casos de raiva em cães, 200 em morcegos não hematófagos, 30 em canídeos silvestres, além de casos em morcegos hematófagos e primatas (BRASIL, 2011).

Os surtos de raiva ocorridos nos Estados do Pará e Maranhão em 2004 e 2005 foram relacionados a agressões por Desmodus rotundus (BRASIL, 2005; ROSA; KOTAIT; BARBOSA, 2006). Esta espécie de quiróptero foi responsável por $45 \%$ dos casos de raiva em humanos no país de 2000 a 2011 , contra $12 \%$ dos casos de 1990 a 1999 (BRASIL, 2011). A ocorrência da enfermidade nesses animais, especialmente sem o controle adequado, pode resultar no acometimento de diversas espécies animais e até mesmo humanos, além de acarretar em grandes prejuízos econômicos (DE MATTOS et al.,1999; ROMJIN; VAN DER HEIDE; CATTANEO, 2003; SCHAEFER et al., 2002).

O vírus da raiva foi identificado em 41 espécies diferentes de morcegos no Brasil, compreendendo 25 gêneros e 03 famílias - Phyllosomidade (43,9\%), Vespertilonidae (29,3\%) e Molossidae (26,8\%). Dentre estas 41 espécies, 03 são hematófagas, Desmodus rotundus, Diphylla ecaudata e Diaemus youngii e as 
restantes compreendem principalmente morcegos insetívoros e frugívoros (SODRÉ; GAMA; ALMEIDA, 2010).

Embora os morcegos hematófagos sejam os principais agentes do ciclo aéreo, o vírus da raiva já foi isolado em espécies não hematófagas de morcegos no Brasil (ALBAS et al., 2011; CUNHA et al., 2006; FAVI et al., 2002; LANGONI et al., 2005; QUEIROZ et al., 2012), inclusive em áreas urbanas (CABRAL et al., 2012; FERRAZ; ACHKAR; KOTAIT, 2007; INSTITUTO PASTEUR, 2011; SILVA et al., 2007). Até o momento, entretanto, não foram registrados casos de raiva decorrentes de agressões por essas espécies no Brasil (BRASIL, 2011).

Os morcegos se apresentem como os principais reservatórios e transmissores da forma silvestre da raiva no Brasil, entretanto, outras espécies de animais selvagens atuam na epidemiologia da enfermidade, sendo inclusive responsáveis pelo acometimento de seres humanos e outras espécies animais (FAVORETTO et al., 2001; 2006).

Os primatas constituem a terceira espécie responsável pela transmissão da enfermidade a humanos no país (BRASIL, 2011; RAMOS; RAMOS, 2002). No Brasil o sagüi da espécie Callithrix jaccus jaccus foi responsável por 16 casos em humanos de 1990 a 2011 nos Estados do Ceará e Piauí (BRASIL, 2011). Animais desta espécie são altamente adaptáveis e comumente mantidos como animais de companhia na região Nordeste e em outras regiões do país. Em um estudo realizado por Favoretto et al. em 2001, estes animais foram identificados como responsáveis por manter um ciclo epidemiológico único e independente da enfermidade transmitido diretamente a humanos.

Primatas da espécie Cebus apella - Macaco-prego foram diagnosticados com a enfermidade (BRASIL, 2011). Animais desta espécie são extremamente adaptáveis em relação aos hábitos alimentares e habitat, e são encontrados em áreas urbanas com conseqüente contato com humanos (CATÃO-DIAS, 2006; RYLANDS et al., 2001;).

Canídeos silvestres também estão relacionados ao ciclo silvestre da enfermidade, no ano de 2010 foram registrados 26 casos da enfermidade em espécies de canídeos silvestres, todos na região Nordeste (BRASIL, 2011). Entre os anos de 1980 e 2011 foram registrados 15 casos de raiva em humanos em decorrência de acidentes com essas espécies, sendo que o último caso ocorreu em 1993 no Estado de Pernambuco (BRASIL, 2011). 
Dentre as espécies de canídeos silvestres da fauna brasileira, o Cachorro do Mato (Cerdocyon thous) e a Raposa do Mato (Pseudalopex vetulus) foram identificados como os principais reservatórios e transmissores da raiva (CARNIELI et al., 2006). Adicionalmente, os cachorros do mato foram identificados como reservatórios e transmissores de uma linhagem genética do vírus da raiva também isolada de guaxinim (Procyon cancrivorous) e humano (FAVORETTO et al., 2006).

No Estado de São Paulo, as campanhas de vacinação e de controle de populações de cães e gatos contribuíram para o controle da raiva urbana. O último caso de raiva em seres humanos relacionado a variante mantida por cães registrado no Estado data do ano de 1997; e em 2001 foi registrado o último caso relacionado a variante mantida por morcegos hematófagos (LAZARINI, 2006). O último caso em cães registrado no Estado, assim como da variante viral relacionada a esta espécie animal, foi registrado no ano de 1998 (QUEIROZ et al., 2012). Apesar do controle do ciclo urbano, o ciclo aéreo continua relevante, no ano de 2011 foram registrados 46 casos em bovinos, 05 casos em eqüinos (decorrentes de acidentes com morcegos hematófagos) e 54 casos em morcegos não-hematófagos no Estado (INSTITUTO PASTEUR, 2011).

A transmissão da enfermidade ocorre principalmente por meio do contato com a saliva de animais contaminados através de mordeduras ou arranhaduras. $O$ contágio pode ainda ocorrer por meio de inalação de partículas virais (JOHNSON; PHILLPOTTS; FOOKS, 2006; WARREL, 1995); transplantes de órgãos provenientes de doadores contaminados com o vírus (DIETZCHOLD; KOPROWSKI, 2004) e pela ingestão de carcaças de animais contaminados (CHARLTON; CASEY, 1979; RANSDEN; JOHNSON, 1975).

A adsorção viral ocorre por meio da ligação da glicoproteína viral a um ou mais receptores específicos na membrana celular (WUNNE, REAGAN, KOPROWSKI, 1984). Após a fixação o vírus penetra na célula hospedeira por endocitose e libera a ribonucleoproteína no citoplasma. O RNA viral é transcrito em moléculas complementares positivas sequencialmente da extremidade 3' em direção a extremidade 5', produzindo primeiro um RNA leader e depois cinco RNAs mensageiros, que correspondem às proteínas $N, P, M, G, e L$. Em seguida, há uma segunda etapa replicativa, na qual as fitas positivas servirão de molde para a produção de fitas negativas, as quais serão encapsidadas (BANERJEE, 1987). A liberação das partículas virais ocorre por brotamento nos sítios da membrana 
celular, onde as proteínas do envelope viral se acumularam previamente (WUNNER, 2007).

O vírus da raiva é altamente neurotrópico; após a inoculação viral, ocorre replicação inicial nos tecidos periféricos no local de inoculação, ocorrendo então a disseminação para o sistema nervoso central por transporte axoplasmático pelos nervos periféricos, principalmente motores. Uma vez no sistema nervoso central, ocorre intensa replicação e disseminação viral e então migração centrífuga para diversos órgãos, incluindo as glândulas salivares (JACKSON, 2007).

O período de incubação é variável e em humanos pode ser de meses ou anos em casos extremos. Acredita-se que o vírus pode persistir em latência ou em níveis muito baixos de replicação no tecido muscular (JOHNSON; CUNNINGHAM; FOOKS, 2010).

Nos primeiros estágios da infecção os vírus inoculados na pele e músculos podem ativar uma pequena resposta imune adaptativa antes de sua entrada no SNC. Uma vez no SNC a resposta imume ao vírus dificilmente ocorrerá em decorrência de fatores como: a falta de estruturas linfóides e células apresentadoras de antígenos no SNC; a capacidade das variantes patogênicas de evasão da resposta imune primária; a imunossupressão observada em neurônios infectados e a impermeabilidade da barreira hemato-encefálica a anticorpos (LAFON, 2007).

A produção de anticorpos derivada da resposta imune humoral aos antígenos virais é controlada por inúmeros fatores, incluindo a quantidade presente de antígeno, a forma e local da inoculação e o estado de saúde do indivíduo (MOORE; HANLON, 2010). Os anticorpos são produzidos em decorrência da ativação dos linfócitos B e são importantes por atuarem logo nos primeiros estágios da infecção (SMITH, 1981). A maior parte dos anticorpos específicos contra o vírus da raiva é direcionada a epítopos da glicoproteína viral, embora anticorpos anti-nucleoproteína tenham sido reconhecidos, ainda que sem atividade neutralizante (MOORE; HANLON, 2010).

Adicionalmente a ativação da resposta imune humoral ocorre ainda a ativação da resposta imune celular por meio dos linfócitos $T$ auxiliares $\left(\mathrm{CD}_{4}{ }^{+}\right)$, responsável pela eliminação direta do vírus ou de células infectadas (CELIS et al., 1985).

O diagnóstico da raiva está relacionado com a tomada de decisões cruciais para evitar a morte de seres humanos. A detecção viral pós-morten em animais suspeitos de expor humanos ao risco de contrair a enfermidade permite a aplicação 
de medidas profiláticas pós-exposição prevenindo a progressão fatal da infecção ou ainda medidas desnecessárias em casos negativos. A utilização das técnicas diagnósticas com finalidades epidemiológicas também são de extrema importância paro o conhecimento da ocorrência e formas de transmissão da enfermidade em animais domésticos e selvagens; permitindo a aplicação de medidas mais eficientes para a prevenção e controle da enfermidade (TRIMARCHI; NADIN-DAVIS, 2007).

A identificação de corpúsculos de inclusão citoplasmáticos nas células nervosas de animais infectados, os Corpúsculos de Negri, foi a primeira técnica utilizada para o diagnóstico da raiva. Porém esta técnica apresenta sensibilidade limitada, com detecção das inclusões em $50 \%$ a $80 \%$ das amostras positivas (SMITH, 1996).

A WHO recomenda os métodos de Imunofluorescência Direta (IFD) e de Inoculação Intrecerebral em Camundongos (IC) ou isolamento viral em culturas celulares para a detecção do vírus em amostras suspeitas de sistema nervoso central. A IC deve ser realizada em paralelo com a IFD e a técnica de imunofluorescência deve ser ainda utilizada para a confirmação dos resultados positivos da IC (WHO, 2011).

A prova de Imunofluorescência Direta foi desenvolvida em 1950 por Conns e Kaplan e modificada para o diagnóstico da raiva em 1958 por Goldwasser e Kissling. Por ser um teste rápido, sensível e específico, a IFD é considerada a técnica "padrão ouro" para o diagnóstico da enfermidade (DEAN; ABELSETH; ATANASIU, 1996; ORGANISATION MONDIALE DE LA SANTÉ ANIMALE, 2009; WHO, 2011).

Um único teste com resultado negativo não descarta a possibilidade de infecção, por isso, a IFD deve ser realizada simultaneamente com a inoculação do material suspeito, por via intracerebral (IC), em camundongos de 3 a 4 semanas de idade (OIE, 2009). O método de IC foi desenvolvido por Webster e Dawson em 1935 e é capaz de detectar pequenas quantidades do vírus da raiva, permitindo seu isolamento para posteriores estudos. $O$ isolamento viral em culturas celulares, como células de neuroblastoma de camundongos (N2A), pode ser utilizado com a mesma finalidade (RUDD; TRIMARCHI, 1989).

A ausência de sinais clínicos e lesões patognomônicas da raiva tornam o diagnóstico laboratorial essencial. Em razão da soroconversão tardia, usualmente concomitante ao aparecimento dos sintomas, e da taxa de mortalidade de quase $100 \%$ a partir desta fase as provas sorológicas não são usuais para diagnóstico 
ante-mortem. Porém, estes testes são essenciais para a mensuração da resposta vacinal e podem ainda indicar a ocorrência de circulação viral em uma determinada população (MOORE, CHANDRA e BRIGGS, 2007; OIE, 2009).

As técnicas para detecção de anticorpos ("gold standard") recomendadas pela WHO (2011) e OIE (2009) são o Teste Rápido de Inibição de Foco da Fluorescência ("Rapid Fluorescent Focus Inhibition Test" - RFFIT) e o Teste de Soroneutralização em Células (Fluorescent Antibody Virus Neutralization - FAVN), as quais detectam anticorpos neutralizantes - AcNs - para o vírus da raiva.

Descrita primeiramente em 1973 por Smith et al., o RFFIT permitiu a substituição da detecção de AcNs em camundongos utilizada até então, sendo adaptado para placas em 1979 por Zalan et al. A técnica consiste na detecção de AcNs pela observação da redução do número de focos fluorescentes em células infectadas pelo vírus (SMITH; YAEGER; BAER, 1996).

A técnica de FAVN utiliza o mesmo princípio de neutralização viral da RFFIT, porém com um sistema "tudo ou nada" na observação da neutralização com resultados equivalentes aos observados no RFFIT (BRIGGS et al., 1998; CLIQUET; AUBERT; SAGNE, 1998).

As provas sorológicas são utilizadas para detecção de resposta adequada a vacinação de forma a permitir o transporte e o comércio internacional de animais domésticos (OIE, 2009) e para o monitoramento da vacinação oral em animais silvestres (FEHLNER-GARDINER et al., 2012; NEUBERT et al., 2001).

A detecção de anticorpos contra o vírus da raiva permite ainda estudos de circulação viral em uma determinada área e/ou população animal. Embora os dados sorológicos descrevam apenas em parte a situação epidemiológica da raiva na população, eles fornecem subsídeos para essa análise. A presença de anticorpos em animais não vacinados sugere fortemente que o vírus da raiva circule em uma determinada região e população animal (ROSATTE; GUNSON, 1984).

Anticorpos neutralizantes para o vírus da raiva foram detectados em populações de morcegos em animais aparentemente saudáveis, como em diversas espécies, principalmente frugívoros, no Brasil (ALMEIDA et al., 2011); morcegos da espécie Desmodus rotundus no Brasil (ALMEIDA et al., 2005); morcegos insetívoros Tadarida brasiliensis (TURMELLE et al.,2010); espécies não-hematófagas no México (SALAS-ROJAS et al., 2004) e insetívoras Eptesicus furinalis nos EUA (SHANKAR et al., 2002). 
A resposta imune ao vírus da raiva foi também detectada em populações de diversas espécies de mamíferos terrestres aparentemente saudáveis e sem registros de vacinação. Anticorpos neutralizantes foram observados em morcegos, raposas e guaxinins na Argentina (LORD et al., 1975); raposas nos EUA (CAREY; McLEAN, 1978; MILLER et al., 2000); guaxinins - "racoons" nos EUA (BIGLER et al., 1983; HILL; BERAN; CLARK., 1992; JENKINS; PERRY; WINKLER, 1988); cangambás "skunks" no Canadá (ROSATTE; GUNSON, 1984); cachorros selvagens na Tanzânia (GAYSCONE et al., 1993); hienas no Serengeti (EAST et al., 2001); gatodo mato na Bolívia (DEEM; DAVIS; PACHECO, 2004); mink na França (PHILIPPA et al., 2008); javalis na Eslovênia (VENGUST et al., 2011) e chacais na Namíbia (BELLAN et al., 2012)

O microteste simplificado de inibição de foco da fluorescência ("Simplified fluorescent inhibition microtest for the titration of rabies neutralizing antibodies" SFIMT) desenvolvido por Favoretto et al. em 1993; é comumente utilizado no Brasil em razão da maior facilidade de execução e resultados equivalentes ao RFFIT para o monitoramento da reposta vacinal em humanos (BATISTA et al., 2011; CHAVES et al., 2006). O SFIMT tem sido utilizado no país para a detecção de AcNs em mamíferos silvestres com bons resultados, tanto para a verificação de eficácia de vacinação (PASSOS; GERMANO; FEDULLO, 2002) como em animais de vida livre provenientes de áreas sem registro de vacinação (JORGE et al., 2010; MEGID, 2000;).

Poucos estudos de detecção de anticorpos contra o vírus da raiva foram realizados com mamíferos silvestres, especialmente os terrestres, no Brasil até o momento. Almeida et al., 2001, utilizaram o RFFIT para a detecção de anticorpos neutralizantes em diversas espécies de animais silvestres provenientes da cidade de São Paulo encontrando uma prevalência de $14 \%$ de animais positivos, sugerindo a circulação do vírus da raiva entre esses animais na região.

Megid em 2000, utilizou a técnica de SFIMT em veados na espécie Blastocerus dichotomus (cervo do pantanal) da região Oeste do Estado de São Paulo detectando positividade de 13,4\%.

Jorge et al., 2010, realizaram a detecção de anticorpos contra o vírus da raiva por meio do SFIMT em carnívoros silvestres provenientes do Centro-Oeste brasileiro e encontraram uma positividade de $12,3 \%$. 
Machado et al., 2011, detectaram AcNs para o vírus da raiva em 11,11\% de macacos pregos (Cebus apella nigritus) de vida livre provenientes de área de conservação no Sudeste do país utilizando o RFFIT.

Outras técnicas de detecção de anticorpos contra o vírus da raiva foram desenvolvidas, como o Ensaio Imunoenzimático ("Enzime Linked Immunosorbent Assay" - ELISA), o qual detecta a presença de anticorpos contra o vírus da raiva, incluindo aqueles que não apresentam ação neutralizante. Este teste apresenta como vantagens a detecção e quantificação de anticorpos em menor tempo, sem a necessidade de manipulação de vírus infectante quando comparadas a técnicas de detecção de anticorpos neutralizantes como RFFIT e FAVN (BARTON e CAMPBELL, 1988; SERVAT et al., 2008). O teste foi comparado com as técnicas de RFFIT e FAVN para a detecção de anticorpos em humanos (FEYSSAGUET et al., 2007); animais domésticos (CLIQUET et al., 2004; WASNIEWSKI; CLIQUET, 2011); em mamíferos silvestres vacinados (CLIQUET et al., 2003; FEHLNER-GARDINER et al., 2012;) e em espécies silvestres provenientes de áreas sem utilização de vacinação (MORK et al., 2011).

Para a detecção de anticorpos em soros de animais silvestres, o ELISA apresenta ainda a vantagem de não depender de cultivo celular, considerando-se que muitas vezes as amostras apresentam contaminantes que provocam toxicidade celular em função de características das diferentes espécies e das dificuldades observadas durante a coleta do material (MOORE et al., 2007). Embora as técnicas de neutralização viral devam ser preferencialmente utilizadas para o monitoramento de vacinação, o ELISA podem ser utilizado em casos de citotoxicidade decorrente de baixa qualidade do soro; considerando-se que o "kit" a ser utilizado seja validado para as espécies em questão (OIE, 2009).

As técnicas de biologia molecular, em especial a Reação em Cadeia pela Polimerase (PCR) permitem a detecção e amplificação de sequências específicas do genoma de um microorganismo, ainda que o agente se encontre em quantidades muito pequenas na amostra ou não esteja viável (BELÁK; BALLAGI-PORDÁNY, 1993).

A técnica de Reação em Cadeia pela Polimerase precedida de trancrição (RTPCR) demonstrou ser eficiente para o diagnóstico da raiva em amostras de sistema nervoso central em decomposição, mesmo quando as técnicas de IFD e IC 
apresentaram resultados negativos (ARAUJO et al., 2008; FAVORETTO et al., 2005).

Os produtos amplificados nas técnicas de biologia molecular podem ser ainda utilizados para a caracterização dos genótipos e de variantes virais (ALBAS et al., 2011; ARAI et al., 1997; BLACK et al., 2000; CARNIELI et al., 2006 FAVORETTO et al., 2001; 2006; KISSI; TORDO; BOURHY, 1995; HEINEMANN et al., 2002; OLIVEIRA et al., 2010; QUEIROZ et al., 2012).

A capacidade do vírus de produzir uma infecção praticamente não detectada pela resposta imune adaptativa até o estágio final da enfermidade e de evasão da resposta imune que ocorre são os motivos para a fatalidade de enfermidade em praticamente $100 \%$ dos casos. Em contraste, a vacinação é capaz de estimular altos níveis de anticorpos neutralizantes, motivo pelo qual a vacinação em indivíduos expostos e não vacinados apresenta grande importância e efetividade (MOORE; HANLON, 2010).

Em razão da necessidade de impedir a entrada do vírus no SNC, a prevenção da enfermidade é baseada na vacinação pré e pós-exposição e administração de soro hiperimune em indivíduos expostos (WHO, 2011).

As vacinas utilizadas em humanos e animais domésticos utilizam variantes virais inativadas contendo proteínas inteiras. As vacinas contendo variantes atenuadas do vírus e as vacinas recombinantes são utilizadas para a imunização de animais silvestres (LAFON, 2007).

A primeira vacina contra o vírus da raiva para humanos foi desenvolvida por Louis Pasteur com o vírus atenuado em medula de coelhos. Dando início a utilização das chamadas vacinas de primeira geração para a prevenção da enfermidade. Essas vacinas eram provenientes de tecido nervoso de animais adultos e apresentam grandes quantidades de mielina muitas vezes acarretando em severas complicações neurológicas nos indivíduos imunizados (MESLIN; KAPLAN, 1996).

Os acidentes neurológicos foram reduzidos com o advento da vacina Fuenzalida- Palacios em 1955, produzida a partir de cérebros de camundongos recém-nascidos, com presença quase nula de mielina (MESLIN; KAPLAN, 1996).

As vacinas denominadas como de segunda geração são obtidas a partir de cultivo viral em ovos embrionados de galinhas e patas e submetidas a purificação. Estas vacinas apresentam boa imunogenicidade, segurança, baixos custos de 
produção e permitiram a evolução da produção de vacinas a partir de cultivo celular (GLUCK, 1996).

As vacinas de terceira geração são produzidas a partir de culturas celulares adaptadas a propagação do vírus da raiva, resultando em vacinas altamente purificadas, com elevada potência e segurança; apresentando a desvantagem dos custos mais altos de produção em decorrência da manutenção das linhagens celulares e dos vírus. Essas vacinas são as mais utilizadas atualmente para imunização de humanos (NICHOLSON, 1996).

A utilização de iscas contendo vacinas obtidas com vírus atenuados para o controle da raiva em raposas vermelhas foi demonstrada nos Estados Unidos e Canadá no final dos anos 60 , sendo esta forma de vacinação rapidamente empregada na imunização oral de raposas na Europa a partir dos anos 70 (BLANCOU; MESLIN, 1996). As campanhas de imunização oral permitiram a eliminação da raiva em raposas vermelhas em diversos países do continente europeu. A vacinação oral foi também utilizada com bons resultados no Canadá, embora o vírus ainda persista neste país em decorrência da variante viral relacionada a "skunks" (Mephitis mephitis). Nos Estados Unidos esta forma de vacinação é utilizada em populações de "raccoons" (Procyon lotor), coyotes e raposas cinzas (Urocyon cinereoargentus) e também com a finalidade de prevenir o reaparecimento da raiva canina (SLATE et al., 2009).

As vacinas mais recentes são obtidas a partir de subunidades virais; como as vacinas recombinantes, onde a proteína $\mathrm{G}$ do vírus da raiva é expressa em variantes virais como o Vaccinia virus. A vacina VRG ("Vaccinia-rabies glycoprotein recombinant oral vaccine"), onde a glicoproteína viral da variante fixa do vírus da raiva ERA (Evelyn Rokitniki Abelseth) é expressada, é utilizada para a imunização por via oral de animais silvestres como "raccoons" e outros carnívoros (DREESEN, 2007; RUPPRECHT et al., 1996).

A Organização Mundial da Saúde recomenda a aplicação de soro hiperimune contra o vírus da raiva de origem eqüina ou humana associado a vacinação nos tratamentos pós-exposição em humanos, conforme a gravidade dos ferimentos (WHO, 2011).

O controle da raiva depende principalmente da prevenção da enfermidade por meio de campanhas de vacinação em cães e gatos em áreas endêmicas e do controle da movimentação destes animais para áreas consideradas livres da 
enfermidade nestas espécies; além da adoção de medidas efetivas para eliminação ou redução do vírus e de sua circulação em reservatórios silvestres (WOLDEHIWET, 2002). No Brasil não é realizada a vacinação de animais silvestres, mas é realizada a vigilância passiva por meio da identificação viral em animais encontrados mortos em estradas e rodovias; além de ações de treinamento em vigilância e manejo de animais silvestres (BRASIL, 2011). Adicionalmente, ações de educação em saúde e controle de populações de cães a gatos são de extrema importância; assim como informações referentes a espécies silvestres, como nunca manusear diretamente morcegos e demais espécies, especialmente quando estiverem caídos no chão ou encontrados em situações não habituais (BRASIL, 2011b) . 


\section{OBJETIVOS}

\subsection{Objetivo geral}

- Conhecer a situação epidemiológica da raiva por meio da pesquisa de antígeno e anticorpo do vírus em animais silvestres provenientes de uma área de Mata Atlântica nativa no litoral Norte de Estado de São Paulo, Brasil.

\subsection{Objetivos específicos}

- Pesquisar a presença de anticorpos contra o vírus da raiva em diversas espécies de mamíferos silvestres terrestres provenientes de área de desmate para construção de um condomínio e de uma área de soltura para monitoramento dos animais nativos e/ou transpostos.

- Utilizar as técnicas de Microteste simplificado de inibição da fluorescência ("Simplified Fluorescent Inhibition Microtest" - SFIMT), Teste Rápido de Inibição de Foco da Fluorescência ("Rapid Fluorescent Focus Inhibition Test” - RFFIT) e Ensaio Imunoenzimático ("Enzime Immonosorbent Assay"- ELISA), quanto a sua sensibilidade e especificidade para a detecção de anticorpos contra o vírus da raiva em animais silvestres provenientes da área em questão.

- Pesquisar a ocorrência do vírus da raiva em mamíferos silvestres encontrados mortos na área por meio das técnicas de Imunofluorescência Direta (IFD), Inoculação Intracerebral em Camundongos (IC) e Reação em Cadeia pela Polimerase precedida de transcrição (RT-PCR). 


\section{MATERIAL E MÉTODOS}

\subsection{Amostras}

\subsubsection{Captura de animais}

As amostras utilizadas foram provenientes da área de construção de um condomínio residencial e da Fazenda Acaraú, ambos localizados no município de Bertioga no litoral Norte do Estado de São Paulo e pertencentes a Mata Atlântica nativa e com espécies de fauna e flora características deste bioma. A fazenda é uma área de soltura inserida no Parque Estadual da Serra do Mar onde são realizadas as atividades de transposição de fauna e flora, monitoramento e avaliação de impacto ambiental das espécies de flora e fauna retiradas da área de desmatamento para construção do condomínio (Figuras 02 e 03).

As atividades de transposição apresentaram autorização do IBAMA, tanto para a Empresa Gaia de Consultoria Ambiental (responsável pelas atividades e parceira deste projeto de pesquisa) quanto para o projeto em questão (Autorização IBAMA número 15486-1) (Anexo A).

Figura 02- Localização da cidade de Bertioga (ponto A) no litoral Norte do Estado de São Paulo, Brasil. Junho de 2012

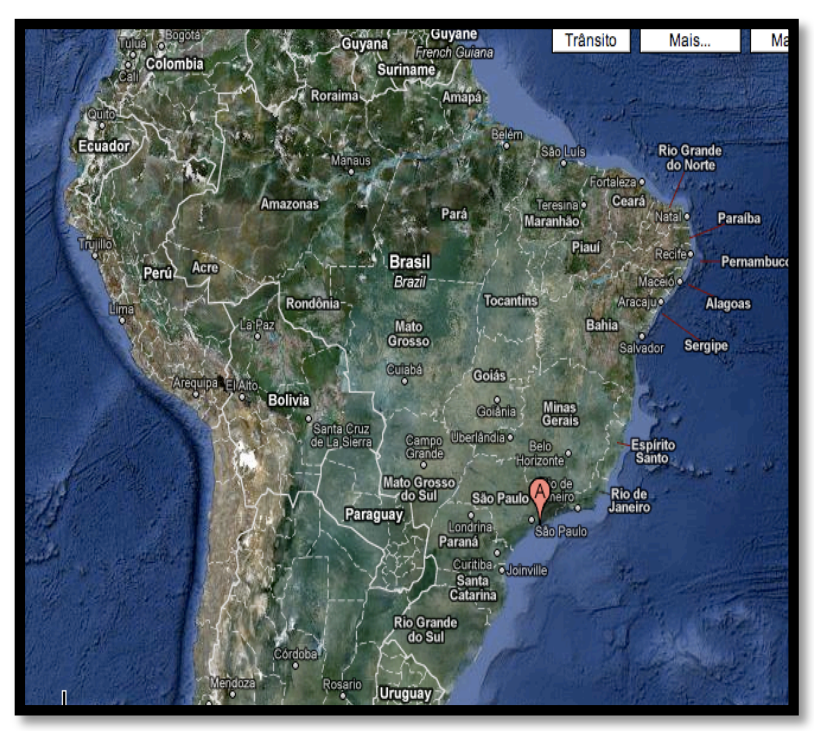

Fonte: Google (2012) 
Figura 03- Localização das áreas de RSL e FA no litoral norte do Estado de São Paulo, Brasil. Junho de 2012

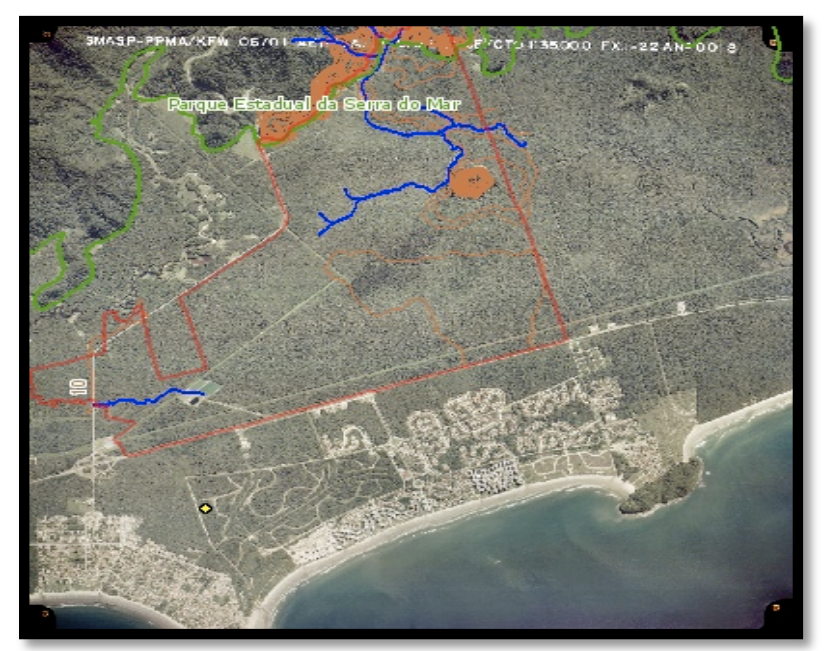

RSL: Riviera de São Lourenço (área fora das linhas parte inferior da figura) FA: Fazenda Acaraú (delimitada pela linha vermelha)

Fonte: Gaia (2011)

As capturas foram realizadas de duas formas. Na primeira os animais foram capturados na área de desmatamento e transpostos para a área de soltura da Fazenda Acaraú. A segunda foi realizada rotineiramente na própria fazenda para monitoramento dos animais transpostos, com a finalidade de verificação do possível impacto causado pela transposição desses animais (assim como o impacto em todo o bioma alterado); os animais foram capturados, avaliados e soltos na própria área da fazenda.

Os animais foram capturados utilizando-se armadilhas do tipo "Tomahawk" (Figura 04). As armadilhas foram preparadas no final do dia (Figura 05) e a captura realizada na manhã seguinte. 
Figura 04 - Armadilhas tipo "Tomahawk" preparadas para captura de mamíferos silvestres em área de Mata Atlântica nativa no litoral Norte do Estado de São Paulo, Brasil. São Paulo, junho de 2012

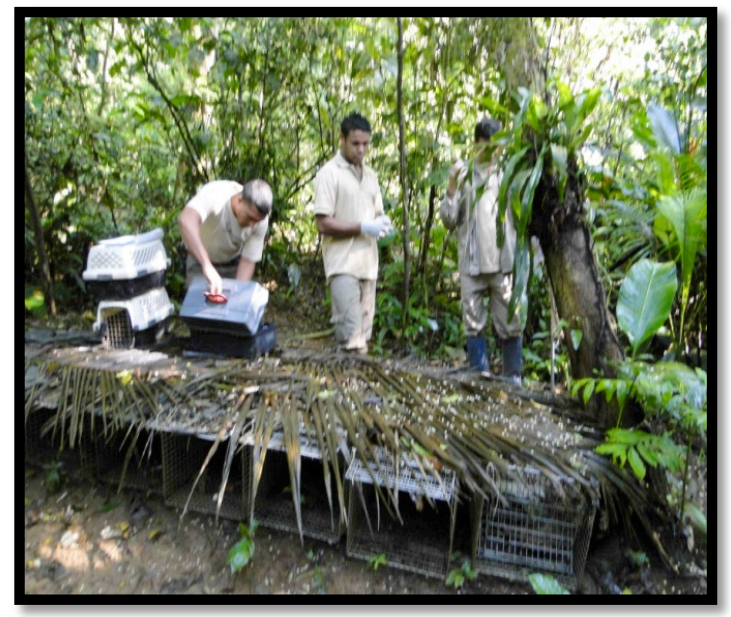

Fonte: Araujo (2012)

Figura 05-"Cevas" para captura de animais silvestres em área de Mata Atlântica nativa, litoral Norte do Estado de São Paulo, Brasil. Junho de 2012

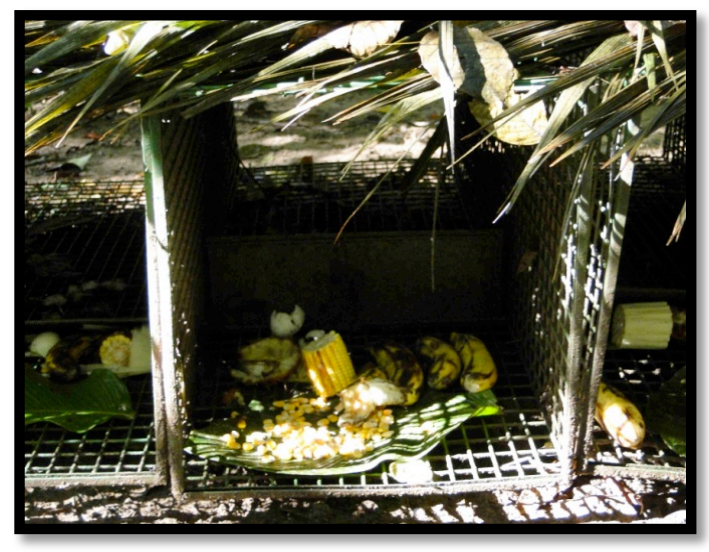

Fonte: Araujo (2012)

Os animais capturados foram contidos por meio da utilização de puçás e cambões e sempre utilizando-se equipamentos de proteção individual (EPIs) apropriados. Primeiramente foi utilizado leitor de microchips (Figura 06) com a finalidade de verificar se o animal foi submetido a uma recaptura. Os animais sem microchip (de primeira captura) foram identificados (Figura 07), e todos os animais capturados (primeira captura e recapturas) foram submetidos a biometria; com pesagem, medição e determinação de sexo e idade (estimativa), além da observação de possíveis alterações físicas e/ou comportamentais (Figuras 08 e 09). 
Figura 06 - Leitura de microchip para detecção de recaptura em gambá (Didelphis aurita) em área de Mata Atlântica nativa no litoral Norte do Estado de São Paulo, Brasil. Junho de 2012

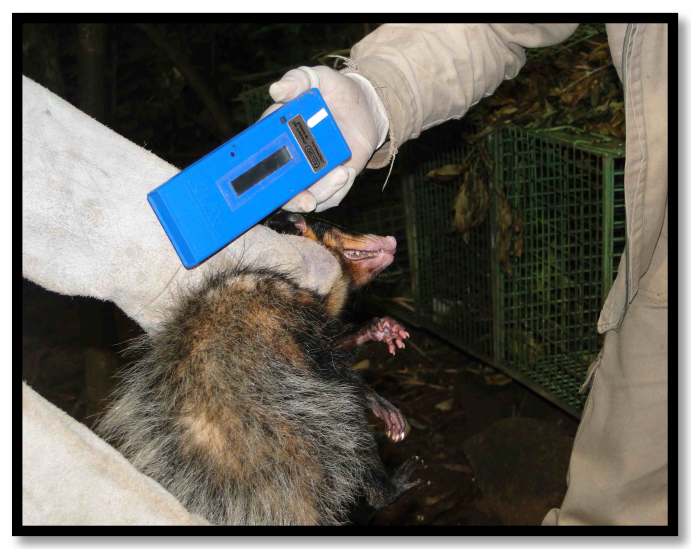

Fonte: Araujo (2012)

Figura 07- Aplicação de microchip em (gambá) Didelphis aurita capturado em área de Mata Atlântica nativa no litoral Norte do Estado de São Paulo, Brasil. Junho de 2012

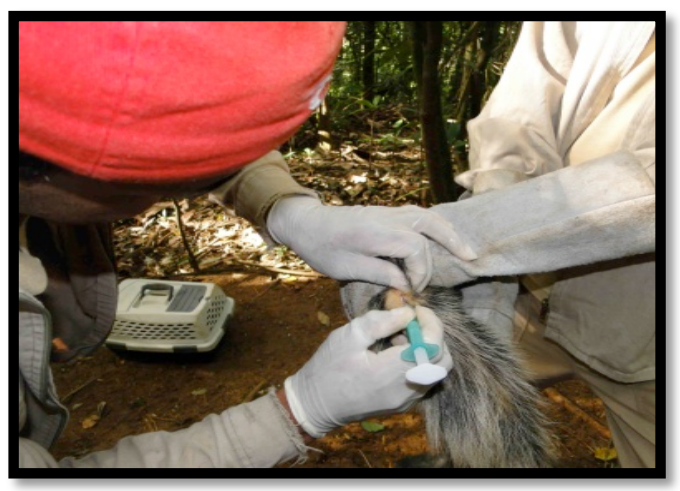

Fonte : Araujo (2012)

Figura 08- Realização de biometria em gambá (Didelphis aurita) em área de Mata Atlântica nativa no litoral Norte do Estado de São Paulo, Brasil. São Paulo, junho de 2012

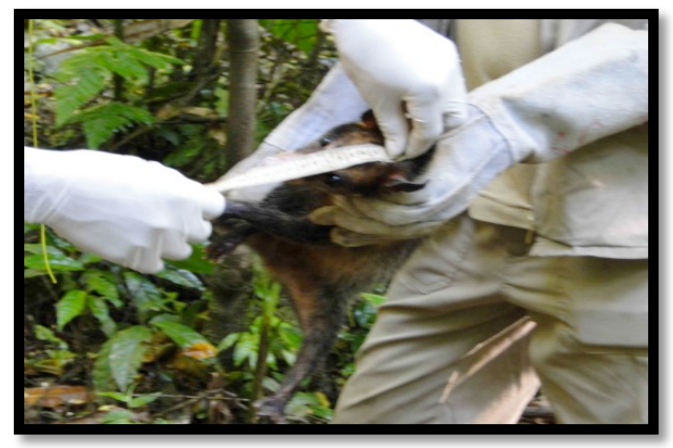

Fonte : Araujo (2012) 
Figura 09- Realização de pesagem de gambá (Didelphis aurita) em área de Mata Atlântica nativa no litoral Norte do Estado de São Paulo, Brasil. Junho de 2012.

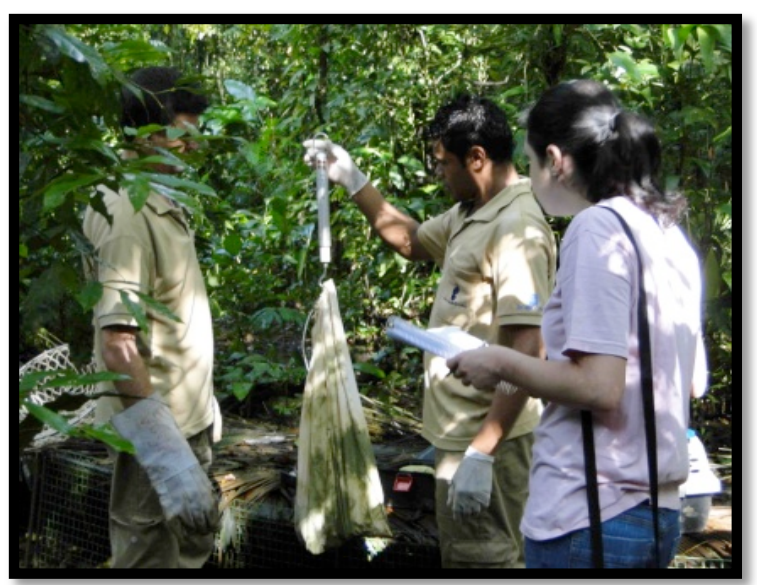

Fonte: Araujo (2012)

Todos os animais possuiam fichas onde foram armazenadas todas as informações como idade, sexo, peso, medidas de biometria - comprimento focinhocauda, comprimento do membro posterior, comprimento da cauda, comprimento focinho-crânio, comprimento total, altura da cernelha e altura da orelha - possíveis alterações encontradas, procedimentos realizados, além de fotos e mapas onde são marcado os pontos exatos de captura e soltura. (Figuras 10 e 11).

Figura 10- Local de captura e de soltura de gambá (Didelphis aurita) para transposição em área de Mata Attântica nativa no litoral Norte do Estado de São Paulo, Brasil. Junho de 2012

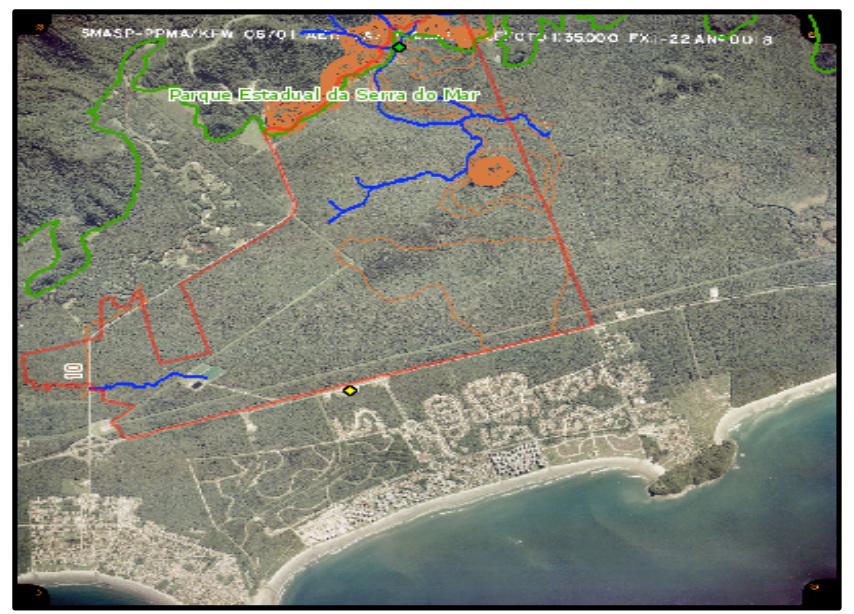

Ponto amarelo: Local de captura na área de construção de condomínio - RSL

Ponto verde: Local de soltura na Fazenda Acaraú - FA

Fonte: Gaia (2012) 
Figura 11- Local de captura e de soltura de gambá (Didelphis aurita) na Fazenda Acaraú, área de soltura no litoral Norte do Estado de São Paulo, Brasil. Junho de 2012

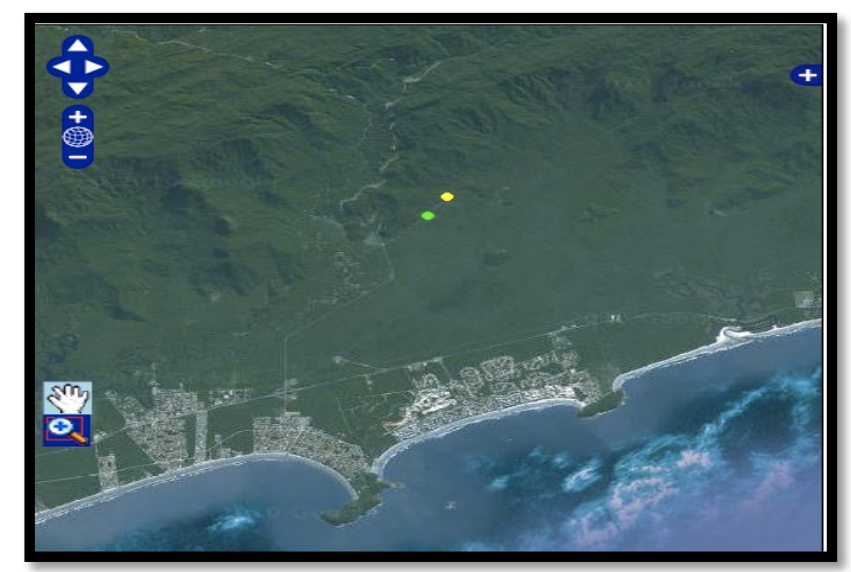

Ponto amarelo: Local de captura

Ponto verde: Local de soltura

Fonte: Gaia (2012)

\subsubsection{Colheita de amostras}

Os animais capturados pela primeira vez foram encaminhados ao centro de manejo na área da fazenda (Figura 12) onde foram realizadas as colheitas de sangue (Figura 13). Não foram realizadas coletas em animais recapturados.

Foi realizada contenção física dos animais, sem utilização de tranquilizantes, e o sangue foi obtido por meio da punção das veias femoral ou caudal. As amostras foram centrifugadas - 10 minutos em microcentrífuga ("mini-spin") - no centro de manejo para obtenção do soro, o qual foi encaminhado ao laboratório sob refrigeração (cerda de duas horas de viagem em embalagens de isopor contendo gelo reciclável) onde foram mantidas em congelamento $\left(-20{ }^{\circ} \mathrm{C}\right)$ até o momento de realização do diagnóstico.

Após a colheita de sangue foi realizada a soltura de todos os animais (Figura 14). 
Figura 12- Centro de manejo da Fazenda Acaraú, área de soltura de Mata Atlântica nativa no litoral Norte do Estado de São Paulo, Brasil. Junho de 2012

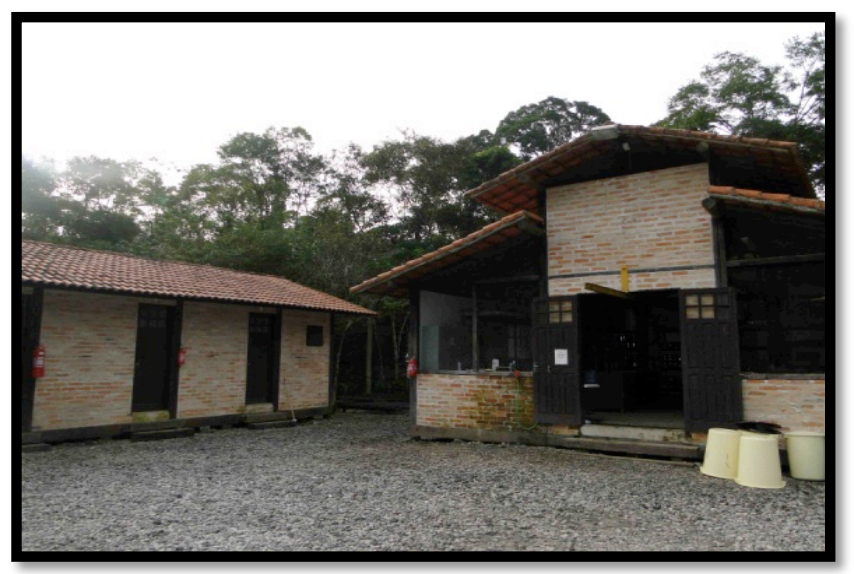

Fonte: Araujo (2012)

Figura 13- Colheita de sangue de tamanduá (Tamandua tetradactyla) em área de soltura no litoral Norte do Estado de São Paulo, Brasil . Junho de 2012

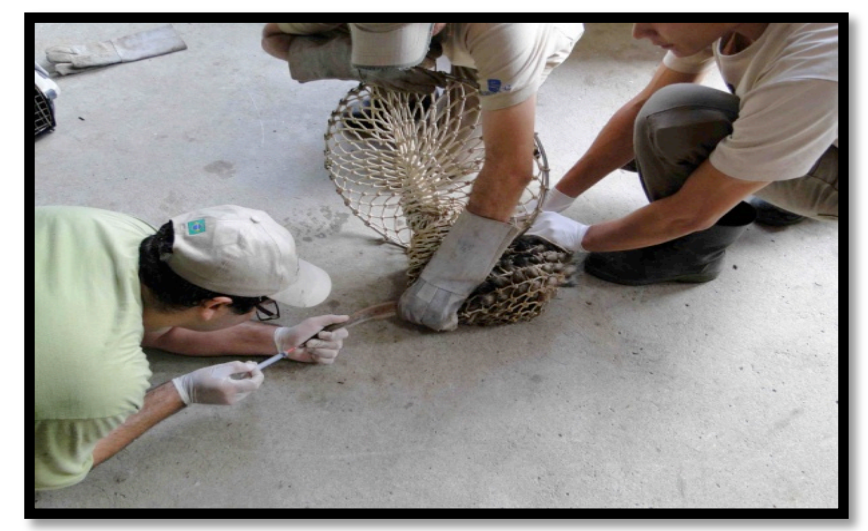

Fonte: Araujo (2012)

Figura 14 - Soltura de tamanduá (Tamandua tetradactyla) em área de soltura no litoral Norte do Estado de São Paulo, Brasil. Junho de 2012

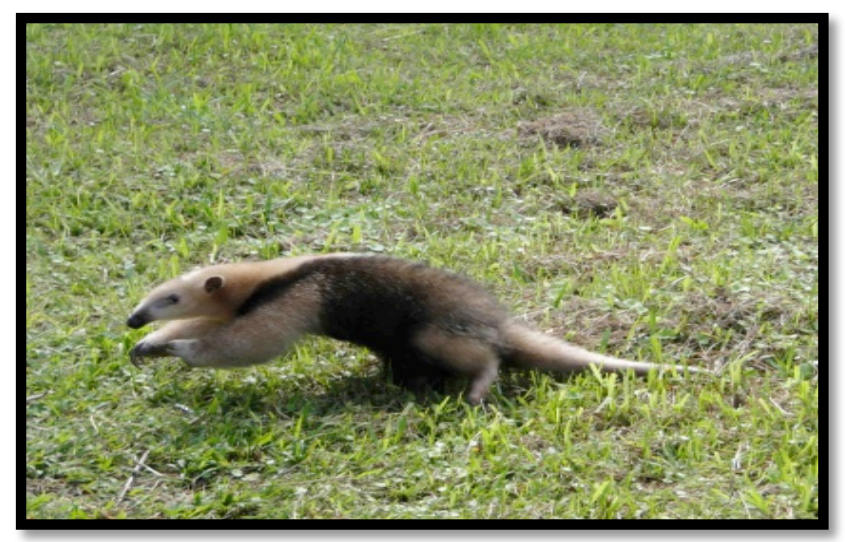

Fonte: Araujo (2012) 
Todos os animais encontrados mortos nas duas áreas, incluindo os mortos em estrada ("road kill"), foram submetidos a necrópsia (Figura 15) para obtenção de amostras de SNC.

Devido a necessidade de preservação da caixa craniana, foi utilizada a técnica de acesso ao sistema nervoso central através do foramen magno e aspiração do material descrita por lamamoto, Quadros e Queiroz em 2011 em diversos dos animais necropsiados, além da utilização da técnica clássica com abertura da caixa craniana (Figuras 16 e 17).

As amostras obtidas foram encaminhadas ao laboratório sob refrigeração (cerda de duas horas de viagem em embalagens de isopor contendo gelo reciclável) onde foram mantidas em congelamento $\left(-20^{\circ} \mathrm{C}\right)$ até o momento de realização do diagnóstico.

Figura 15- Realização de necrópsia para obtenção de SNC em rato silvestre (Oligoryzomys nigripes) em área no litoral Norte do Estado de São Paulo, Brasil. Junho de 2012

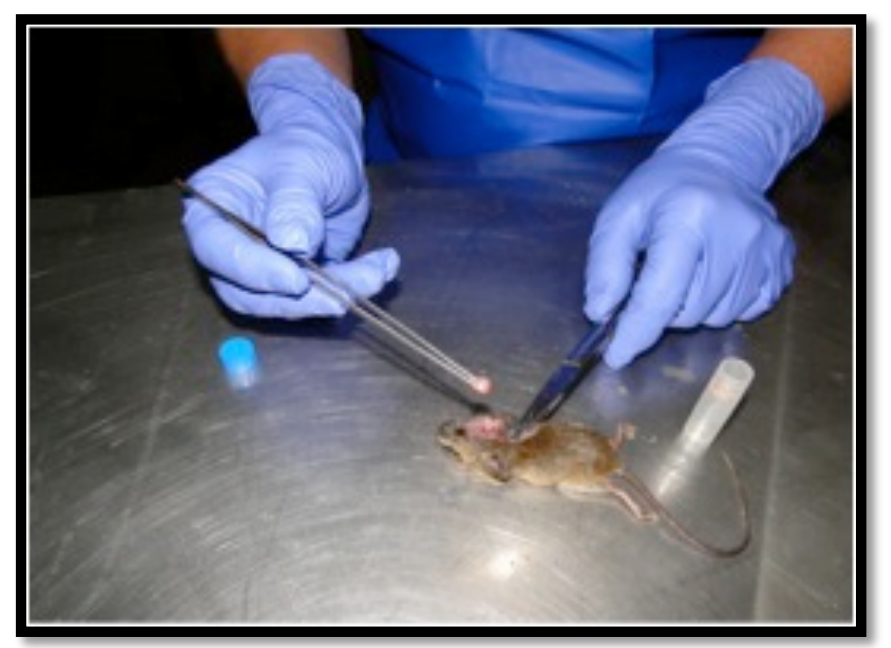

Fonte: Araujo (2012) 
Figuras 16 e 17 - Realização de necrópsia por meio da técnica de acesso pelo "foramen magno" para obtenção de amostra de SNC em rato silvestre (Oligoryzomys nigripes) na área de soltura no litoral Norte do Estado de São Paulo, Brasil. Junho de 2012
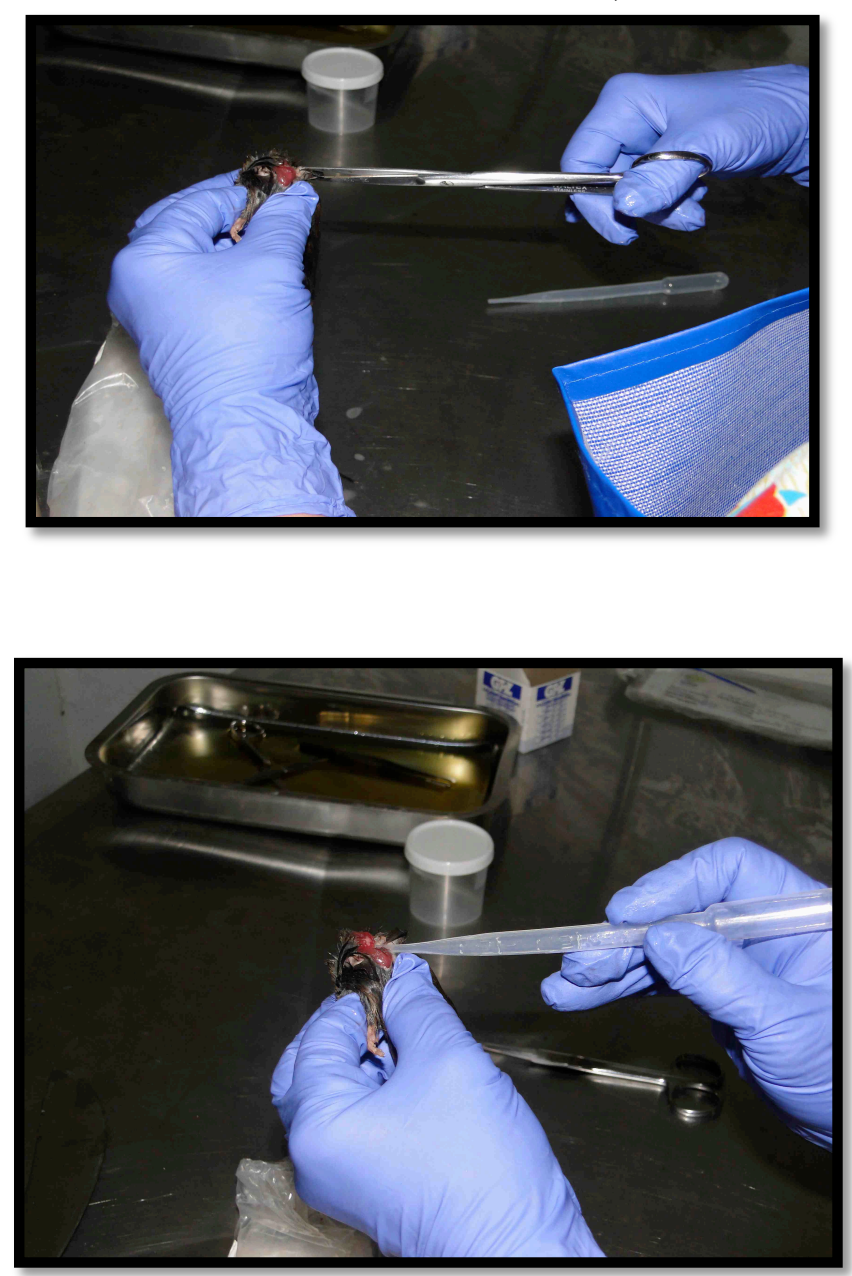

Fonte: Araujo (2012)

4.2 Microteste simplificado de inibição da fluorescência - "Simplified fluorescent inhibition microtest for the titration of rabies neutralizing antibodies" - SFIMT

A prova foi realizada no Laboratório de Raiva do Centro de Controle de Zoonoses de acordo com o protocolo descrito por Favoretto et al. em 1993 utilizando-se a variante "Challenge Virus Standard" do vírus da raiva (CVS-11) e células BHK21 - C13 ("Baby Hamster Kidney"). Foram utilizados controle positivo (pool de soros positivos) e controle negativo (pool de soros negativos) e soro controle com título conhecido aferido de acordo com soro padrão OIE. 
Após inativação a $56{ }^{\circ} \mathrm{C}$ por 30 minutos, foram realizadas quatro diluições de cada soro $(1: 5,1: 10,1: 20,1: 40)$ em microplacas de 96 poços com fundo chato. A diluição foi realizada adicionando-se $20 \mu \mathrm{L}$ de soro e $80 \mu \mathrm{L}$ de Meio Eagle para cultivo celular (acrescido de 05\% de soro fetal bovino) na primeira cavidade, nas três cavidades seqüentes foram adicionados $50 \mu \mathrm{L}$ de meio e transferidos $50 \mu \mathrm{L}$ da primeira cavidade após homogeneização com auxilio de uma pipeta automática até a quarta diluição. A figura 18 apresenta o esquema de divisão da placa utilizada.

Em seguida foram adicionados $50 \mu \mathrm{L}$ do vírus (100 FFD50) em todos os poços. Após uma hora de incubação em estufa de CO2 $5 \%$ a $37^{\circ} \mathrm{C}$, adicionou-se a suspensão de células $\mathrm{BHK} 21\left(3,7 \times 10^{5}\right.$ células $\left./ \mathrm{mL}\right)$ e então foi realizada a incubação em estufa de $\mathrm{CO} 25 \%$ a $37^{\circ} \mathrm{C}$ por 24 horas.

Para determinação da infecção celular foi realizada Imunofluorescência Direta nas placas. As células foram fixadas com $80 \mu \mathrm{L}$ de acetona PA $80 \%$ por 10 minutos a $-20{ }^{\circ} \mathrm{C}$ e foram adicionados $50 \mu \mathrm{L}$ de conjugado "Liquid anti-rabies nucleocapsid conjugate" (Bio-Rad®, Marnes-La-Coquette, France) e realizada incubação em estufa de $\mathrm{CO} 25 \%$ a $37{ }^{\circ} \mathrm{C}$ por uma hora. O conjugado foi então desprezado e realizada a lavagem por imersão das placas duas vezes em PBS e duas vezes em água destilada.

Após a secagem, foi adicionado uma gota de glicerina tamponada $(\mathrm{pH} 8,0)$ em cada poço seguida de leitura em microscópio de fluorescência. O título foi definido a partir da maior diluição com presença de $50 \%$ ou mais de células não infectadas - fluorescência negativa. O título foi determinado em Unidades Internacionais (UI) com base na comparação com o soro padrão da OIE utilizado.

Foram consideradas reagentes amostras onde foi observada a presença de anticorpos neutralizantes por meio da técnica, isto é, apresentando títulos maiores ou iguais a $0,16 U \mathrm{U} / \mathrm{mL}$. O ponto de corte foi estabelecido a partir da maior diluição onde se detectou neutralização viral; $50 \%$ ou mais de células não infectadas a partir da primeira diluição (1:5), indicando a presença de anticorpos neutralizantes na amostra, ainda que sem título protetor $(\geq 0,5 \mathrm{Ul} / \mathrm{mL})$. 
Figura 18- Esquema de placa de divisão de placa de SFIMT para detecção de anticorpos neutralizantes para o vírus da raiva. São Paulo, junho de 2012

$\begin{array}{llllllllllll}1 & 2 & 3 & 4 & 5 & 6 & 7 & 8 & 9 & 10 & 11 & 12\end{array}$

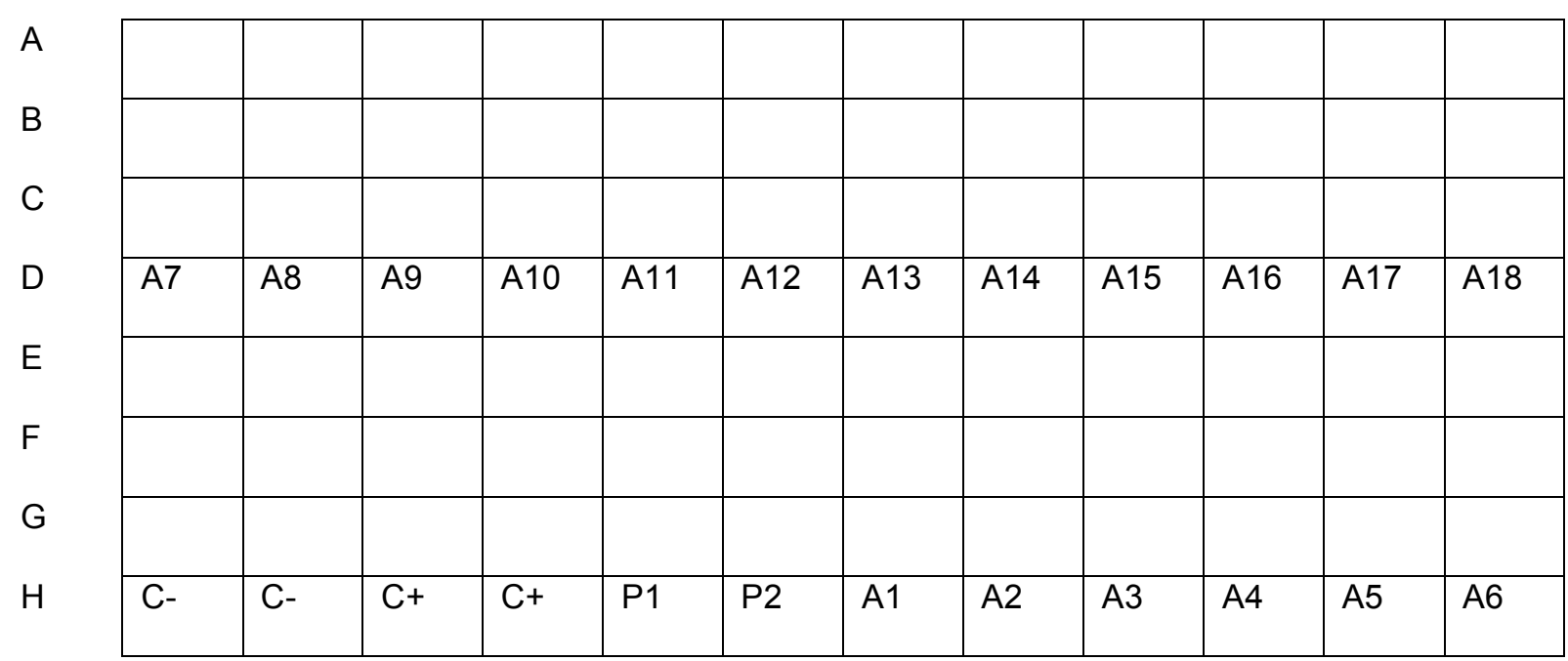

SFIMT - Técnica de soroneutralização em células simplificada

C - - Controle negativo

C+ - Controle positivo

P1 e P2 - Soros padrão OIE

A1 a A18 - Amostras a serem testadas

Fonte: Araujo (2012)

\subsection{Teste Rápido de Inibição de Foco da Fluorescência - "Rapid Fluorescent Focus Inhibition Test" - RFFIT}

O teste foi realizado no Laboratório de Raiva do Centro de Controle de Zoonoses (CCZ) de São Paulo de acordo com a técnica recomendada pela WHO (WHO, 2011), utilizando-se a variante "Challenge Virus Standard" do vírus da raiva (CVS-11) e células BHK21 - C13 ("Baby Hamster Kidney"). Foram utilizados controle positivo (pool de soros positivos) e controle negativo (pool de soros negativos) e soro controle com título conhecido aferido de acordo com soro padrão OIE.

Os soros previamente inativados a $56{ }^{\circ} \mathrm{C}$ por uma hora foram diluídos na razão 1:5 em microplacas de 96 poços. Foram adicionados $80 \mu \mathrm{L}$ de meio de cultura celular (Meio Eagle acrescido de 5\% de soro fetal bovino - MEM) e $20 \mu \mathrm{L}$ do soro a ser testado no poço da primeira diluição. Nos poços seguintes foram adicionados $50 \mu \mathrm{L}$ de meio e realizadas diluições seriadas transferindo-se $50 \mu \mathrm{L}$ de soro e meio 
do primeiro poço para o poço seguinte até a sexta diluição. A figura 19 representa o esquema da placa utilizada para realização da RFFIT.

Figura 19-Esquema da divisão de placa controle de RFFIT para detecção de anticorpos neutralizantes para o vírus da raiva. São Paulo, junho de 2012

\begin{tabular}{|c|c|c|c|c|c|c|c|c|c|c|c|}
\hline & 1 & 2 & 3 & 4 & 5 & 6 & 7 & 8 & 9 & 10 & 11 \\
\hline A & A1 & & & & & & A9 & & & & \\
\hline B & A2 & & & & & & A10 & & & & \\
\hline C & A3 & & & & & & A11 & & & & \\
\hline D & A4 & & & & & & A12 & & & & \\
\hline$E$ & A5 & & & & & & $\mathrm{C}+$ & & & & \\
\hline$F$ & A6 & & & & & & C- & & & & \\
\hline G & A7 & & & & & & $P$ & & & & \\
\hline $\mathrm{H}$ & A8 & & & & & & CVS & & & & \\
\hline
\end{tabular}

A1 a A12 - Amostras a seres testadas

C+ - Controle positivo

C- - Controle negativo

$\mathrm{P}$ - Soro padrão OIE

CVS - Vírus para titulação

Fonte: Araujo (2012)

Após as diluições foram adicionados $50 \mu \mathrm{L}$ (100 FFD $\left.{ }_{50}\right)$ de CVS-11 em todos os poços com exceção dos quatro poços correspondentes a titulação viral.

Em seguida foi realizada incubação em estufa com $5 \%$ de $\mathrm{CO} 2$ a $37{ }^{\circ} \mathrm{C}$ por uma hora. Durante a incubação foi realizada a tripsinização de uma garrafa de cultura celular contendo cultura confluente de células BHK-21, realizada contagem e diluição em MEM com a finalidade de se obter uma concentração final de $3,7 \times 10^{5}$ céls $/ \mathrm{mL}$. Foram então adicionados $50 \mu \mathrm{L}$ de suspensão celular em cada poço das duas placas. As placas foram incubadas em estufa com $5 \%$ de $\mathrm{CO} 2$ a $37^{\circ} \mathrm{C}$ por 24 horas.

Foi realizado o descarte do meio de cultura das placas e adicionados $70 \mu \mathrm{L}$ de Acetona PA a $80 \%$ e as placas fixadas a $-20{ }^{\circ} \mathrm{C}$ por 10 minutos. As placas fixadas foram então secas e adicionou-se $40 \mu \mathrm{L}$ de conjugado "Liquid anti-rabies nucleocapsid conjugate" (Bio-Rad®) em cada poço. As placas foram incubadas em 
câmara úmida em estufa a $37^{\circ} \mathrm{C}$ por uma hora. O conjugado foi desprezado seguido de lavagem por imersão das placas duas vezes em PBS e duas vezes em água destilada.

Após a secagem, foi adicionado uma gota de glicerina tamponada $(\mathrm{pH} 8,0)$ em cada poço seguida de leitura em microscópio de fluorescência. Foram contados 10 campos por poço e considerados positivos os campos com presença de fluorescência em ao menos uma célula. Os títulos foram calculados de acordo com a fórmula de Spearman-Kärber.

Foram considerados positivos os soros onde foi observada neutralização completa a partir da primeira diluição (1:5), isto é, apresentando títulos maiores ou iguais a $0,11 \mathrm{UI} / \mathrm{mL}$. Indicando presença de anticorpos neutralizantes para o vírus da raiva, ainda que com títulos inferiores ao estabelecido como protetores para humanos $(\geq 0,50 \mathrm{Ul} / \mathrm{mL})$.

\subsection{Ensaio Imunoenzimático - "Enzime Linked Immunosorbent Assay" - ELISA}

A prova de ELISA foi realizada no Laboratório de Raiva e Animais Selvagens da Agência Francesa para Segurança Alimentar, Ambiental e Ocupacional (ANSES) na cidade de Nancy, França; em razão do "kit" utilizado não apresentar licença de importação para o Brasil.

Foi utilizado o "kit" comercial Bio Pro Rabies ELISA Ab Kit ${ }^{\circledR}$ (O.K. servis Bio Pro®, Praga, Republica Tcheka) desenvolvido para o monitoramento de resposta vacinal em raposas (Anexo $B$ ).

Cada teste foi conduzido utilizando-se um soro controle positivo, um soro controle negativo e três soros controle internos (CS1,CS2,CS3) - todos fornecidos pelo "kit". A figura 20 representa o esquema da placa de ELISA. 
Figura 20- Esquema de divisão de placa de ELISA BioPro® para detecção de anticorpos contra o vírus da raiva. São Paulo, junho de 2012

\begin{tabular}{|c|c|c|c|c|c|c|c|c|c|c|c|c|}
\hline & 1 & 2 & 3 & 4 & 5 & 6 & 7 & 8 & 9 & 10 & 11 & 12 \\
\hline A & C- & A2 & $\mathrm{A} 10$ & A18 & A26 & A34 & A42 & A51 & A59 & A67 & A75 & A83 \\
\hline B & C- & A3 & A11 & A19 & A27 & A35 & A43 & A52 & A60 & A68 & A76 & A84 \\
\hline C & C+ & A4 & A12 & A20 & A28 & A36 & A44 & A53 & A61 & A69 & A77 & A85 \\
\hline D & $\mathrm{C}+$ & A5 & A13 & A21 & A29 & A37 & A45 & A54 & A62 & A70 & A78 & A86 \\
\hline $\mathrm{E}$ & CS1 & A6 & A14 & A22 & A30 & A38 & A46 & A55 & A63 & A71 & A79 & A87 \\
\hline$F$ & CS2 & A7 & A15 & A23 & A31 & A39 & A48 & A56 & A64 & A72 & A80 & A88 \\
\hline G & CS3 & A8 & A16 & A24 & A32 & A40 & A49 & A57 & A65 & A73 & A81 & A89 \\
\hline $\mathrm{H}$ & A1 & A9 & A17 & A25 & A33 & A41 & A50 & A58 & A66 & A74 & A82 & A90 \\
\hline \multicolumn{13}{|c|}{$\begin{array}{l}\text { C- - Controle negativo } \\
\text { C+ - Controle positivo } \\
\text { CS1, CS2, CS3 - Soros controle do "Kit" } \\
\text { A1 a A90 - Amostras a serem testadas } \\
\text { Fonte: Araujo (2012) }\end{array}$} \\
\hline
\end{tabular}

Os soros controle e os soros a serem testados $(A)$ foram homogeneizados em vórtex e diluídos na razão $1: 2,50 \mu \mathrm{L}$ de soro em $50 \mu \mathrm{L}$ de diluente. Após a diluição as placas foram incubadas por 24 horas ("overnight") a 2-8 ${ }^{\circ} \mathrm{C}$ com leve movimentação em um "orbital shaker".

No segundo dia da prova as placas foram lavadas por 06 vezes em solução de lavagem fornecida pelo "kit". Foram adicionados $100 \mu \mathrm{L}$ de anticorpo anti-raiva "Biotinylated ant-rabies antibody" e as amostras foram incubadas a $37^{\circ} \mathrm{C}$ por 30 minutos em "orbital shaker". As placas foram lavadas 04 vezes e adicionados $100 \mu \mathrm{L}$ de peroxidase de streptavidina - "Streptavidin Peroxidase Conjugate. Após nova incubação a $37^{\circ} \mathrm{C}$ por meia hora em "orbital shaker" as placas foram lavadas 04 vezes e adicionados $100 \mu \mathrm{L}$ de substrato TMB. As placas foram então incubadas a $25{ }^{\circ} \mathrm{C}$ por 18 minutos em "orbital shaker" e adicionados $50 \mu \mathrm{L}$ de "stop solution".

A leitura das placas foi realizada em leitor de ELISA em comprimento de onda de 450nm. Para que o teste fosse validado a média da Densidade Óptica (OD) dos controles negativos precisou apresentar valor maior do que 1.00 (OD > 1.0) e a diferença entre as médias dos controles negativos e positivos $\geq 0.8$ ((OD C-) - (OD $\mathrm{C}+) \geq 0.8)$. 
A porcentagem de bloqueio foi calculada utilizando-se a fórmula:

$$
\mathrm{PB} \%=\frac{\mathrm{OD}(\mathrm{C}-)-\mathrm{OD}(\text { amostra })}{\mathrm{OD}(\mathrm{C}-)-\mathrm{OC}(\mathrm{C}+)} \times 100
$$

Para validação do teste, os controle internos (CS1,CS2 e CS3) do kit foram também considerados, a deveria apresentar valores de PB do CS1 entre $45 \%$ e $70 \%$, a PB do CS2 entre $25 \%$ e $45 \%$ e a PB do CS3 menor do que $30 \%$.

Os soros apresentando PB menor que $40 \%$ foram considerados negativos, os soros com PB maior ou igual $40 \%$ considerados positivos e os soros com PB maior ou igual $70 \%$ considerados positivos com título igual ou maior do que $0.5 \mathrm{UI} / \mathrm{mL}$, baseado em comparações prévias com a prova de FAVN.

\subsection{Prova de Imunofluorescência Direta (IFD)}

A IFD foi realizada de acordo com a técnica recomendada pela WHO (DEAN; ALBESET; ATANASIU, 1996), empregando-se conjugado anti-rábico antinucleocapsídeo (policlonal) comercial (Bio-rad®).

Inicialmente foram realizadas impressões (decalques) do tecido nervoso central dos animais a serem testados em lâminas de vidro devidamente identificadas, a lâminas foram então fixadas em acetona PA à $-20{ }^{\circ} \mathrm{C}$ por 24 horas. Depois de fixadas, a lâminas foram secas em temperatura ambiente, acrescentou-se $30 \mu \mathrm{L}$ do conjugado e foi realizada incubação em câmara úmida a $37^{\circ} \mathrm{C}$ por 30 minutos. As lâminas foram lavadas em PBS $(\mathrm{pH} 7,2)$ por 10 minutos e foi realizada uma segunda lavagem com água destilada. As lâminas foram secas em temperatura ambiente e realizada a montagem das lâminas; as impressões são cobertas com glicerina tamponada $(\mathrm{pH} 8,3)$ e lamínula.

As lâminas foram observadas em microscópio de fluorescência aumento (40x), comparadas com controles, sendo o controle positivo realizado com cérebros de camundongos inoculados intra-cerebralmente com o vírus da raiva e o negativo com cérebros de camundongos sadios. 


\subsection{Inoculação Intracerebral em Camundongos (IC)}

A IC foi realizada de acordo com a técnica recomendada pela WHO (Koprowisk, 1996) utilizando-se camundongos albinos suíços. Os fragmentos de sistema nervoso central foram preparados triturando-se aproximadamente $0,5 \mathrm{~g}$ de tecido nervoso diluído em $20 \%$ de solução salina tamponada $(\mathrm{pH} 7,4)$ acrescida de $300 \mathrm{mg} / 100 \mathrm{ml}$ de antibiótico e $2 \%$ de soro normal inativado de eqüino (inativação por 30 minutos a $56{ }^{\circ} \mathrm{C}$ ). Foi realizada a centrifugação a 3000 rpm por 10 minutos a $4{ }^{\circ} \mathrm{C}$, sendo a suspensão mantida em refrigeração até o momento da utilização ou a - 70 ${ }^{\circ} \mathrm{C}$ até o momento de uso. Os camundongos (6-8 por amostra cerebral) foram inoculados intracerebralmente com $0,03 \mathrm{~mL}$ do sobrenadante da suspensão. Os camundongos foram observados diariamente para a verificação do aparecimento dos sintomas típicos da doença (pelos arrepiados, paralisia dos membros posteriores e óbito) durante 30 dias. Os animais que apresentaram sintomatologia ou morreram no período foram submetidos ao teste de Imunoflorescência Direta para confirmação do diagnóstico.

As provas de IFD e IC foram realizadas no Laboratório de Encefalites Virais do Instituto Biológico devido à necessidade de um biotério para manutenção e observação dos camundongos inoculados.

\subsection{Reação em Cadeia pela Polimerase precedida de transcrição (RT-PCR)}

Uma grande parte das amostras cerebrais utilizadas foi proveniente de animais encontrados mortos nos locais de captura ou nas estradas da região em estado de decomposição. Por este motivo, a RT-PCR foi utilizada em paralelo as técnicas de IFD e IC para a detecção do vírus da raiva.

A RT-PCR foi realizada de acordo com o protocolo desenvolvido pelo Núcleo de Pesquisas em Raiva para o projeto "Estudo genético da variante do vírus da raiva mantida por populações do morcego hematófago Desmodus rotundus por meio do seqüenciamento completo do genoma viral" (CAMPOS, 2011). Os oligonucleotídeos iniciadores ("primers") utilizados foram o Seq Nucleopr F750 desenhado durante o projeto citado; e o primer P304 descrito por Smith et al. em 1995. Os primers são 
direcionados para o gene responsável pela decodificação da nucleoproteína e amplificam um sequência de 765 pares de base.

Em decorrência do estado avançado de decomposição de algumas amostras, utilizou-se para todas um par de "primers" desenhados pelo Laboratório de Evolução Molecular e Bioinformática da Universidade de São Paulo para amplificação de uma região de aproximadamente 500pb (variável de acordo com a espécie animal) da região $16 S$ do RNA ribossomal de mamíferos, com o objetivo de verificação da viabilidade do RNA extraído.

Tabela 01- Nome, posição no N-gene, polaridade e sequência dos "primers" utilizados para detecção do RNA do vírus da raiva em mamíferos silvestres provenientes de área de Mata Atlântica nativa no litoral Norte do Estado de São Paulo, Brasil. Junho de 2012

\begin{tabular}{cccc}
\hline & Posição no Gene & Polaridade & Sequência \\
\hline SEQ_NuleoPr_F.750 & $749-766$ & Positiva & GGCACAGTWGTCACTGCT \\
\hline P304 & $1533-1514$ & Negativa & TTGACGAAGTCTTGTTCAT \\
\hline 16S - F & 16S RNA ribossomal & Positiva & CGCCTGTTTATCAAAAACAT \\
\hline 16S - R & 16S RNA ribossomal & Negativa & CCGGTCTGAACTCAGATCACGT \\
\hline
\end{tabular}

Fonte: Araujo (2012)

A extração foi realizada por meio do método TRIzol® (Invitrogen®, Carslbad, Ca, USA). As amostras cerebrais foram maceradas com $1000 \mu \mathrm{L}$ de água DEPC (Invitrogen ${ }^{\circledR}$ ) autoclavada no momento da extração. Foram então transferidos 500 $\mu \mathrm{L}$ do macerado para um microtubo e adicionados $500 \mu \mathrm{L}$ de TRIzol $\circledast$, seguido de homogeneização e incubação por 5 minutos em temperatura ambiente. Foram adicionados $200 \mu \mathrm{L}$ de clorofórmio (Merck), seguido de homogeneização em vórtex, incubação por 10 minutos em gelo e centrifugação por 15 minutos a $12000 \mathrm{~g}, 4^{\circ} \mathrm{C}$. O sobrenadante foi transferido para outro microtubo (aproximadamente $600 \mu \mathrm{L}$ ) e foram adicionados $500 \mu \mathrm{L}$ de propanol (Merck), seguido de homogeneização em vórtex, incubação por 10 minutos em gelo e centrifugação por 15 minutos a $12000 \mathrm{~g}$, $4^{\circ} \mathrm{C}$. Após a centrifugação o sobrenadante foi descartado e adicionou-se 100uL de etanol (Merck) 75\% ao "pellet" restante, seguido de homogeneização em vórtex e centrifugação à $7000 \mathrm{~g}$ por 7 minutos, $4{ }^{\circ} \mathrm{C}$. O sobranadante foi novamente descartado e o "pellet" seco em temperatura ambiente e ressuspendido em $30 \mu \mathrm{L}$ de 
água DEPEC autoclavada e $01 \mu \mathrm{L}(10 \mathrm{U})$ de Inibidor de Ribonuclease - RNAse Inhibitor (Invitrogen®).

A obtenção do DNA complementar (cDNA) foi realizada com 5,0 $\mu \mathrm{L}$ do RNA extraído adicionados à um "mix" contendo $200 \mathrm{U}$ de Transcriptase Reversa (RT) (MMLV - Moloney-murine leukemia virus/Super Script ${ }^{\mathrm{TM}}$-Invitrogen ${ }^{\circledR}$ ) diluídas em 8,0 $\mu \mathrm{L}$ de tampão da enzima - 5X "first strand buffer" $(50 \mathrm{mM}$ de tris- $\mathrm{HCl}(\mathrm{pH}-$ 8,3), $75 \mathrm{mM}$ de $\mathrm{KCl}, 3 \mathrm{mM} \mathrm{MgCl}$ ), $4 \mathrm{mM}$ de DTT, 1,2 mM de cada dNTP (dATP, dGTP, dTTP, dCTP/Invitrogen ${ }^{\circledR}$ ), 50 pmols de "primer" randômico , $10 \mathrm{U}$ de Inibidor de Ribonuclease (RNAse Inhibitor - Invitrogen ${ }^{\circledR}$ ), e $\mathrm{H}_{2} \mathrm{O} \mathrm{DEPC}{ }^{\circledR}$ (Invitrogen ${ }^{\circledR}$ ), em um volume final de $42 \mu \mathrm{L}$ A transcrição foi realizada em termobloco aquecido a $42{ }^{\circ} \mathrm{C}$ por 60 minutos.

A amplificação foi realizada utilizando-se 2,0 $\mu \mathrm{L}$ do cDNA extraído adicionado a um "mix" contendo tampão de reação $10 \mathrm{mM}$ tris- $\mathrm{HCl}, 50 \mathrm{mM}$ de $\mathrm{KCl}$ (PCR buffer 10X-Invitrogen ${ }^{\circledR}$ ), 2,5mM $\mathrm{MgCl} 2,0,25 \mathrm{mM}$ de cada dNTP, 25 pmoles de cada "primer" (SeqN e P304), 1,5U de Taq DNA polimerase (Invitrogen®) e H2O DEPC $®$ (Invitrogen $^{\circledR}$ ) para completar um volume final de $50 \mu \mathrm{L}$.

Para amplificação da região $16 \mathrm{~S}$ utilizou-se 8,0 $\mu \mathrm{L}$ do cDNA extraído adicionados a um "mix" contendo tampão de reação $10 \mathrm{mM}$ tris- $\mathrm{HCl}, 50 \mathrm{mM}$ de $\mathrm{KCl}$ (PCR buffer 10X-Invitrogen ${ }^{\circledR}$ ), 2,5mM de MgCl2, $05 \mathrm{mM}$ de cada dNTP, 25poml de cada "primer" (16S+ e 16S-), 1,5U de Taq DNA polimerase (Invitrogen®) e H2O DEPC $®\left(\right.$ Invitrogen $\left.{ }^{\circledR}\right)$ para completar um volume final de $50 \mu \mathrm{L}$.

As duas etapas de amplificação foram realizadas em termociclador Genamp® PCR System 9700, Applied Biosystens com pré-aquecimento a $95{ }^{\circ} \mathrm{C}$ por cinco minutos para denaturação seguida de 35 ciclos com 45 segundos a $94{ }^{\circ} \mathrm{C}, 45$ segundos a $55^{\circ} \mathrm{C}$ e 90 segundos a $72{ }^{\circ} \mathrm{C}$ e uma etapa de extensão final a $72{ }^{\circ} \mathrm{C}$ por 5 minutos.

Os produtos amplificados foram analisados por eletroforese em gel de agarose (Invitrogen ${ }^{\circledR}$ ) a 1,5\% em tampão TBE 1x (89 mM - tris $\mathrm{HCl} ; 89 \mathrm{mM} \mathrm{H}_{3} \mathrm{BO}_{3}$; $2 \mathrm{mM} \mathrm{Na}_{2}$ EDTA, pH 8,3 - Invitrogen ${ }^{\circledR}$ ) e 0,5 $\mu \mathrm{g} / \mathrm{mL}$ de brometo de etídio (Edt $\mathrm{Br}$ Sigma). Uma mistura de $10 \mu \mathrm{L}$ do produto amplificado de cada amostra e 2,0 $\mu \mathrm{L}$ de azul de bromofenol (loading buffer) foi aplicada no gel de agarose. O gel foi então submetido à eletroforese, em cuba horizontal, em tampão TBE (Invitrogen ${ }^{\circledR}$ ) durante 45 minutos a 100 volts. A visualização do gel foi realizada sobre transluminador de luz ultravioleta (UV) High Performance UV Transiluminator, UVP® sendo os 
resultados comparados aos controles positivos, negativos e aos marcadores de peso molecular $\left(1 \mathrm{~Kb}, \quad\right.$ Invitrogen $\left.{ }^{\circledR}\right)$, sendo a seguir fotodocumentados em fotodocumentador Multi-Doc - It Digital Imaging System, UVP®.

\subsection{Análise Estatística}

A análise estatística foi realizada determinando-se a relação entre as diferentes variáveis (local de captura, sexo e idade) por meio do teste de Quiquadrado $\left(\mathrm{X}^{2}\right)$ e Teste Exato de Fisher. $\mathrm{O}$ valor crítico para $\mathrm{X}^{2}$ adotado foi 3,84; e de p para o teste Exato de Fisher de 0,05 (FORTHOFER; LEE; HERNANDEZ, 2007).

A concordância entre os testes foi determinada por meio do Coeficiente Kappa (K). Os valores acima 0,80 são interpretados como uma concordância muito boa; os valores entre 0,6 e 0,8 como uma concordância boa; entre 0,5 e 0,6 como aceitável; entre 0,4 e 0,5 como moderada e os valores abaixo de 0,40 como uma concordância ruim. Quanto mais próximo a 1 (um) perfeita é a concordância entre os testes, e os valores mais próximos de 0 (zero) indicam uma concordância aleatória (NOORDHUIZEN et al., 1997).

Foram também determinadas a sensibilidade e a especificidade diagnósticas segundo as fórmulas 02 e 03 definidas por Thrusfield (1986):

$$
\text { Sensibilidade }(S)=a /(a+c) \times 100
$$

$a=$ número de amostras detectadas como positivas que realmente eram positivas.

$c=$ número de amostras positivas que a técnica identificou como negativas.

$$
\text { Fórmula 03: Especificidade }(E)=d /(b+d) \times 100
$$

$\mathrm{b}=$ número de amostras negativas que a técnica identificou como positivas no grupo das amostras negativas.

d = número de amostras efetivamente negativas consideradas negativas pela técnica.

A prova de RFFIT foi considerada como padrão ouro. 


\section{RESULTADOS}

\subsection{Animais capturados}

No período de junho de 2009 a novembro de 2011, foram capturados 206 animais de 07 diferentes ordens animais compreendendo 15 espécies. Sendo a ordem animal Didelphimorphia (141 gambás e 01 cuíca) a predominantemente observada com 142 animais (68,9\%), seguida pelas ordens Primata (macaco-prego, 37 animais, 17,9\%), Carnivora (04 quatis, 03 jaguatiricas, 01 gato maracajá, 01 mão pelada e 01 cachorro do mato, em um total de 10 animais, 4,8\%), Cingulata (tatu, 08 animais, 3,8\%), Rodentia (03 cutias, 02 ratos silvestres, 01 rato do mato e 01 ratão do banhado - 07 animais, 3,4\%), Artiodactyla e Pilosa (tamanduá e caititu, 01 animal, 0,48\% cada), A figura 21 apresenta o gráfico com a distribuição das ordens. A tabela 02 apresenta a relação das espécies capturadas divididas de acordo com área de captura.

Figura 21- Distribuição, segundo a ordem animal, de mamíferos silvestres capturados em área de Mata Atlântica nativa no litoral Norte do Estado de São Paulo, Brasil. São Paulo, junho de 2012

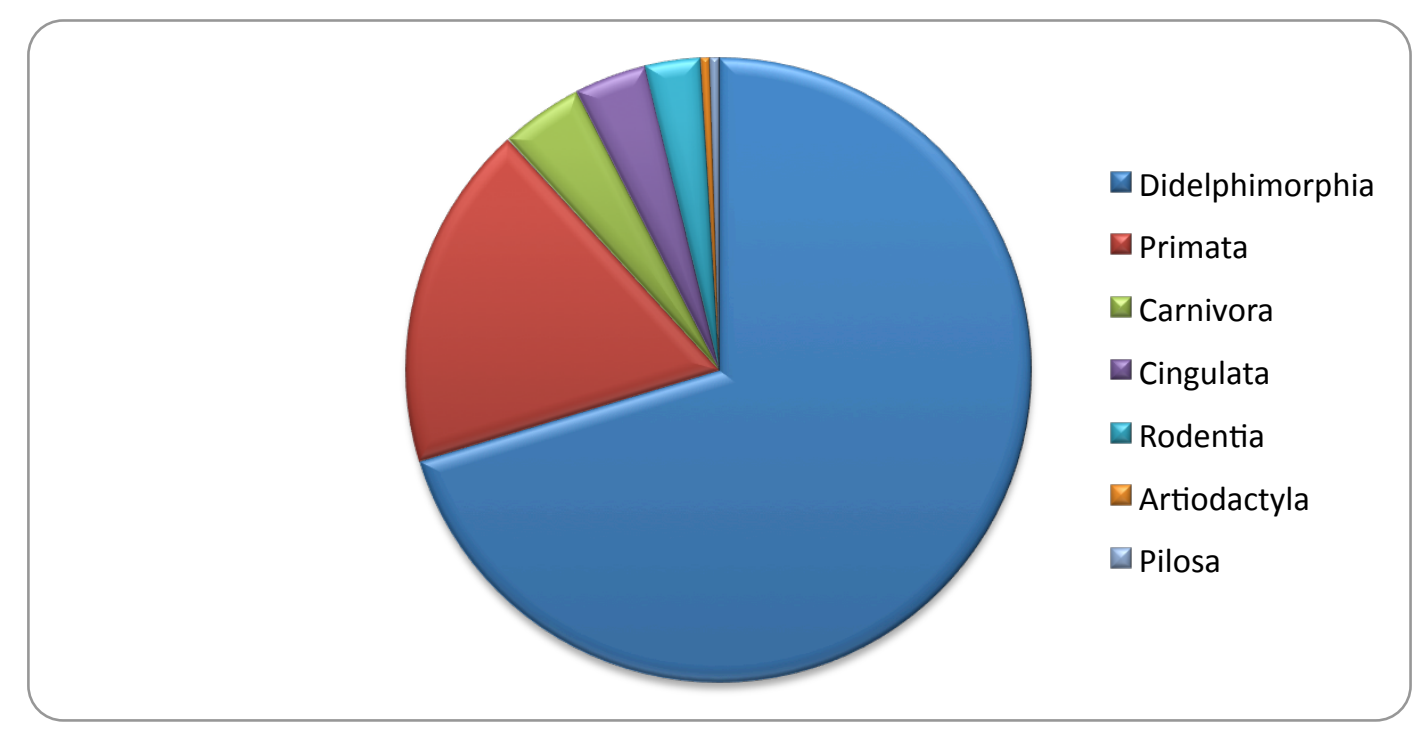

Fonte: Araujo (2012) 
Tabela 02 - Relação segundo a ordem animal e local de captura de mamíferos silvestres capturados em área de Mata Atlântica nativa no litoral Norte do Estado de São Paulo, Brasil. Junho de 2012

\begin{tabular}{ccccc}
\hline Animal & Espécie & Total & FA & RSL \\
\hline Gambás & Didelphis aurita & 141 & 90 & 51 \\
Macaco prego & Cebus apella & 37 & 26 & 11 \\
Tatu & Dasypus novemcinctus & 08 & 00 & 08 \\
Jaguatirica & Leopardus pardalis & 03 & 03 & 00 \\
Tamanduá & Tamandua tetradactyla & 01 & 00 & 01 \\
Quati & Nasua nasua & 04 & 02 & 02 \\
Rato silvestre & Oligoryzomys nigripes & 02 & 00 & 02 \\
Mão pelada & Procyon cancrivorous & 01 & 01 & 00 \\
Ratãodo banhado & Myocastor coypus & 01 & 00 & 01 \\
Cutia & Dasyprocta aguti & 03 & 03 & 00 \\
Cuíca & Metachirus opossum & 01 & 00 & 01 \\
Cachorro do mato & Cerdocyon thous & 01 & 00 & 01 \\
Rato do mato & Akodon cursor & 01 & 00 & 01 \\
Caititu & Tayassu tajacu & 01 & 01 & 00 \\
Gato Maracajá & Leopardus wiedii & 01 & 01 & 00 \\
\hline Total & & 206 & 127 & 79
\end{tabular}

FA: Fazenda Acaraú (área de soltura)

RSL: Riviera de São Lourenço (local de construção de condomínio residencial)

Fonte: Araujo (2012)

Do total de 206 animais capturados, $127(61,6 \%)$ foram provenientes da área de soltura da Fazenda Acaraú (FA), compreendendo 08 espécies: sendo 90 gambás $(70,8 \%), 26$ macacos-prego $(20,4 \%), 03$ jaguatiricas $(2,3 \%), 03$ cutias $(2,3 \%), 02$ quatis $(1,5 \%)$ e $01(0,78 \%)$ animal de cada das seguintes espécies: mão pelada, caititu e gato-maracajá. O figura 22 representa a divisão das espécies animais capturadas na área da Fazenda Acaraú. 
Figura 22- Distribuição segundo a espécie de mamíferos silvestres capturados em área de soltura de Mata Atlântica nativa no litoral Norte do Estado de São Paulo Brasil. São Paulo, junho de 2012

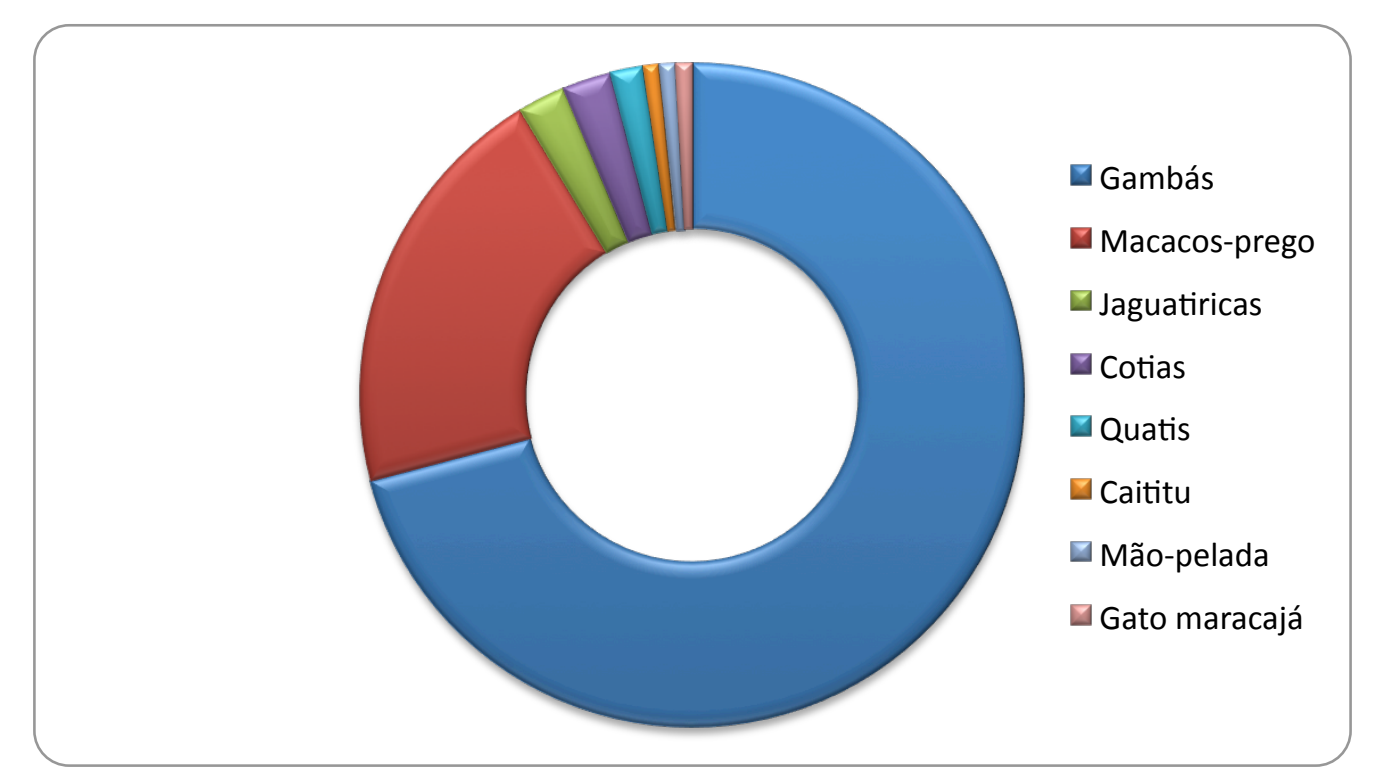

Fonte: Araujo (2012)

Do total de 206 animais capturados, $79(38,4 \%)$ animais foram provenientes da área de construção do condomínio (RSL - Riveira de São Lourenço), compreendendo 10 espécies: sendo 51 gambás (64,5\%), 11 macacos-prego $(13,9 \%), 08$ tatus $(10,1 \%), 02$ quatis $(2,5 \%), 02$ ratos silvestres $(2,5 \%), 01(1,26 \%)$ cuíca, tamanduá, rato do mato, ratão do banhado e cachorro do mato. A figura 23 representa a divisão das espécies animais na área. 
Figura 23- Distribuição segundo a espécie de mamíferos silvestres capturados no local de construção de condomínio residencial em área de Mata Atlântica nativa no litoral Norte do Estado de São Paulo Brasil. São Paulo, junho de 2012

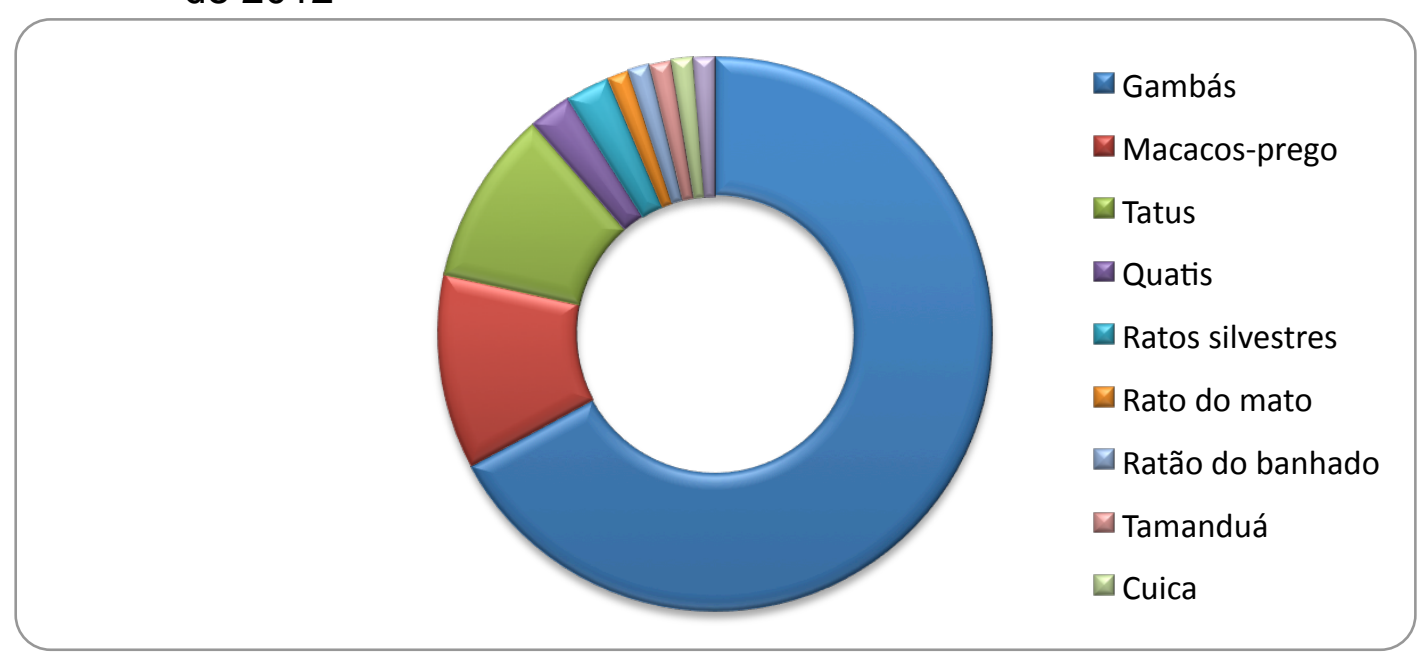

Fonte: Araujo (2012)

Todas as atividades na área da Riviera de São Lourenço, incluindo as capturas, foram interrompidas em maio de 2011. Desde o início da realização das capturas para este projeto até a data de suspensão das atividades foi obtido um total de 159 amostras, sendo 82 (51,5\%) provenientes da Fazenda Acaraú e 77 (48,5\%) da Riviera de São Lourenço. A figura 24 representa a quantidade de animais nos dois períodos.

Figura 24- Total de mamíferos silvestres capturados nas áreas FA e RSL em área de Mata Atlântica nativa no litoral Norte do Estado de São Paulo, Brasil, nos períodos de 06/2009 a 05/2011 e 06/2009 a 10/2011. São Paulo, junho de 2012.

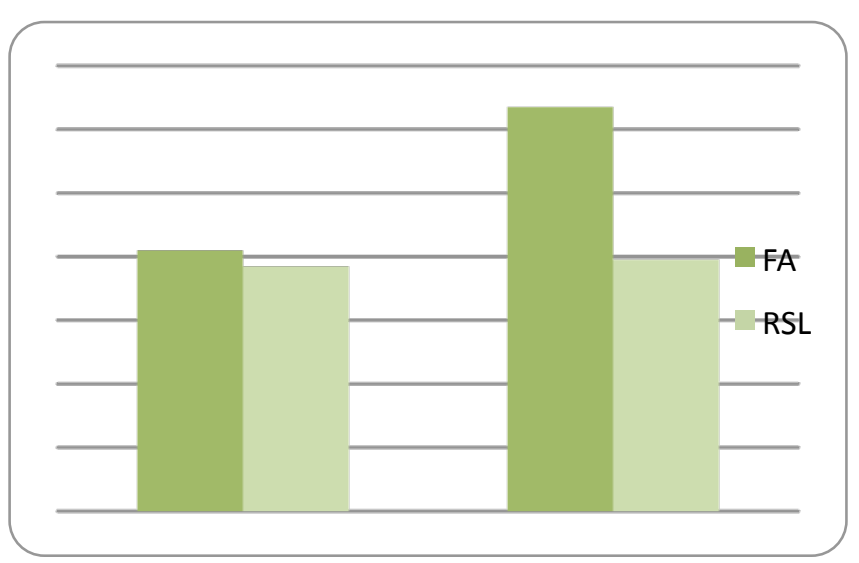

Fonte: Araujo (2012) 
Foram capturados 119 (57,7\%) machos, 77 (37,3\%) fêmeas e 10 (4,8\%) animais com gênero indeterminado dentre o total de 206 animais provenientes das duas áreas.

Foram capturados 74 (58,3\%) machos, 50 (39,4\%) fêmeas e 03 (2,0\%) com gênero indeterminado dentre os 127 animais provenientes da Fazenda Acaraú.

Foram capturados 45 (57\%) machos, 27 fêmeas (34,1\%) e $07(8,9 \%)$ animais com gênero indeterminado dentre o total de 79 animais provenientes da Riviera de São Lourenço.

A figura 25 representa a distribuição dos animais de acordo com o gênero e o local de captura.

Figura 25- Distribuição de acordo com o gênero de mamíferos silvestres capturados nas áreas RSL e FA em área de Mata Atlântica nativa no litoral Norte do Estado de São Paulo, Brasil. São Paulo, junho de 2012

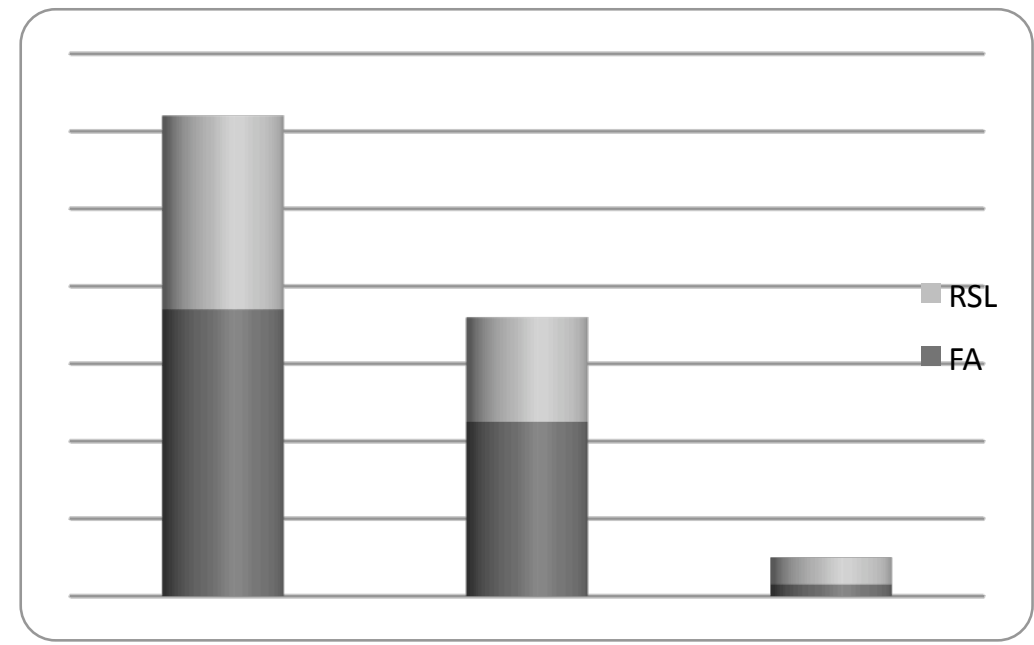

RSL - Riviera de São Lourenço (área de construção de condomínio residencial) FA - Fazenda Acaraú (área de soltura) Fonte: Araujo (2012)

Foram capturados $144(70,0 \%)$ adultos, 45 jovens $(21,8 \%)$ e $17(8,2 \%)$ animais com idade indeterminada dentre o total de 206 animais provenientes das duas áreas.

Foram capturados 99 (78\%) adultos, 19 (15\%) jovens e 09 (7\%) animais com idade indeterminada dentre os 127 animais provenientes área da Fazenda Acaraú.

Foram capturados $45(56,9 \%)$ adultos, 25 (31,6\%) jovens e 08 (10\%) animais com idade indeterminada dentre os 79 animais provenientes da área da Riviera de São Lourenço. 
A figura 26 representa a distribuição dos animais de acordo com a idade e local de captura.

Figura 26- Distribuição, de acordo com a idade de mamíferos silvestres capturados nas áreas RSL e FA em área de Mata Atlântica nativa no litoral Norte do Estado de São Paulo, Brasil. São Paulo, junho de 2012

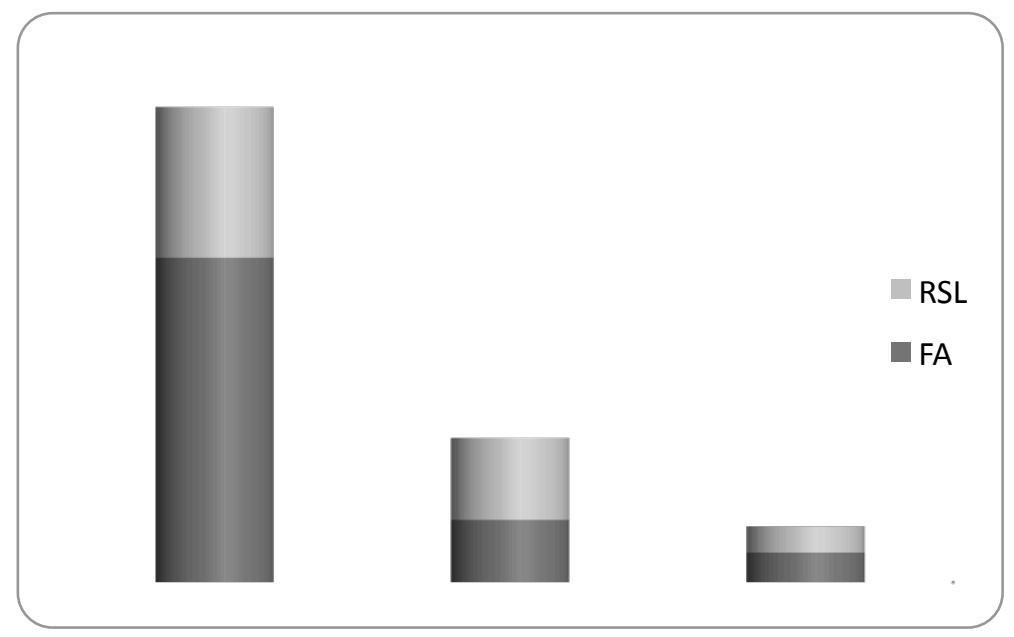

RSL - Riviera de São Lourenço (área de construção de condomínio residencial) FA - Fazenda Acaraú (área de soltura)

Fonte: Araujo (2012)

\subsection{Microteste simplificado de inibição da fluorescência - "Simplified fluorescent inhibition microtest for the titration of rabies neutralizing antibodies" - SFIMT}

Todas as amostras de soro obtidas e em condições de análise (provenientes dos 206 animais capturados) foram submetidas ao SFIMT. Foram considerados positivos os animais com detecção de anticorpos neutralizantes, isto é, os que apresentaram títulos $\geq 0,16 \mathrm{UI} / \mathrm{mL}$.

As amostras analisadas foram provenientes de 15 diferentes espécies de mamíferos silvestres; 70 (34,0\%) apresentaram títulos $\geq 0,16 \mathrm{Ul} / \mathrm{mL}$ (Unidades Internacionais por Microlitro), dentre as quais $20(9,7 \%)$ apresentaram títulos $\geq 0,5 \mathrm{Ul} / \mathrm{mL}$ (considerados como protetores para o vírus da raiva em humanos) (Tabela 03). Os títulos de anticorpos observados variaram entre $<0,16 \mathrm{Ul} / \mathrm{mL}$ e $\geq 1,00 \mathrm{UI} / \mathrm{mL}$. 
Tabela 03- Resultados do SFIMT em mamíferos silvestres provenientes de área de Mata Atlântica nativa no litoral Norte do Estado de São Paulo, Brasil. Junho de 2012

\begin{tabular}{lcc}
\hline & $\begin{array}{c}\text { Títulos } \\
\geq 0,16 \mathrm{UI} / \mathrm{mL}\end{array}$ & $\begin{array}{c}\text { Títulos } \\
\mathbf{0 0 , 5 0 U 1 / m L}\end{array}$ \\
\hline Número de animais & $70 / 206$ & $20 / 206$ \\
Porcentagem & $34,0 \%$ & $9,7 \%$ \\
\hline
\end{tabular}

SFIMT: Microteste simplificado de inibição da fluorescência $\geq 0,16 \mathrm{UI} / \mathrm{mL}$ : Titulo considerado positivo (detecção de anticorpos neutralizantes) $\geq 0,50 \mathrm{Ul} / \mathrm{mL}$ : Títulos considerados como protetores após vacinação Fonte: Araujo (2012)

Os gambás (Didelphis aurita) foram a espécie predominante também na detecção de anticorpos neutralizantes por meio do SFIMT: 51 animais $(37,1 \%)$ apresentaram títulos $\geq 0.16 \mathrm{UI} / \mathrm{mL}$ dentre o total 140 animais capturados, e 14 animais $(10 \%)$ apresentaram títulos $\geq 0,5 \mathrm{Ul} / \mathrm{mL}$.

Os macacos-prego (Cebus apella nigritus) foram a segunda espécie predominante: $08(21,6 \%)$ animais dentre o total de 37 animais capturados, sendo $04(10,8 \%)$ apresentando títulos $\geq 0,50 U \mathrm{U} / \mathrm{ML}$.

Um total de $03(37,5 \%)$ tatus (Dasypus novemcinctus) dentre os 08 capturados apresentaram títulos $\geq 0,16 \mathrm{UI} / \mathrm{mL}$, embora nenhum com título $\geq 0,50 \mathrm{UI} / \mathrm{mL}$.

Dentre os 04 quatis (Nasua nasua) capturados, 02 apresentaram títulos $\geq 0,16 \mathrm{UI} / \mathrm{mL}$ sendo $01 \geq 0,50 \mathrm{Ul} / \mathrm{mL}$. Dentre as 03 cutias (Dasyprocta aguti) capturadas, 01 apresentou título de 0,5UI/mL.

Dentre as 03 jaguatiricas (Leopardus pardalis) capturadas, 01 apresentou titulo $=0,16 \mathrm{UI} / \mathrm{mL}$ e em nenhuma foram observados títulos $\geq 0.50 \mathrm{UI} / \mathrm{mL} ; 01$ tamanduá (Tamandua tetradactyla) apresentou título $=0,16 \mathrm{Ul} / \mathrm{mL} ; 01$ cachorro do mato (Cerdocyon thous) apresentou título =0,25UI/mL; 01 mão-pelada (Procyon cancrivorous) apresentou título $=0,33 \mathrm{UI} / \mathrm{mL}$ e 01 caititu (Tayassu tajacu) apresentou título =0,33UI $/ \mathrm{mL}$.

As espécies rato silvestre (Oligoryzomys nigripes), rato do mato (Akodon cursor), ratão do banhado (Myocastor coypus) e gato maracajá (Leopardus wiedii) não apresentaram títulos de anticorpos neutralizantes detectáveis. 
A Tabela 04 relaciona o número de amostras por espécies e os respectivos títulos observados.

Tabela 04-Resultados do SFIMT, segundo a espécie animal, em mamíferos silvestres provenientes de área de Mata Atlântica nativa no litoral norte do Estado São Paulo, Brasil. Junho de 2012

\begin{tabular}{ccccc}
\hline Animal & Espécie & Total & $\geq \mathbf{0 , 1 6 U I / m L ~ ( \% ) ~}$ & $\geq \mathbf{0 , 5 0 U} / \mathbf{m L}(\mathbf{\%})$ \\
\hline Gambás & Didelphis aurita & 140 & $51(36,1 \%)$ & $14(10 \%)$ \\
Macaco prego & Cebus apella & 37 & $08(21,6 \%)$ & $04(10,8 \%)$ \\
Tatu & Dasypus novemcinctus & 09 & $03(33,3 \%)$ & $00(00 \%)$ \\
Jaguatirica & Leopardus pardalis & 03 & $01(33,3 \%)$ & $00(00 \%)$ \\
Tamanduá & Tamandua tetradactyla & 01 & $01(100 \%)$ & $00(00 \%)$ \\
Quati & Nasua nasua & 04 & $02(50.0 \%)$ & $01(25,0 \%)$ \\
Rato silvestre & Oligoryzomys nigripes & 02 & $00(00 \%)$ & $00(00 \%)$ \\
Mão pelada & Procyon cancrivorous & 01 & $01(100 \%)$ & $00(00 \%)$ \\
Ratãodo banhado & Myocastor coypus & 01 & $00(00 \%)$ & $00(00 \%)$ \\
Cutia & Dasyprocta aguti & 03 & $01(33,3 \%)$ & $01(33,3 \%)$ \\
Cuíca & Metachirus opossum & 01 & $00(00 \%)$ & $00(00 \%)$ \\
Cachorro do mato & Cerdocyon thous & 01 & $01(100 \%)$ & $00(00 \%)$ \\
Rato do mato & Akodon cursor & 01 & $00(00 \%)$ & $00(00 \%)$ \\
Caititu & Tayassu tajacu & 01 & $01(100 \%)$ & $00(00 \%)$ \\
Gato Maracajá & Leopardus wiedii & 01 & $00(00 \%)$ & $00(00 \%)$ \\
\hline Total & & 206 & 70 & 20 \\
\hline
\end{tabular}

SFIMT: Microteste simplificado de inibição da fluorescência $\geq 0,16 \mathrm{UI} / \mathrm{mL}$ : Titulo considerado positivo (detecção de anticorpos neutralizantes) $\geq 0,50 \mathrm{Ul} / \mathrm{mL}$ : Títulos considerados como protetores após vacinação Fonte: Araujo (2012)

Dentre as 127 amostras provenientes da Fazenda Acaraú (FA), 46 (36\%) apresentaram títulos $\geq 0,16 \mathrm{UI} / \mathrm{mL}$, dentre as quais $15(11,8 \%$ do total de animais provenientes da área FA) apresentaram títulos $\geq 0,5 \mathrm{Ul} / \mathrm{mL}$.

Dentre as amostras dos 79 animais provenientes de coletas na área de construção do condomínio (RSL) 24 (30\%) apresentaram títulos $\geq 0,16 U \mathrm{Ul} / \mathrm{mL}$ e 05 $(6,3 \%$ do total de animais provenientes da área RSL) títulos $\geq 0,5 \mathrm{Ul} / \mathrm{mL}$. (Tabela 05$)$.

$\mathrm{O}$ valor de $\mathrm{X}^{2}$ foi de 0,742 indicando que a diferença entre os resultados observados nas áreas FA e RSL não foi estatisticamente significante. 
Tabela 05-Resultados do SFIMT*, segundo a área de captura, em mamíferos silvestres provenientes de área de Mata Atlântica nativa no litoral Norte do Estado de São Paulo, Brasil. Junho de 2012

\begin{tabular}{c|ccc}
\hline & Positivos & Negativos & Total \\
\hline RSL & 24 & 55 & 79 \\
FA & 46 & 81 & 127 \\
\hline Total & 70 & 136 & 206
\end{tabular}

Estatística: $\mathrm{X}^{2}=0,741(\mathrm{gl}=1)$ indicando que a diferença entre os resultados observados nas áreas $\mathrm{F} A$ e RSL não foi estatisticamente significante.

SFIMT: Microteste simplificado de inibição da fluorescência

*: Número de animais com presença de anticorpos neutralizantes (títulos $\geq 0,16 \mathrm{UI} / \mathrm{mL}$ )

Fonte: Araujo (2012)

41 machos $(34,4 \%$ do total de 119 amostras) apresentaram títulos $\geq 0,16 \mathrm{UI} / \mathrm{mL}$ e $11(9,2 \%)$ apresentaram títulos $\geq 0,50 U \mathrm{I} / \mathrm{mL}$. Em relação as fêmeas, $25(32,4 \%)$ do total de 77 amostras de soro submetidas ao SFIMT apresentaram títulos $\geq 0,16 \mathrm{UI} / \mathrm{mL}$ sendo $08(10,3 \%)$ apresentando títulos $\geq 0,50 U \mathrm{I} / \mathrm{mL}$. Dos 10 animais com gênero indeterminado, 04 (40\%) apresentaram títulos $\geq 0,16 U \mathrm{I} / \mathrm{mL}$ e 01 (10\%) apresentou título $\geq 0,50 U \mathrm{Ul} / \mathrm{mL}$ (Tabela 06).

$\mathrm{O}$ valor de $\mathrm{X}^{2}$ foi de 0,083 indicando que a diferença entre os resultados observados em machos e fêmeas não foi estatisticamente significante.

Tabela 06- Resultados do SFIMT*, segundo o gênero, em mamíferos silvestres provenientes de área de Mata Atlântica nativa no litoral Norte do Estado de São Paulo, Brasil. Junho de 2012

\begin{tabular}{c|ccc}
\hline & Positivos & Negativos & Total \\
\hline Machos & 41 & 78 & 119 \\
Fêmeas & 25 & 52 & 77 \\
Indefinido & 04 & 06 & 10 \\
\hline Total & 70 & 136 & 206 \\
\hline
\end{tabular}

Estatística: $\mathrm{X}^{2}=0,083(\mathrm{gl}=1)$ indicando que a diferença entre os resultados observados em machos e fêmeas não foi estatisticamente significante.

SFIMT: Microteste simplificado de inibição da fluorescência

*: Número de animais com presença de anticorpos neutralizantes (títulos $\geq 0,16 \mathrm{Ul} / \mathrm{mL}$ )

Fonte: Araujo (2012) 
Considerando-se as 144 amostras de animais adultos submetidas ao SFIMT, $50(34,7 \%)$ apresentaram títulos $\geq 0,16 \mathrm{Ul} / \mathrm{mL}$ sendo $16(11 \%)$ apresentando títulos $\geq$ $0,50 \mathrm{Ul} / \mathrm{mL}$. Dentre as 45 amostras provenientes de animais jovens, $10(22,2 \%)$ apresentaram títulos $\geq 0,16 \mathrm{UI} / \mathrm{mL}$ sendo $02(4,4 \%)$ apresentando títulos $\geq 0,50 \mathrm{UI} / \mathrm{mL}$. Das 17 amostras de animais com idade indefinida, 10 (58,8\%) apresentaram títulos $\geq 0,16 \mathrm{UI} / \mathrm{mL}$ sendo $02(11,7 \%)$ apresentando títulos $\geq 0,50 \mathrm{UI} / \mathrm{mL}$ (Tabela 07 ).

$\mathrm{O}$ valor de $\mathrm{X}^{2}$ foi de 2,472 indicando que a diferença entre os resultados observados em adultos e jovens não foi estatisticamente significante.

Tabela 07-Resultados do SFIMT*, segundo a idade, em mamíferos silvestres provenientes de área de Mata Atlântica nativa no litoral Norte do Estado de São Paulo, Brasil. Junho de 2012

\begin{tabular}{c|ccc}
\hline & Positivos & Negativos & Total \\
\hline Adultos & 50 & 94 & 144 \\
Jovens & 10 & 35 & 45 \\
Indefinido & 10 & 7 & 17 \\
\hline Total & 70 & 136 & 206 \\
\hline
\end{tabular}

Estatística: $X^{2}=2,472(g l=1)$ indicando que a diferença entre os resultados observados em adultos e jovens não foi estatisticamente significante.

SFIMT: Microteste simplificado de inibição da fluorescência

*: Número de animais com presença de anticorpos neutralizantes (títulos $\geq 0,16 \mathrm{UI} / \mathrm{mL}$ )

Fonte: Araujo (2012)

\subsection{Teste Rápido de Inibição de Foco da Fluorescência- "Rapid Fluorescent Focus Inhibition Test"- RFFIT}

Devido a quantidade insuficiente de algumas amostras de soro, 139 amostras $(67,5 \%$ do total de amostras de soro obtidas) foram submetidas ao RFFIT. Dentre estas 139 amostras, 15 (10,8\%) foram reagentes (títulos $\geq 0,11 \mathrm{Ul} / \mathrm{mL}$ ); e apenas 01 amostra (proveniente de um gambá, adulto e do sexo feminino proveniente da área da Fazenda Acaraú - FA2447) apresentou título $\geq 0,5 \mathrm{UI} / \mathrm{mL}$.

Dentre o total de 109 amostras provenientes de gambás submetidas ao RFFIT, 12(11\%) foram reagentes.

Dentre o total de 15 amostras de macaco prego submetidas ao RFFIT, 01 $(6,6 \%)$ foi reagente

As duas amostras provenientes de quati foram regantes. 
Nas amostras provenientes das demais espécies ( 05 tatus, 02 jaguatiricas, 01 gato maracajá, 01 cuíca, 01 cutia, 01 caititu, 01 rato silvestre e 01 ratão do banhado) não foram observados AcNs.

A tabela 08 apresenta a relação completa dos animais com amostras reagentes (apresentando detecção de anticorpos neutralizantes), espécie, gênero, idade e os respectivos títulos observados.

Tabela 08- Resultados do RFFIT* (identificação, animal, espécie, gênero e idade) em mamíferos silvestres provenientes de área de Mata Atlântica nativa no litoral Norte do Estado de São Paulo, Brasil. Junho de 2012

\begin{tabular}{|c|c|c|c|c|c|}
\hline Número & Animal & Espécie & Gênero & Idade & Titulo RFFIT \\
\hline FA1863 & Gambá & Didelphis aurita & $M$ & A & $=0,12 U \mathrm{U} / \mathrm{mL}$ \\
\hline FA2078 & Gambá & Didelphis aurita & M & A & $=0,19 U \mathrm{U} / \mathrm{mL}$ \\
\hline RSL4232 & Quati & Nasua nasua & M & A & $=0,20 U \mathrm{U} / \mathrm{mL}$ \\
\hline FA2014 & Gambá & Didelphis aurita & M & A & $=0,20 U \mathrm{U} / \mathrm{mL}$ \\
\hline FA2267 & M. prego & Cebus apella & M & I & $=0,33 \mathrm{UI} / \mathrm{mL}$ \\
\hline FA2277 & Quati & Nasua nasua & $F$ & A & $=0,12 \mathrm{UI} / \mathrm{mL}$ \\
\hline FA4390 & Gambá & Didelphis aurita & M & $\mathrm{J}$ & $=0,12 \mathrm{UI} / \mathrm{mL}$ \\
\hline FA3584 & Gambá & Didelphis aurita & M & $\mathrm{J}$ & $=0,12 U \mathrm{U} / \mathrm{mL}$ \\
\hline RSL4564 & Gambá & Didelphis aurita & M & A & $=0,16 \mathrm{UI} / \mathrm{mL}$ \\
\hline FA2508 & Gambá & Didelphis aurita & $F$ & A & $=0,16 \mathrm{UI} / \mathrm{mL}$ \\
\hline FA2447 & Gambá & Didelphis aurita & $F$ & A & $=1,00 U \mathrm{U} / \mathrm{mL}$ \\
\hline FA2541 & Gambá & Didelphis aurita & M & A & $=0,11 \mathrm{UI} / \mathrm{mL}$ \\
\hline RSL4780 & Gambá & Didelphis aurita & $F$ & A & $=0,16 \mathrm{UI} / \mathrm{mL}$ \\
\hline FA2940 & Gambá & Didelphis aurita & M & A & $=0,14 U \mathrm{UI} / \mathrm{mL}$ \\
\hline RSL4838 & Gambá & Didelphis aurita & M & A & $=0,11 \mathrm{UI} / \mathrm{mL}$ \\
\hline
\end{tabular}

RFFIT: Teste rápido de inibição de foco de fluorescência

*: Número de animais com presença de anticorpos neutralizantes (títulos $\geq 0,11 \mathrm{UI} / \mathrm{mL}$ )

FA: Fazenda Acaraú (área de soltura)

RSL: Riviera de São Lourenço (área de construção de condomínio residencial)

Fonte: Araujo (2012) 
Dentre as 139 amostras de soro submetidas ao RFFIT, 88 (63,3\%) foram provenientes da área da Fazenda Acaraú, sendo 11 (12,5\% dos animais provenientes da área FA) reagentes e 51 (36,6\%) amostras foram provenientes da área da Riviera de São Lorenço, sendo 04 (7,8\% dos animais provenientes da área $\mathrm{RSL}$ ) reagentes (títulos $\geq 0,11 \mathrm{UI} / \mathrm{mL}$ ).

$\mathrm{O}$ valor de $\mathrm{X}^{2}$ foi de 0,727 , indicando que a diferença entre os resultados observados nas áreas FA e RSL não foi estatisticamente significante. A tabela 09 apresenta a divisão dos animais de acordo com a área em que foram capturados e o número de amostras reagentes.

Tabela 09-Resultados do RFFIT*, segundo o local de captura, em mamíferos silvestres provenientes de área de Mata Atlântica nativa no litoral Norte do Estado de São Paulo, Brasil. Junho de 2012

\begin{tabular}{c|ccc}
\hline & Positivos & Negativos & Total \\
\hline FA & 11 & 77 & 88 \\
RSL & 04 & 47 & 51 \\
\hline Total & 15 & 124 & 139
\end{tabular}

Estatística: $\mathrm{X}^{2}=0,727(\mathrm{gl}=1)$ indicando que a diferença entre os resultados observados nas áreas FA e RSL não foi estatisticamente significante.

RFFIT: Teste rápido de inibição de foco de fluorescência

*: Número de animais com presença de anticorpos neutralizantes (títulos $\geq 0,11 \mathrm{UI} / \mathrm{mL}$ )

FA: Fazenda Acaraú (área de soltura)

RSL: Riviera de São Lourenço (área de construção de condomínio residencial)

Fonte: Araujo (2012)

Dentre as 139 amostras submetidas ao RFFIT, 81 (58,2\%) foram provenientes de machos, sendo $11(13,5 \%$ dos machos) reagentes (títulos

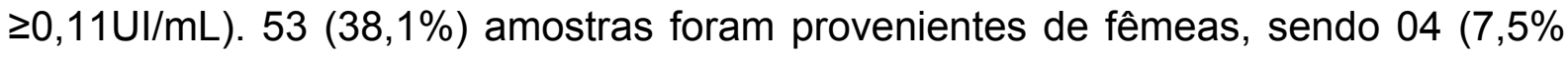
das fêmeas) reagentes (títulos $\geq 0,11 \mathrm{UI} / \mathrm{mL})$; 05 (3,6\%) amostras foram provenientes de animais com gênero indeterminado e em nenhuma foram observados AcNs.

$\mathrm{O}$ valor de $\mathrm{X}^{2}$ foi de 1,173 indicando que a diferença entre os resultados observados em machos e fêmeas não foi estatisticamente significante. A tabela 10 apresenta a divisão dos animais de acordo com o gênero e o número de amostras reagentes. 
Tabela 10-Resultados do RFFIT*, segundo o gênero, em mamíferos silvestres provenientes de área de Mata Atlântica nativa no litoral Norte do Estado de São Paulo, Brasil. Junho de 2012

\begin{tabular}{c|ccc}
\hline & Positivos & Negativos & Total \\
\hline Machos & 11 & 70 & 81 \\
Fêmeas & 04 & 49 & 53 \\
Indeterminado & 00 & 05 & 05 \\
\hline Total & 15 & 124 & 139
\end{tabular}

Estatística: $\mathrm{X}^{2}=1,173(\mathrm{gl}=1)$ indicando que a diferença entre os resultados observados em machos e fêmeas não foi estatisticamente significante.

RFFIT: Teste rápido de inibição de foco de fluorescência

*: Número de animais com presença de anticorpos neutralizantes (títulos $\geq 0,11 \mathrm{UI} / \mathrm{mL}$ )

Fonte: Araujo (2012)

Dentre as 139 amostras submetidas ao RFFIT, 102 (73,4\%) foram provenientes de animais adultos, sendo 12 (11,8\% dos adultos) positivas (títulos $\geq 0,11 \mathrm{Ul} / \mathrm{mL}) .28(20 \%)$ amostras foram provenientes animais jovens, sendo $02(7,1 \%$ dos jovens) reagentes (títulos $\geq 0,11 \mathrm{Ul} / \mathrm{mL}$ ); 09 (6,4\%) amostras foram provenientes de animais com idade indeterminada e uma ( $11 \%$ dos indeterminados) foi reagente.

$O$ valor de $p$ para o Teste Exato de Fischer foi de 0,23 $(>0,05)$ indicando que a diferença entre os resultados observados em adultos e jovens não foi estatisticamente significante (Tabela 11).

Tabela 11- Resultados do RFFIT*, segundo o gênero, em mamíferos silvestres provenientes de área de Mata Atlântica nativa no litoral Norte do Estado de São Paulo, Brasil. Junho de 2012

\begin{tabular}{c|ccc}
\hline & Positivos & Negativos & Total \\
\hline Adultos & 12 & 90 & 102 \\
Jovens & 02 & 26 & 28 \\
Indeterminado & 01 & 08 & 09 \\
\hline Total & 15 & 124 & 139
\end{tabular}

Estatística: $p=0,23$ para o Teste Exato de Fischer $(>0,05)$ indicando que a diferença entre os resultados observados em adultos e jovens não foi estatisticamente significante.

RFFIT: Teste rápido de inibição de foco de fluorescência

*: Número de animais com presença de anticorpos neutralizantes (títulos $\geq 0,11 \mathrm{UI} / \mathrm{mL}$ )

Fonte: Araujo (2012) 


\subsection{Comparação entre o Microteste simplificado de inibição da fluorescência}

\section{- SFIMT e o Teste Rápido de Inibição de Foco de Fluorescência - RFFIT}

Os resultados do RFFIT, considerado como teste padrão ouro para a detecção de anticorpos neutralizantes para o vírus da raiva pela OMS e OIE, foram considerados para a determinação da evidência de circulação viral entre os animais estudados.

Dentre as 139 amostras submetidas as duas técnicas, 50 (35,9\%) foram reagentes para o SFIMT e $15(10,8 \%)$ reagentes para o RFFIT, em ambas o ponto de corte foi estabelecido como o correspondente a maior diluição com detecção de anticorpos neutralizantes (Tabela 12).

O Coeficiente Kappa foi de 0,68, indicando boa concordância entre os testes. A sensibilidade $=86 \%$ e a especificidade $=70 \%$.

Tabela 12- Resultados do SFIMT*, segundo os resultados do RFFIT*, para a detecção de anticorpos neutralizantes para o vírus da raiva em mamíferos silvestres provenientes de área de Mata Atlântica nativa no litoral Norte do Estado de São Paulo, Brasil. Junho de 2012

\begin{tabular}{cccc|c}
\multicolumn{5}{c}{ SFIMT } \\
\hline \multirow{2}{*}{ RFFIT } & Positivo & Negativo & Total \\
& Positivo & 13 & 02 & 15 \\
& Negativo & 37 & 87 & 124 \\
\hline & Total & 50 & 89 & 139 \\
\hline
\end{tabular}

Coeficiente Kappa $=0,68$, indicando boa concordância entre os testes. Sensibilidade $=86 \%$. Especificidade $=70 \%$.

SFIMT: Microteste simplificado de inibição da fluorescência

RFFIT: Teste rápido de inibição de foco de fluorescência

*: Número de animais com presença de anticorpos neutralizantes

Fonte: Araujo (2012) 


\subsection{Ensaio Imunoenzimático - “Enzime Linked Immunosorbent Assay” - ELISA}

Dentre as 206 amostras submetidas a técnica de SFIMT, 177 (85.9\% do total de animais capturados) foram submetidas a prova de ELISA devido a quantidade insuficiente de soro das 29 amostras restantes. Apenas duas amostras $(1,13 \%)$ apresentaram resultados positivos pela técnica, a amostra FA2474 proveniente de um macaco prego e com título negativo para SFIMT e a amostra FA2447 proveniente de um gambá e com titulo 1,00UI/mL para SFIMT.

A figura 27 apresenta uma das placas de ELISA utilizadas para os soros deste estudo.

Figura 27- Placa de ELISA para a detecção de anticorpos contra o vírus da raiva em mamíferos silvestres provenientes de Mata Atlântica nativa no litoral Norte do Estado de São Paulo, Brasil. Junho de 2012

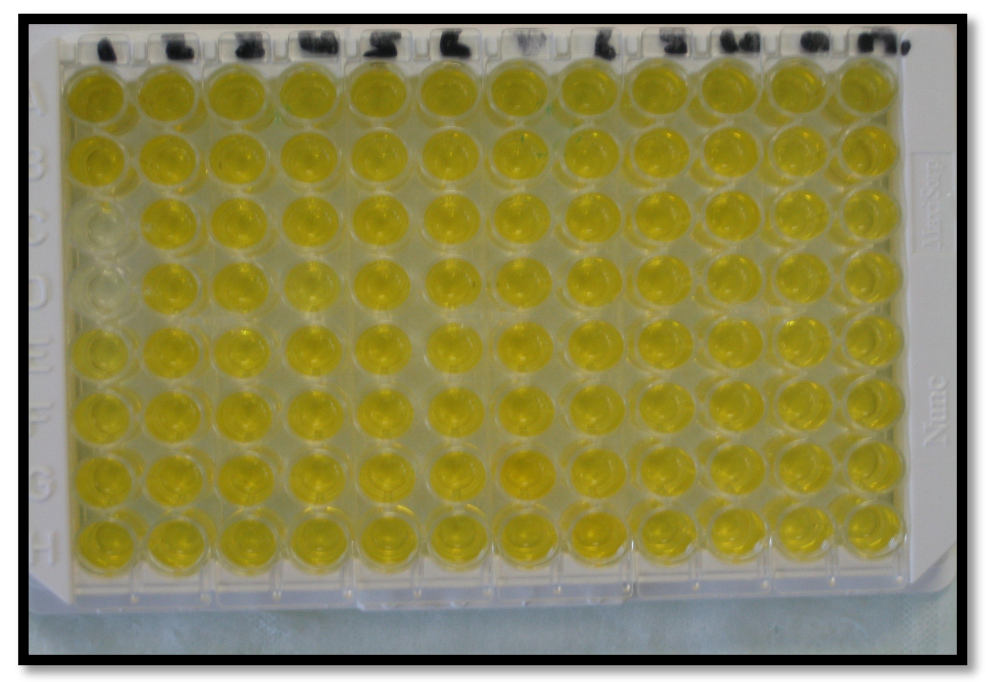

Fonte: Araujo (2012)

O quadro 01 apresenta a identificação, espécie animal, resultado da SFIMT, resultado da RFFIT, resultado do ELISA, gênero e idade de todas as amostras de soro obtidas dos animais do estudo. 
Quadro 1 Identificação, espécie, gênero, idade e resultados dos testes de SFIMT, RFFIT e ELISA para a detecção de anticorpos contra o vírus da raiva em mamíferos silvestres provenientes de área de Mata Atlântica nativa no litoral Norte do Es tado de São Paulo, Brasil. Junho de 2012

continua

\begin{tabular}{|c|c|c|c|c|c|c|c|}
\hline & Identificação & Animal & SFIMT & RFFIT & ELISA & Gênero & Idade \\
\hline 1 & RSL3105 & Gambá & $<0,16 \mathrm{UI} / \mathrm{mL}$ & $=0,08 \mathrm{UI} / \mathrm{mL}$ & $\mathrm{N}$ & $\mathrm{M}$ & $\mathrm{A}$ \\
\hline 2 & RSL5752 & Gambá & $<0,16 \mathrm{UI} / \mathrm{mL}$ & $=0,08 \mathrm{UI} / \mathrm{mL}$ & $\mathrm{N}$ & $\mathrm{M}$ & $\mathrm{J}$ \\
\hline 3 & RSL3405 & Cuica & $<0,16 \mathrm{UI} / \mathrm{mL}$ & $=0,08 \mathrm{UI} / \mathrm{mL}$ & $\mathrm{N}$ & $\mathrm{M}$ & A \\
\hline 4 & FA1857 & Gambá & $=0,16 \mathrm{UI} / \mathrm{mL}$ & $=0,08 \mathrm{UI} / \mathrm{mL}$ & $\mathrm{N}$ & $\mathrm{M}$ & $\mathrm{J}$ \\
\hline 5 & FA1858 & Gambá & $<0,16 \mathrm{UI} / \mathrm{mL}$ & $=0,08 \mathrm{UI} / \mathrm{mL}$ & $\mathrm{N}$ & $\mathrm{M}$ & $\mathrm{J}$ \\
\hline 6 & FA1856 & Gambá & $<0,16 \mathrm{UI} / \mathrm{mL}$ & NR & NR & $\mathrm{F}$ & A \\
\hline 7 & FA1862 & Gambá & $=0,16 \mathrm{UI} / \mathrm{mL}$ & $=0,08 \mathrm{UI} / \mathrm{mL}$ & $\mathrm{N}$ & $\mathrm{M}$ & $\mathrm{J}$ \\
\hline 8 & FA1863 & Gambá & $=0,16 \mathrm{UI} / \mathrm{mL}$ & $=0,12 \mathrm{UI} / \mathrm{mL}$ & $\mathrm{N}$ & $\mathrm{M}$ & $\mathrm{A}$ \\
\hline 9 & FA1883 & Macaco prego & $=0,51 \mathrm{UI} / \mathrm{mL}$ & NR & NR & $\mathrm{M}$ & $\mathrm{J}$ \\
\hline 10 & FA1887 & Macaco prego & $=0,33 \mathrm{UI} / \mathrm{mL}$ & NR & NR & $\mathrm{M}$ & $\mathrm{J}$ \\
\hline 11 & FA1897 & Gambá & $<0,16 \mathrm{UI} / \mathrm{mL}$ & NR & NR & $\mathrm{M}$ & $\mathrm{A}$ \\
\hline 12 & FA1906 & Jaguatirica & $=0,16 \mathrm{UI} / \mathrm{mL}$ & NR & NR & $\mathrm{F}$ & I \\
\hline 13 & RSL4194 & Tatu & $<0,16 \mathrm{UI} / \mathrm{mL}$ & NR & $\mathrm{N}$ & $\mathrm{M}$ & $\mathrm{J}$ \\
\hline 14 & FA2129 & Gambá & $<0,16 \mathrm{UI} / \mathrm{mL}$ & $=0,08 \mathrm{UI} / \mathrm{mL}$ & $\mathrm{N}$ & $\mathrm{M}$ & $\mathrm{A}$ \\
\hline 15 & FA2103 & Gambá & $<0,16 \mathrm{UI} / \mathrm{mL}$ & $=0,08 \mathrm{UI} / \mathrm{mL}$ & $\mathrm{N}$ & $\mathrm{M}$ & $\mathrm{A}$ \\
\hline 16 & FA2124 & Gambá & $=1,00 \mathrm{UI} / \mathrm{mL}$ & $=0,08 \mathrm{UI} / \mathrm{mL}$ & $\mathrm{N}$ & $\mathrm{M}$ & $\mathrm{A}$ \\
\hline 17 & RSL4214 & Tatu & $=0,16 \mathrm{UI} / \mathrm{mL}$ & $=0,08 \mathrm{UI} / \mathrm{mL}$ & $\mathrm{N}$ & $\mathrm{M}$ & $\mathrm{I}$ \\
\hline 18 & FA2084 & Gambá & $<0,16 \mathrm{UI} / \mathrm{mL}$ & $=0,08 \mathrm{UI} / \mathrm{mL}$ & $\mathrm{N}$ & $\mathrm{M}$ & $\mathrm{A}$ \\
\hline 19 & RSL4239 & Gambá & $<0,16 \mathrm{UI} / \mathrm{mL}$ & $=0,08 \mathrm{UI} / \mathrm{mL}$ & $\mathrm{N}$ & $\mathrm{M}$ & $\mathrm{J}$ \\
\hline 20 & RSL4209 & Tamanduá & $=0,16 \mathrm{UI} / \mathrm{mL}$ & NR & $\mathrm{N}$ & $\mathrm{F}$ & $\mathrm{J}$ \\
\hline 21 & FA2113 & Gambá & $=0,5 \mathrm{UI} / \mathrm{mL}$ & $=0,08 \mathrm{UI} / \mathrm{mL}$ & $\mathrm{N}$ & $\mathrm{M}$ & $\mathrm{A}$ \\
\hline 22 & FA2120 & Gambá & $=0,16 \mathrm{UI} / \mathrm{mL}$ & $=0,08 \mathrm{UI} / \mathrm{mL}$ & $\mathrm{N}$ & $\mathrm{M}$ & $\mathrm{A}$ \\
\hline 23 & RSL4171 & Gambá & $=0,16 \mathrm{U} / \mathrm{mL}$ & $=0,08 \mathrm{UI} / \mathrm{mL}$ & $\mathrm{N}$ & $\mathrm{M}$ & $\mathrm{A}$ \\
\hline 24 & RSL4229 & Gambá & $=0,66 \mathrm{UI} / \mathrm{mL}$ & $=0,08 \mathrm{UI} / \mathrm{mL}$ & $\mathrm{N}$ & $\mathrm{M}$ & $\mathrm{A}$ \\
\hline 25 & RSL4222 & Gambá & $<0,16 \mathrm{UI} / \mathrm{mL}$ & $=0,08 \mathrm{UI} / \mathrm{mL}$ & $\mathrm{N}$ & $\mathrm{M}$ & $\mathrm{J}$ \\
\hline 26 & RSL4215 & Gambá & $<0,16 \mathrm{UI} / \mathrm{mL}$ & $=0,08 \mathrm{UI} / \mathrm{mL}$ & $\mathrm{N}$ & $\mathrm{M}$ & $\mathrm{J}$ \\
\hline 27 & FA2078 & Gambá & $=1,00 \mathrm{UI} / \mathrm{mL}$ & $=0,19 \mathrm{UI} / \mathrm{mL}$ & $\mathrm{N}$ & $\mathrm{M}$ & $\mathrm{A}$ \\
\hline 28 & FA2114 & Gambá & $<0,16 \mathrm{UI} / \mathrm{mL}$ & $=0,08 \mathrm{UI} / \mathrm{mL}$ & $\mathrm{N}$ & $\mathrm{M}$ & $\mathrm{A}$ \\
\hline 29 & RSL4232 & Quati & $=1,00 \mathrm{UI} / \mathrm{mL}$ & $=0,20 \mathrm{UI} / \mathrm{mL}$ & $\mathrm{N}$ & $\mathrm{M}$ & $\mathrm{A}$ \\
\hline 30 & RSL4270 & Tatu & $<0,16 \mathrm{UI} / \mathrm{mL}$ & NR & $\mathrm{N}$ & $\mathrm{M}$ & $\mathrm{A}$ \\
\hline 31 & RSL4235 & Gambá & $<0,16 \mathrm{UI} / \mathrm{mL}$ & NR & $\mathrm{N}$ & $\mathrm{M}$ & $\mathrm{J}$ \\
\hline 32 & RSL4103 & Tatu & $=0,25 \mathrm{UI} / \mathrm{mL}$ & $=0,08 \mathrm{UI} / \mathrm{mL}$ & $\mathrm{N}$ & $\mathrm{M}$ & $\mathrm{A}$ \\
\hline
\end{tabular}

SFIMT: Microteste simplificado de inibição da fluorescência

RFFIT: Teste rápido de inibição de foco da fluorescência

ELISA: Ensaio imunoenzimático

FA: Fazenda Acaraú (área de soltura)

RSL: Riviera de SãoLourenço (área de construção de condomínio residencial)

N: Negativo

P: Positivo

NR: Não realizado

M: Macho

F: Fêmea

A: Adulto

J: Joven

I: Indeterminado

Fonte: Araujo (2012) 
Quadro 1 Identificação, espécie, gênero, idade e resultados dos testes de SFIMT, RFFIT e ELISA para a detecção de anticorpos contra o vírus da raiva em mamíferos silvestres provenientes de área de Mata Atlântica nativa no litoral Norte do Es tado de São Paulo, Brasil. Junho de 2012

continuação

\begin{tabular}{|c|c|c|c|c|c|c|c|}
\hline & Identificação & Animal & SFIMT & RFFIT & ELISA & Gênero & Idade \\
\hline 33 & FA2105 & Gambá & $<0,16 \mathrm{UI} / \mathrm{mL}$ & $=0,08 \mathrm{UI} / \mathrm{mL}$ & $\mathrm{N}$ & $\mathrm{F}$ & A \\
\hline 34 & FA2088 & Gambá & $<0,16 \mathrm{UI} / \mathrm{mL}$ & $=0,08 \mathrm{UI} / \mathrm{mL}$ & $\mathrm{N}$ & $\mathrm{M}$ & $\mathrm{A}$ \\
\hline 35 & RSL4254 & Gambá & $=0,16 \mathrm{UI} / \mathrm{mL}$ & $=0,08 \mathrm{UI} / \mathrm{mL}$ & $\mathrm{N}$ & $\mathrm{M}$ & $\mathrm{A}$ \\
\hline 36 & FA2049 & Gambá & $=0,33 \mathrm{UI} / \mathrm{mL}$ & $=0,08 \mathrm{UI} / \mathrm{mL}$ & $\mathrm{N}$ & $\mathrm{F}$ & $\mathrm{A}$ \\
\hline 37 & FA2038 & Gambá & $=0,16 \mathrm{UI} / \mathrm{mL}$ & $=0,08 \mathrm{UI} / \mathrm{mL}$ & $\mathrm{N}$ & $\mathrm{F}$ & I \\
\hline 38 & FA2046 & Gambá & $=0,50 \mathrm{UI} / \mathrm{mL}$ & $=0,08 \mathrm{UI} / \mathrm{mL}$ & $\mathrm{N}$ & $\mathrm{M}$ & $\mathrm{A}$ \\
\hline 39 & RSL4158 & Gambá & $=0,25 \mathrm{UI} / \mathrm{mL}$ & $=0,08 \mathrm{UI} / \mathrm{mL}$ & $\mathrm{N}$ & $\mathrm{F}$ & $\mathrm{A}$ \\
\hline 40 & FA2014 & Gambá & $=0,50 \mathrm{UI} / \mathrm{mL}$ & $=0,20 \mathrm{UI} / \mathrm{mL}$ & $\mathrm{N}$ & $\mathrm{M}$ & $\mathrm{A}$ \\
\hline 41 & RSL4104 & Tatu & $=0,25 \mathrm{UI} / \mathrm{mL}$ & $=0,08 \mathrm{UI} / \mathrm{mL}$ & $\mathrm{N}$ & $\mathrm{I}$ & I \\
\hline 42 & RSL4423 & Rato silvestre & $<0,16 \mathrm{UI} / \mathrm{mL}$ & NR & $\mathrm{N}$ & $\mathrm{M}$ & $\mathrm{J}$ \\
\hline 43 & RSL4499 & Gambá & $<0,25 \mathrm{UI} / \mathrm{mL}$ & $=0,08 \mathrm{UI} / \mathrm{mL}$ & $\mathrm{N}$ & $\mathrm{F}$ & $\mathrm{J}$ \\
\hline 44 & RSL4454 & Macaco prego & $<0,25 \mathrm{UI} / \mathrm{mL}$ & NR & NR & $\mathrm{M}$ & $\mathrm{J}$ \\
\hline 45 & RSL4436 & Gambá & $=0,25 \mathrm{UI} / \mathrm{mL}$ & $=0,08 \mathrm{UI} / \mathrm{mL}$ & $\mathrm{N}$ & $\mathrm{M}$ & $\mathrm{J}$ \\
\hline 46 & RSL4483 & Gambá & $<0,25 \mathrm{UI} / \mathrm{mL}$ & $=0,08 \mathrm{UI} / \mathrm{mL}$ & $\mathrm{N}$ & $\mathrm{M}$ & $J$ \\
\hline 47 & RSL4484 & Gambá & $<0,25 \mathrm{UI} / \mathrm{mL}$ & $=0,08 \mathrm{UI} / \mathrm{mL}$ & $\mathrm{N}$ & M & A \\
\hline 48 & RSL4467 & Rato silvestre & $<0,25 \mathrm{UI} / \mathrm{mL}$ & $=0,08 \mathrm{UI} / \mathrm{mL}$ & $\mathrm{N}$ & I & I \\
\hline 49 & RSL4492 & Gambá & $<0,25 \mathrm{UI} / \mathrm{mL}$ & $=0,08 \mathrm{UI} / \mathrm{mL}$ & $\mathrm{N}$ & $\mathrm{F}$ & $\mathrm{A}$ \\
\hline 50 & FA2419 & Gambá & $<0,25 \mathrm{UI} / \mathrm{mL}$ & NR & $\mathrm{N}$ & $\mathrm{M}$ & A \\
\hline 51 & FA2417 & Gambá & $<0,25 \mathrm{UI} / \mathrm{mL}$ & NR & $\mathrm{N}$ & $\mathrm{F}$ & $\mathrm{A}$ \\
\hline 52 & FA2416 & Gambá & $<0,25 \mathrm{UI} / \mathrm{mL}$ & $=0,08 \mathrm{UI} / \mathrm{mL}$ & $\mathrm{N}$ & $\mathrm{F}$ & $\mathrm{A}$ \\
\hline 53 & FA2326 & Macaco prego & $<0,25 \mathrm{UI} / \mathrm{mL}$ & NR & $\mathrm{N}$ & $\mathrm{M}$ & $\mathrm{J}$ \\
\hline 54 & FA2329 & Gambá & $<0,25 \mathrm{UI} / \mathrm{mL}$ & NR & $\mathrm{N}$ & $\mathrm{F}$ & $\mathrm{A}$ \\
\hline 55 & RSL2275 & Quati & $<0,25 \mathrm{UI} / \mathrm{mL}$ & NR & NR & $\mathrm{M}$ & $\mathrm{J}$ \\
\hline 56 & RSL4435 & Gambá & $<0,25 \mathrm{UI} / \mathrm{mL}$ & $=0,08 \mathrm{UI} / \mathrm{mL}$ & $\mathrm{N}$ & $\mathrm{F}$ & $\mathrm{A}$ \\
\hline 57 & RSL4364 & Gambá & $<0,25 \mathrm{UI} / \mathrm{mL}$ & $=0,08 \mathrm{UI} / \mathrm{mL}$ & $\mathrm{N}$ & $\mathrm{M}$ & A \\
\hline 58 & FA2266 & Macaco prego & $=0,50 \mathrm{UI} / \mathrm{mL}$ & $=0,08 \mathrm{UI} / \mathrm{mL}$ & NR & $\mathrm{F}$ & I \\
\hline 59 & RSL4396 & Gambá & $<0,25 \mathrm{UI} / \mathrm{mL}$ & $=0,08 \mathrm{UI} / \mathrm{mL}$ & $\mathrm{N}$ & $\mathrm{F}$ & $\mathrm{J}$ \\
\hline 60 & FA2321 & Gambá & $<0,25 \mathrm{UI} / \mathrm{mL}$ & NR & $\mathrm{N}$ & $\mathrm{F}$ & A \\
\hline 61 & FA2267 & Macaco prego & $=0,37 \mathrm{UI} / \mathrm{mL}$ & $=0,33 \mathrm{UI} / \mathrm{mL}$ & $\mathrm{N}$ & $\mathrm{M}$ & I \\
\hline 62 & FA2260 & Macaco prego & $<0,25 \mathrm{UI} / \mathrm{mL}$ & NR & $\mathrm{N}$ & $\mathrm{M}$ & $\mathrm{A}$ \\
\hline 63 & RSL4401 & Macaco prego & $<0,25 \mathrm{UI} / \mathrm{mL}$ & NR & NR & $\mathrm{F}$ & $\mathrm{A}$ \\
\hline 64 & RSL4457 & Rato do mato & $<0,25 \mathrm{UI} / \mathrm{mL}$ & NR & NR & $\mathrm{M}$ & I \\
\hline 65 & FA2365 & Gambá & $<0,25 \mathrm{UI} / \mathrm{mL}$ & $=0,08 \mathrm{UI} / \mathrm{mL}$ & $\mathrm{N}$ & $\mathrm{M}$ & $\mathrm{J}$ \\
\hline 66 & RSL4434 & Macaco prego & $<0,25 \mathrm{UI} / \mathrm{mL}$ & NR & NR & $\mathrm{I}$ & $\mathrm{J}$ \\
\hline 67 & FA2276 & Quati & $<0,25 \mathrm{UI} / \mathrm{mL}$ & NR & $\mathrm{N}$ & $\mathrm{M}$ & $\mathrm{J}$ \\
\hline 68 & RSL4393 & Tatu & $<0,25 \mathrm{UI} / \mathrm{mL}$ & NR & NR & $\mathrm{F}$ & $\mathrm{A}$ \\
\hline 69 & FA2234 & Macaco prego & $<0,25 \mathrm{UI} / \mathrm{mL}$ & NR & $\mathrm{N}$ & $\mathrm{M}$ & $\mathrm{J}$ \\
\hline 70 & FA2254 & Gambá & $<0,25 \mathrm{UI} / \mathrm{mL}$ & $=0,08 \mathrm{UI} / \mathrm{mL}$ & $\mathrm{N}$ & $\mathrm{F}$ & $\mathrm{A}$ \\
\hline 71 & FA2309 & Gambá & $<0,25 \mathrm{UI} / \mathrm{mL}$ & NR & $\mathrm{N}$ & $\mathrm{F}$ & $\mathrm{A}$ \\
\hline 72 & RSL4403 & Macaco prego & $<0,25 \mathrm{UI} / \mathrm{mL}$ & NR & $\mathrm{N}$ & $\mathrm{F}$ & A \\
\hline 73 & RSL4392 & Macaco prego & $<0,25 \mathrm{UI} / \mathrm{mL}$ & NR & $\mathrm{N}$ & $\mathrm{F}$ & $\mathrm{A}$ \\
\hline 74 & RSL4371 & Gambá & $<0,25 \mathrm{UI} / \mathrm{mL}$ & $=0,08 \mathrm{UI} / \mathrm{mL}$ & $\mathrm{N}$ & $\mathrm{F}$ & $\mathrm{A}$ \\
\hline 75 & FA2355 & Gambá & $<0,25 \mathrm{UI} / \mathrm{mL}$ & $=0,08 \mathrm{UI} / \mathrm{mL}$ & $\mathrm{N}$ & $\mathrm{F}$ & A \\
\hline 76 & FA2277 & Quati & $=0,37 \mathrm{UI} / \mathrm{mL}$ & $=0,12 \mathrm{UI} / \mathrm{mL}$ & $\mathrm{N}$ & $\mathrm{F}$ & $\mathrm{A}$ \\
\hline 77 & RSL4402 & Macaco prego & $<0,25 \mathrm{UI} / \mathrm{mL}$ & NR & NR & $\mathrm{F}$ & $\mathrm{A}$ \\
\hline 78 & RSL4400 & Macaco prego & $<0,25 \mathrm{UI} / \mathrm{mL}$ & NR & NR & $\mathrm{M}$ & A \\
\hline
\end{tabular}


Quadro 1 Identificação, espécie, gênero, idade e resultados dos testes de SFIMT, RFFIT e ELISA para a detecção de anticorpos contra o vírus da raiva em mamíferos silvestres provenientes de área de Mata Atlântica nativa no litoral Norte do Es tado de São Paulo, Brasil. Junho de 2012

continuação

\begin{tabular}{|c|c|c|c|c|c|c|c|}
\hline & Identificação & Animal & SFIMT & RFFIT & ELISA & Gênero & Idade \\
\hline 79 & FA2124 & Gambá & $<0,25 \mathrm{UI} / \mathrm{mL}$ & $=0,08 \mathrm{UI} / \mathrm{mL}$ & $\mathrm{N}$ & $\mathrm{M}$ & A \\
\hline 80 & FA4390 & Gambá & $<0,25 \mathrm{UI} / \mathrm{mL}$ & $=0,12 \mathrm{UI} / \mathrm{mL}$ & $\mathrm{N}$ & $\mathrm{M}$ & $\mathrm{J}$ \\
\hline 81 & FA2223 & Gambá & $<0,25 \mathrm{UI} / \mathrm{mL}$ & $=0,08 \mathrm{UI} / \mathrm{mL}$ & $\mathrm{N}$ & $\mathrm{M}$ & A \\
\hline 82 & FA1215 & Jaguatirica & $<0,25 \mathrm{UI} / \mathrm{mL}$ & $=0,08 \mathrm{UI} / \mathrm{mL}$ & NR & $\mathrm{F}$ & $\mathrm{A}$ \\
\hline 83 & RSL4278 & Gambá & $<0,25 \mathrm{UI} / \mathrm{mL}$ & $=0,08 \mathrm{UI} / \mathrm{mL}$ & $\mathrm{N}$ & $\mathrm{M}$ & $\mathrm{J}$ \\
\hline 84 & FA3584 & Gambá & $<0,25 \mathrm{UI} / \mathrm{mL}$ & $=0,12 \mathrm{UI} / \mathrm{mL}$ & $\mathrm{N}$ & $\mathrm{M}$ & $\mathrm{J}$ \\
\hline 85 & FA2157 & Macaco prego & $<0,25 \mathrm{UI} / \mathrm{mL}$ & NR & NR & $\mathrm{M}$ & $\mathrm{A}$ \\
\hline 86 & RSL4268 & Tatu & $<0,25 \mathrm{UI} / \mathrm{mL}$ & $=0,08 \mathrm{UI} / \mathrm{mL}$ & $\mathrm{N}$ & $\mathrm{M}$ & $\mathrm{J}$ \\
\hline 87 & RSL4066 & Cachorro do mat & $=0,25 \mathrm{UI} / \mathrm{mL}$ & NR & $\mathrm{N}$ & I & I \\
\hline 88 & FA2159 & Macaco prego & $<0,25 \mathrm{UI} / \mathrm{mL}$ & NR & NR & I & I \\
\hline 89 & FA2169 & Gambá & $<0,25 \mathrm{UI} / \mathrm{mL}$ & $=0,08 \mathrm{UI} / \mathrm{mL}$ & $\mathrm{N}$ & $\mathrm{M}$ & $J$ \\
\hline 90 & FA2192 & Gambá & $<0,25 \mathrm{UI} / \mathrm{mL}$ & $=0,08 \mathrm{UI} / \mathrm{mL}$ & $\mathrm{N}$ & M & A \\
\hline 91 & FA2490 & Gambá & $<0,16 \mathrm{UI} / \mathrm{mL}$ & $=0,08 \mathrm{UI} / \mathrm{mL}$ & $\mathrm{N}$ & $\mathrm{M}$ & A \\
\hline 92 & RSL4564 & Gambá & $=0,33 \mathrm{UI} / \mathrm{mL}$ & $=0,16 \mathrm{UI} / \mathrm{mL}$ & $\mathrm{N}$ & $\mathrm{M}$ & $\mathrm{A}$ \\
\hline 93 & FA2466 & Gambá & $<0,16 \mathrm{UI} / \mathrm{mL}$ & $=0,08 \mathrm{UI} / \mathrm{mL}$ & $\mathrm{N}$ & $\mathrm{F}$ & I \\
\hline 94 & RSL4559 & Gambá & $<0,16 \mathrm{UI} / \mathrm{mL}$ & NR & $\mathrm{N}$ & $\mathrm{M}$ & $\mathrm{A}$ \\
\hline 95 & RSL4560 & Gambá & $=0,33 \mathrm{UI} / \mathrm{mL}$ & NR & $\mathrm{N}$ & $\mathrm{M}$ & $\mathrm{J}$ \\
\hline 96 & FA2471 & Gambá & $<0,16 \mathrm{UI} / \mathrm{mL}$ & $=0,08 \mathrm{UI} / \mathrm{mL}$ & $\mathrm{N}$ & $\mathrm{M}$ & $\mathrm{J}$ \\
\hline 97 & FA2474 & Macaco prego & $<0,16 \mathrm{UI} / \mathrm{mL}$ & $=0,08 \mathrm{UI} / \mathrm{mL}$ & $\mathrm{P}$ & $\mathrm{F}$ & $\mathrm{A}$ \\
\hline 98 & FA2468 & Gambá & $<0,16 \mathrm{U} / \mathrm{mL}$ & NR & $\mathrm{N}$ & $\mathrm{M}$ & $\mathrm{A}$ \\
\hline 99 & FA2503 & Gambá & $=0,25 \mathrm{UI} / \mathrm{mL}$ & NR & $\mathrm{N}$ & $\mathrm{M}$ & I \\
\hline 100 & FA2509 & Gambá & $<0,16 \mathrm{UI} / \mathrm{mL}$ & $=0,08 \mathrm{UI} / \mathrm{mL}$ & $\mathrm{N}$ & $\mathrm{M}$ & $\mathrm{A}$ \\
\hline 101 & FA2508 & Gambá & $=1,00 \mathrm{UI} / \mathrm{mL}$ & $=0,16 \mathrm{UI} / \mathrm{mL}$ & $\mathrm{N}$ & $\mathrm{F}$ & $\mathrm{A}$ \\
\hline 102 & RSL4592 & Gambá & $<0,16 \mathrm{UI} / \mathrm{mL}$ & $=0,08 \mathrm{UI} / \mathrm{mL}$ & $\mathrm{N}$ & $\mathrm{M}$ & $\mathrm{J}$ \\
\hline 103 & RSL4534 & Gambá & $<0,16 \mathrm{UI} / \mathrm{mL}$ & $=0,08 \mathrm{UI} / \mathrm{mL}$ & $\mathrm{N}$ & $\mathrm{M}$ & A \\
\hline 104 & RSL4600 & Gambá & $<0,16 \mathrm{UI} / \mathrm{mL}$ & NR & $\mathrm{N}$ & $\mathrm{M}$ & $\mathrm{A}$ \\
\hline 105 & FA2447 & Gambá & $=1,00 \mathrm{UI} / \mathrm{mL}$ & $=1,00 \mathrm{UI} / \mathrm{mL}$ & $\mathrm{P}$ & $\mathrm{F}$ & $\mathrm{A}$ \\
\hline 106 & FA2439 & Macaco prego & $=0,66 \mathrm{UI} / \mathrm{mL}$ & $=0,08 \mathrm{UI} / \mathrm{mL}$ & $\mathrm{N}$ & $\mathrm{M}$ & A \\
\hline 107 & RSL4546 & Gambá & $<0,16 \mathrm{UI} / \mathrm{mL}$ & $=0,08 \mathrm{UI} / \mathrm{mL}$ & $\mathrm{N}$ & $\mathrm{M}$ & $\mathrm{J}$ \\
\hline 108 & RSL4566 & Gambá & $<0,16 \mathrm{UI} / \mathrm{mL}$ & $=0,08 \mathrm{UI} / \mathrm{mL}$ & $\mathrm{N}$ & $\mathrm{F}$ & $\mathrm{A}$ \\
\hline 109 & FA2528 & Mão Pelada & $=0,33 \mathrm{UI} / \mathrm{mL}$ & NR & $\mathrm{N}$ & $\mathrm{M}$ & $\mathrm{J}$ \\
\hline 110 & RSL4266 & Gambá & $<0,16 \mathrm{UI} / \mathrm{mL}$ & $=0,08 \mathrm{UI} / \mathrm{mL}$ & $\mathrm{N}$ & $\mathrm{F}$ & $\mathrm{J}$ \\
\hline 111 & RSL4513 & Gambá & $=0,66 \mathrm{UI} / \mathrm{mL}$ & $=0,08 \mathrm{UI} / \mathrm{mL}$ & $\mathrm{N}$ & $\mathrm{F}$ & $\mathrm{J}$ \\
\hline 112 & RSL4622 & Gambá & $=0,50 \mathrm{UI} / \mathrm{mL}$ & NR & NR & $\mathrm{M}$ & $\mathrm{A}$ \\
\hline 113 & RSL4535 & Macaco prego & $<0,16 \mathrm{UI} / \mathrm{mL}$ & $=0,08 \mathrm{UI} / \mathrm{mL}$ & $\mathrm{N}$ & $\mathrm{F}$ & $\mathrm{A}$ \\
\hline 114 & FA2500 & Gambá & $=0,16 \mathrm{UI} / \mathrm{mL}$ & NR & $\mathrm{N}$ & $\mathrm{F}$ & $\mathrm{A}$ \\
\hline 115 & FA4600 & Gambá & $=0,33 \mathrm{UI} / \mathrm{mL}$ & NR & $\mathrm{N}$ & $\mathrm{F}$ & A \\
\hline 116 & RSL4572 & Macaco prego & $<0,16 \mathrm{UI} / \mathrm{mL}$ & NR & $\mathrm{N}$ & $\mathrm{F}$ & $\mathrm{A}$ \\
\hline 117 & RSL4695 & Ratão do banhad & $<0,16 \mathrm{UI} / \mathrm{mL}$ & $=0,08 \mathrm{UI} / \mathrm{mL}$ & $\mathrm{N}$ & $\mathrm{M}$ & $\mathrm{A}$ \\
\hline 118 & FA2646 & Gambá & $<0,16 \mathrm{UI} / \mathrm{mL}$ & $=0,08 \mathrm{UI} / \mathrm{mL}$ & $\mathrm{N}$ & $\mathrm{M}$ & A \\
\hline 119 & RSL4687 & Gambá & $=0,16 \mathrm{UI} / \mathrm{mL}$ & $=0,08 \mathrm{UI} / \mathrm{mL}$ & $\mathrm{N}$ & $\mathrm{M}$ & $\mathrm{A}$ \\
\hline 120 & FA2666 & Gambá & $<0,16 \mathrm{UI} / \mathrm{mL}$ & $=0,08 \mathrm{UI} / \mathrm{mL}$ & $\mathrm{N}$ & $\mathrm{F}$ & $\mathrm{A}$ \\
\hline 121 & FA2541 & Gambá & $=0,25 \mathrm{UI} / \mathrm{mL}$ & $=0,11 \mathrm{UI} / \mathrm{mL}$ & NR & $\mathrm{M}$ & A \\
\hline 122 & FA2645 & Gambá & $=0,25 \mathrm{UI} / \mathrm{mL}$ & $=0,08 \mathrm{UI} / \mathrm{mL}$ & $\mathrm{N}$ & $\mathrm{M}$ & $\mathrm{A}$ \\
\hline 123 & FA2634 & Macaco prego & $<0,16 \mathrm{UI} / \mathrm{mL}$ & $=0,08 \mathrm{UI} / \mathrm{mL}$ & $\mathrm{N}$ & $\mathrm{M}$ & $\mathrm{A}$ \\
\hline 124 & FA4679 & Gambá & $<0,16 \mathrm{UI} / \mathrm{mL}$ & $=0,08 \mathrm{UI} / \mathrm{mL}$ & $\mathrm{N}$ & $\mathrm{M}$ & $\mathrm{J}$ \\
\hline
\end{tabular}


Quadro 1 Identificação, espécie, gênero, idade e resultados dos testes de SFIMT, RFFIT e ELISA para a detecção de anticorpos contra o vírus da raiva em mamíferos silvestres provenientes de área de Mata Atlântica nativa no litoral Norte do Es tado de São Paulo, Brasil. Junho de 2012

continuação

\begin{tabular}{|c|c|c|c|c|c|c|c|}
\hline & Identificação & Animal & SFIMT & RFFIT & ELISA & Gênero & Idade \\
\hline 125 & Enc1264 & Gambá & $<0,16 \mathrm{UI} / \mathrm{mL}$ & $=0,08 \mathrm{UI} / \mathrm{mL}$ & $\mathrm{N}$ & $\mathrm{M}$ & A \\
\hline 126 & FA2767 & Gambá & $<0,16 \mathrm{UI} / \mathrm{mL}$ & $=0,08 \mathrm{UI} / \mathrm{mL}$ & $\mathrm{N}$ & $\mathrm{M}$ & A \\
\hline 127 & RSL4764 & Gambá & $=0,22 \mathrm{UI} / \mathrm{mL}$ & $=0,08 \mathrm{UI} / \mathrm{mL}$ & $\mathrm{N}$ & $\mathrm{F}$ & $J$ \\
\hline 128 & FA2765 & Gambá & $=0,22 \mathrm{UI} / \mathrm{mL}$ & $=0,08 \mathrm{UI} / \mathrm{mL}$ & $\mathrm{N}$ & $\mathrm{M}$ & A \\
\hline 129 & FA2775 & Gambá & $<0,16 \mathrm{UI} / \mathrm{mL}$ & $=0,08 \mathrm{UI} / \mathrm{mL}$ & $\mathrm{N}$ & $\mathrm{M}$ & A \\
\hline 130 & RSL4761 & Gambá & $<0,16 \mathrm{UI} / \mathrm{mL}$ & $\mathrm{NR}$ & $\mathrm{N}$ & I & I \\
\hline 131 & FA2758 & Gambá & $<0,16 \mathrm{UI} / \mathrm{mL}$ & NR & $\mathrm{NR}$ & $\mathrm{M}$ & A \\
\hline 132 & RSL4741 & Gambá & $=0,33 \mathrm{UI} / \mathrm{mL}$ & NR & $\mathrm{N}$ & $\mathrm{F}$ & $\mathrm{A}$ \\
\hline 133 & RSL4788 & Gambá & $=0,22 \mathrm{UI} / \mathrm{mL}$ & NR & $\mathrm{N}$ & F & A \\
\hline 134 & RSL4780 & Gambá & $=0,50 \mathrm{UI} / \mathrm{mL}$ & $=0,16 \mathrm{UI} / \mathrm{mL}$ & $\mathrm{N}$ & $\mathrm{F}$ & A \\
\hline 135 & RSL4783 & Gambá & $<0,16 \mathrm{UI} / \mathrm{mL}$ & $=0,08 \mathrm{UI} / \mathrm{mL}$ & $\mathrm{N}$ & $\mathrm{F}$ & A \\
\hline 136 & RSL4787 & Gambá & $=0,22 \mathrm{UI} / \mathrm{mL}$ & $=0,08 \mathrm{UI} / \mathrm{mL}$ & $\mathrm{N}$ & F & A \\
\hline 137 & RSL4777 & Gambá & $=0,22 \mathrm{UI} / \mathrm{mL}$ & $=0,08 \mathrm{UI} / \mathrm{mL}$ & $\mathrm{N}$ & $\mathrm{M}$ & A \\
\hline 138 & RSL4784 & Gambá & $<0,16 \mathrm{UI} / \mathrm{mL}$ & $=0,08 \mathrm{UI} / \mathrm{mL}$ & $\mathrm{N}$ & $\mathrm{F}$ & $\mathrm{J}$ \\
\hline 139 & FA2755 & Gambá & $<0,16 \mathrm{UI} / \mathrm{mL}$ & $=0,08 \mathrm{UI} / \mathrm{mL}$ & $\mathrm{N}$ & $\mathrm{M}$ & A \\
\hline 140 & RSL4721 & Gambá & $<0,16 \mathrm{UI} / \mathrm{mL}$ & $=0,08 \mathrm{UI} / \mathrm{mL}$ & $\mathrm{N}$ & $\mathrm{M}$ & A \\
\hline 141 & FA2985 & Gambá & $<0,16 \mathrm{UI} / \mathrm{mL}$ & $=0,08 \mathrm{UI} / \mathrm{mL}$ & $\mathrm{N}$ & $\mathrm{F}$ & A \\
\hline 142 & RSL4797 & Gambá & $<0,16 \mathrm{UI} / \mathrm{mL}$ & $=0,08 \mathrm{UI} / \mathrm{mL}$ & $\mathrm{N}$ & $\mathrm{F}$ & $\mathrm{J}$ \\
\hline 143 & RSL442 & Gambá & $<0,16 \mathrm{UI} / \mathrm{mL}$ & $=0,08 \mathrm{UI} / \mathrm{mL}$ & $\mathrm{N}$ & $\mathrm{M}$ & A \\
\hline 144 & RSL4795 & Gambá & $=0,22 \mathrm{UI} / \mathrm{mL}$ & NR & $\mathrm{NR}$ & $\mathrm{M}$ & A \\
\hline 145 & RSL4792 & Gambá & $<0,16 \mathrm{UI} / \mathrm{mL}$ & $=0,08 \mathrm{UI} / \mathrm{mL}$ & $\mathrm{N}$ & $\mathrm{F}$ & A \\
\hline 146 & FA2940 & Gambá & $=0,16 \mathrm{UI} / \mathrm{mL}$ & $=0,14 \mathrm{UI} / \mathrm{mL}$ & $\mathrm{N}$ & $\mathrm{M}$ & A \\
\hline 147 & RSL4812 & Gambá & $<0,16 \mathrm{UI} / \mathrm{mL}$ & $=0,08 \mathrm{UI} / \mathrm{mL}$ & $\mathrm{N}$ & $\mathrm{I}$ & I \\
\hline 148 & FA3101 & Gambá & $<0,16 \mathrm{UI} / \mathrm{mL}$ & $=0,08 \mathrm{UI} / \mathrm{mL}$ & $\mathrm{N}$ & $\mathrm{M}$ & A \\
\hline 149 & FA2982 & Caititu & $=0,33 \mathrm{UI} / \mathrm{mL}$ & $=0,08 \mathrm{UI} / \mathrm{mL}$ & $\mathrm{N}$ & $\mathrm{F}$ & A \\
\hline 150 & FA2948 & Gambá & $<0,16 \mathrm{UI} / \mathrm{mL}$ & $=0,08 \mathrm{UI} / \mathrm{mL}$ & $\mathrm{N}$ & I & I \\
\hline 151 & RSL4804 & Gambá & $<0,16 \mathrm{UI} / \mathrm{mL}$ & $=0,08 \mathrm{UI} / \mathrm{mL}$ & $\mathrm{N}$ & I & I \\
\hline 152 & RSL4829 & Gambá & $<0,16 \mathrm{UI} / \mathrm{mL}$ & $=0,08 \mathrm{UI} / \mathrm{mL}$ & $\mathrm{N}$ & $\mathrm{F}$ & A \\
\hline 153 & FA3058 & Macaco prego & $<0,16 \mathrm{UI} / \mathrm{mL}$ & $=0,08 \mathrm{UI} / \mathrm{mL}$ & $\mathrm{N}$ & $\mathrm{F}$ & A \\
\hline 154 & FA3059 & Macaco prego & $<0,16 \mathrm{UI} / \mathrm{mL}$ & $=0,08 \mathrm{UI} / \mathrm{mL}$ & $\mathrm{N}$ & $\mathrm{F}$ & A \\
\hline 155 & FA3033 & Gambá & $<0,16 \mathrm{UI} / \mathrm{mL}$ & $=0,08 \mathrm{UI} / \mathrm{mL}$ & $\mathrm{N}$ & $\mathrm{M}$ & A \\
\hline 156 & FA3057 & Macaco prego & $<0,16 \mathrm{UI} / \mathrm{mL}$ & $=0,08 \mathrm{UI} / \mathrm{mL}$ & $\mathrm{N}$ & $\mathrm{F}$ & A \\
\hline 157 & FA3007 & Gambá & $<0,16 \mathrm{UI} / \mathrm{mL}$ & NR & $\mathrm{N}$ & $\mathrm{M}$ & $\mathrm{A}$ \\
\hline 158 & RSL4813 & Tatu & $<0,16 \mathrm{UI} / \mathrm{mL}$ & $=0,08 \mathrm{UI} / \mathrm{mL}$ & $\mathrm{N}$ & $\mathrm{M}$ & A \\
\hline 159 & FA3417 & Gambá & $=0,5 \mathrm{UI} / \mathrm{mL}$ & NR & $\mathrm{N}$ & $\mathrm{F}$ & A \\
\hline 160 & FA3446 & Macaco prego & $=0,5 \mathrm{UI} / \mathrm{mL}$ & NR & $\mathrm{N}$ & I & A \\
\hline 161 & FA3331 & Gambá & $=0,5 \mathrm{UI} / \mathrm{mL}$ & $=0,08 \mathrm{UI} / \mathrm{mL}$ & $\mathrm{N}$ & $\mathrm{F}$ & A \\
\hline 162 & FA3302 & Gambá & $=0,16 \mathrm{UI} / \mathrm{mL}$ & $=0,08 \mathrm{UI} / \mathrm{mL}$ & $\mathrm{N}$ & $\mathrm{F}$ & A \\
\hline 163 & FA3436 & Gambá & $<0,16 \mathrm{UI} / \mathrm{mL}$ & $=0,08 \mathrm{UI} / \mathrm{mL}$ & $\mathrm{N}$ & $\mathrm{F}$ & A \\
\hline 164 & FA3274 & Gambá & $<0,16 \mathrm{UI} / \mathrm{mL}$ & $=0,08 \mathrm{UI} / \mathrm{mL}$ & $\mathrm{N}$ & $\mathrm{F}$ & A \\
\hline 165 & FA3322 & Gambá & $=0,25 \mathrm{UI} / \mathrm{mL}$ & $=0,08 \mathrm{UI} / \mathrm{mL}$ & $\mathrm{N}$ & $\mathrm{F}$ & A \\
\hline 166 & FA3414 & Gambá & $=0,25 \mathrm{UI} / \mathrm{mL}$ & $=0,08 \mathrm{UI} / \mathrm{mL}$ & $\mathrm{N}$ & $\mathrm{F}$ & A \\
\hline 167 & FA1266 & Gato Maracajá & $<0,16 \mathrm{UI} / \mathrm{mL}$ & $=0,08 \mathrm{UI} / \mathrm{mL}$ & $\mathrm{N}$ & $\mathrm{M}$ & $\mathrm{A}$ \\
\hline 168 & RSL4838 & Gambá & $=0,33 \mathrm{UI} / \mathrm{mL}$ & $=0,11 \mathrm{UI} / \mathrm{mL}$ & $\mathrm{N}$ & $\mathrm{M}$ & A \\
\hline 169 & FA3687 & Gambá & $=0,16 \mathrm{UI} / \mathrm{mL}$ & $=0,08 \mathrm{UI} / \mathrm{mL}$ & $\mathrm{N}$ & $\mathrm{M}$ & A \\
\hline
\end{tabular}


Quadro 1 Identificação, espécie, gênero, idade e resultados dos testes de SFIMT, RFFIT e ELISA para a detecção de anticorpos contra o vírus da raiva em mamíferos silvestres provenientes de área de Mata Atlântica nativa no litoral Norte do Es tado de São Paulo, Brasil. Junho de 2012

conclusão

\begin{tabular}{|c|c|c|c|c|c|c|c|}
\hline & Identificação & Animal & SFIMT & RFFIT & ELISA & Gênero & Idade \\
\hline 170 & FA3696 & Macaco prego & $=0,33 \mathrm{UI} / \mathrm{mL}$ & NR & $\mathrm{N}$ & $\mathrm{M}$ & A \\
\hline 171 & FA3703 & Gambá & $=0,33 \mathrm{UI} / \mathrm{mL}$ & $=0,08 \mathrm{UI} / \mathrm{mL}$ & $\mathrm{N}$ & $\mathrm{M}$ & $\mathrm{A}$ \\
\hline 172 & FA3656 & Cotia & $=0,5 \mathrm{UI} / \mathrm{mL}$ & NR & NR & $\mathrm{F}$ & $\mathrm{A}$ \\
\hline 173 & FA3736 & Gambá & $=0,25 \mathrm{UI} / \mathrm{mL}$ & $=0,08 \mathrm{UI} / \mathrm{mL}$ & $\mathrm{N}$ & $\mathrm{M}$ & $\mathrm{A}$ \\
\hline 174 & FA3705 & Gambá & $=0,25 \mathrm{UI} / \mathrm{mL}$ & $=0,08 \mathrm{UI} / \mathrm{mL}$ & $\mathrm{N}$ & $\mathrm{M}$ & $\mathrm{A}$ \\
\hline 175 & FA3641 & Gambá & $=0,16 \mathrm{UI} / \mathrm{mL}$ & $=0,08 \mathrm{UI} / \mathrm{mL}$ & $\mathrm{N}$ & $\mathrm{M}$ & $\mathrm{A}$ \\
\hline 176 & FA3723 & Gambá & $<0,16 \mathrm{UI} / \mathrm{mL}$ & $=0,08 \mathrm{UI} / \mathrm{mL}$ & $\mathrm{N}$ & $\mathrm{M}$ & $\mathrm{A}$ \\
\hline 177 & FA3611 & Gambá & $=0,5 \mathrm{UI} / \mathrm{mL}$ & NR & $\mathrm{N}$ & $\mathrm{M}$ & $\mathrm{I}$ \\
\hline 178 & FA3820 & Macaco prego & $<0,22 \mathrm{UI} / \mathrm{mL}$ & $=0,08 \mathrm{UI} / \mathrm{mL}$ & $\mathrm{N}$ & $\mathrm{F}$ & $\mathrm{J}$ \\
\hline 179 & FA3825 & Macaco prego & $<0,22 \mathrm{UI} / \mathrm{mL}$ & $=0,08 \mathrm{UI} / \mathrm{mL}$ & $\mathrm{N}$ & $\mathrm{M}$ & $\mathrm{A}$ \\
\hline 180 & FA3823 & Macaco prego & $<0,22 \mathrm{UI} / \mathrm{mL}$ & NR & $\mathrm{N}$ & $\mathrm{M}$ & $\mathrm{A}$ \\
\hline 181 & FA3803 & Macaco prego & $<0,22 \mathrm{UI} / \mathrm{mL}$ & NR & NR & $\mathrm{M}$ & $\mathrm{J}$ \\
\hline 182 & FA3799 & Macaco prego & $<0,22 \mathrm{UI} / \mathrm{mL}$ & $=0,08 \mathrm{UI} / \mathrm{mL}$ & $\mathrm{N}$ & $\mathrm{F}$ & $\mathrm{A}$ \\
\hline 183 & FA3797 & Macaco prego & $<0,22 \mathrm{UI} / \mathrm{mL}$ & $=0,08 \mathrm{UI} / \mathrm{mL}$ & $\mathrm{N}$ & $\mathrm{F}$ & $\mathrm{A}$ \\
\hline 184 & FA3182 & Macaco prego & $<0,22 \mathrm{UI} / \mathrm{mL}$ & NR & $\mathrm{N}$ & $\mathrm{M}$ & $\mathrm{A}$ \\
\hline 185 & FA3178 & Gambá & $<0,22 \mathrm{UI} / \mathrm{mL}$ & $=0,08 \mathrm{UI} / \mathrm{mL}$ & $\mathrm{N}$ & $\mathrm{F}$ & $\mathrm{A}$ \\
\hline 186 & FA3744 & Jaguatirica & $<0,22 \mathrm{UI} / \mathrm{mL}$ & $=0,08 \mathrm{UI} / \mathrm{mL}$ & $\mathrm{N}$ & $\mathrm{F}$ & $\mathrm{A}$ \\
\hline 187 & RSL4835 & Gambá & $<0,22 \mathrm{UI} / \mathrm{mL}$ & NR & NR & $\mathrm{M}$ & $\mathrm{A}$ \\
\hline 188 & FA3798 & Macaco prego & $<0,22 \mathrm{UI} / \mathrm{mL}$ & NR & NR & $\mathrm{F}$ & $\mathrm{A}$ \\
\hline 189 & FA3480 & Gambá & $<0,22 \mathrm{UI} / \mathrm{mL}$ & NR & $\mathrm{N}$ & $\mathrm{F}$ & $\mathrm{A}$ \\
\hline 190 & RSL4142 & Gambá & $<0,22 \mathrm{UI} / \mathrm{mL}$ & NR & $\mathrm{N}$ & $\mathrm{M}$ & $\mathrm{A}$ \\
\hline 191 & FA2021 & Gambá & $<0,22 \mathrm{UI} / \mathrm{mL}$ & NR & $\mathrm{N}$ & $\mathrm{F}$ & $\mathrm{J}$ \\
\hline 192 & FA2026 & Gambá & $<0,22 \mathrm{UI} / \mathrm{mL}$ & $=0,08 \mathrm{UI} / \mathrm{mL}$ & $\mathrm{N}$ & $\mathrm{M}$ & $\mathrm{A}$ \\
\hline 193 & FA4223 & Gambá & $<0,22 \mathrm{UI} / \mathrm{mL}$ & $=0,08 \mathrm{UI} / \mathrm{mL}$ & $\mathrm{N}$ & $\mathrm{F}$ & $\mathrm{A}$ \\
\hline 194 & FA4211 & Macaco prego & $<0,22 \mathrm{UI} / \mathrm{mL}$ & NR & $\mathrm{N}$ & $\mathrm{M}$ & $\mathrm{J}$ \\
\hline 195 & FA4215 & Gambá & $<0,22 \mathrm{UI} / \mathrm{mL}$ & $=0,08 \mathrm{UI} / \mathrm{mL}$ & $\mathrm{N}$ & $\mathrm{M}$ & $\mathrm{A}$ \\
\hline 196 & FA4239 & Gambá & $=0,33 \mathrm{UI} / \mathrm{mL}$ & $=0,08 \mathrm{UI} / \mathrm{mL}$ & $\mathrm{N}$ & $\mathrm{F}$ & $\mathrm{A}$ \\
\hline 197 & FA4226 & Gambá & $<0,22 \mathrm{UI} / \mathrm{mL}$ & $=0,08 \mathrm{UI} / \mathrm{mL}$ & $\mathrm{N}$ & $\mathrm{F}$ & $\mathrm{A}$ \\
\hline 198 & FA4041 & Gambá & $=0,33 \mathrm{UI} / \mathrm{mL}$ & NR & NR & $\mathrm{I}$ & $\mathrm{I}$ \\
\hline 199 & FA4095 & Macaco prego & $=0,33 \mathrm{UI} / \mathrm{mL}$ & $=0,08 \mathrm{UI} / \mathrm{mL}$ & $\mathrm{N}$ & $\mathrm{F}$ & $\mathrm{A}$ \\
\hline 200 & FA4037 & Macaco prego & $<0,22 \mathrm{UI} / \mathrm{mL}$ & $=0,08 \mathrm{UI} / \mathrm{mL}$ & $\mathrm{N}$ & $\mathrm{M}$ & $\mathrm{A}$ \\
\hline 201 & FA4019 & Cotia & $<0,22 \mathrm{UI} / \mathrm{mL}$ & NR & NR & $\mathrm{F}$ & $\mathrm{A}$ \\
\hline 202 & FA4176 & Cotia & $<0,22 \mathrm{UI} / \mathrm{mL}$ & $=0,08 \mathrm{UI} / \mathrm{mL}$ & $\mathrm{N}$ & $\mathrm{F}$ & $\mathrm{A}$ \\
\hline 203 & FA4173 & Gambá & $<0,22 \mathrm{UI} / \mathrm{mL}$ & $=0,08 \mathrm{UI} / \mathrm{mL}$ & $\mathrm{N}$ & $\mathrm{M}$ & $\mathrm{A}$ \\
\hline 204 & FA4064 & Gambá & $<0,22 \mathrm{UI} / \mathrm{mL}$ & NR & NR & $\mathrm{F}$ & $\mathrm{A}$ \\
\hline 205 & FA4201 & Gambá & $<0,22 \mathrm{UI} / \mathrm{mL}$ & NR & $\mathrm{N}$ & $\mathrm{M}$ & $\mathrm{A}$ \\
\hline 206 & FA4175 & Gambá & $<0,22 \mathrm{UI} / \mathrm{mL}$ & NR & NR & $\mathrm{M}$ & $\mathrm{A}$ \\
\hline
\end{tabular}




\subsection{Imunofluorescência Direta - IFD, Inoculação Intrecerebral em Camundongos - IC e Reação em Cadeia pela Polimerase precedida de transcrição - RT- PCR}

Um total de 53 animais foi submetido a necrópsia para obtenção de amostras de sistema nervoso central para detecção do vírus da raiva. Essas amostras foram provenientes de 09 diferentes ordens animais, compreendendo 19 diferentes espécies, de mamíferos silvestres encontrados mortos na área de estudo e também em ruas e estradas da região. Todas as amostras apresentaram resultados negativos para as provas de Imunofluorescência Direta (IFD), Inoculação Intracerebral em Camundongos (IC) e Reação em Cadeia da Polimerase precedida de transcrição (RT-PCR).

A ordem animal predominante foi a Rodentia (ratos do mato, silvestre, doméstico e do banhado, esquilo, capivara -19 animais), seguida pela Didelphimorphia (gambá, cuíca - 11 animais) e Carnivora ( jaguatirica, cachorro do mato, quati, gato mourisco, gato do mato - 08 animais), e das ordens Primata (macaco-prego, bugio - 06 animais), Cingulata (tamanduá - 04 animais), Artiodactyla (veado - 03 animais), Pilosa (tatu - 01 animal) e Eurinaceomorpha (ouriço - 01 animal). A figura 28 representa a distribuição das ordens estudadas.

Figura 28- Divisão de acordo com a ordem animal dos animais encontrados mortos em área de Mata Atlântica Nativa no litoral Norte do Estado de São Paulo, Brasil. Junho de 2012

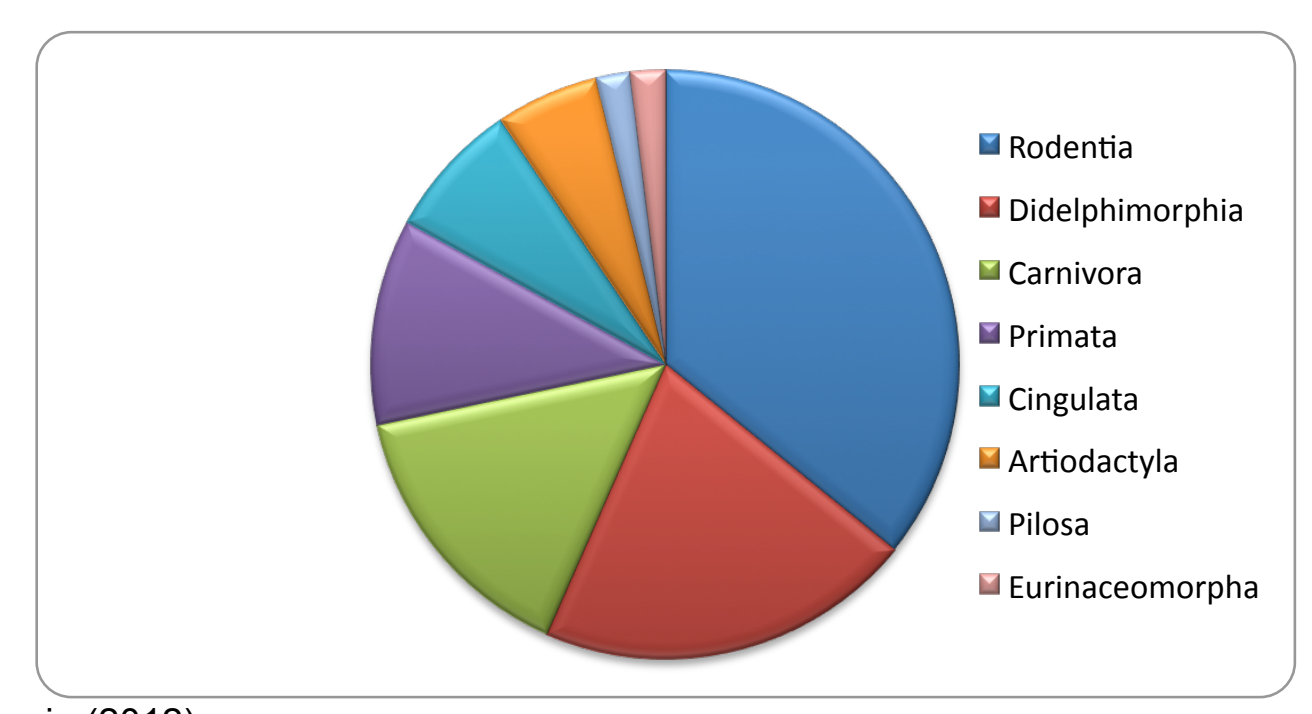

Fonte: Araujo (2012) 
Foram necropsiados e submetidos a técnicas para a detecção do vírus da raiva 10 gambás (Didelphis aurita), 01 cuíca (Metachirus opossum) 10 ratos silvestres (Oligoryzomys nigripes), 03 ratos domésticos (Rattus rattus), 01 rato do mato (Akodon cursor), 01 ratão do banhado (Myocastor coypus), 05 macacos-prego (Cebus apella), 01 bugio ruivo (Allouata clamitans), 04 tamanduás (Tamandua tetradactyla), 03 veados (Mazama americana), 02 jaguatiricas (Leopardus pardalis), 01 gato do mato (Leopardus tigrinus), 01 gato mourisco (Puma yaguarondi eysa), 03 quatis (Nasua nasua), 01 tatu (Dasypus novemcinctus), 01 ouriço (Erinaceus spp), 02 esquilos (Schiurus aestuans), 01 serelepe (Sciurus aestuans), 01 capivara (Hydrochorus hydrochaeri), 01 cachorro do mato (Cerdocyon thous).

A Tabela 13 apresenta a relação dos animais, espécies e número de indivíduos submetidos a detecção do vírus da raiva. 
Tabela 13- Quantidade, nome comum e espécie de amostras de SNC de mamíferos silvestres provenientes de área de Mata Atlântica Nativa no litoral Norte do Estado de São Paulo, submetidos a IFD, IC e RT-PCR para a detecção do vírus da raiva. São Paulo, junho de 2012

\begin{tabular}{ccc}
\hline Quantidade & Animal & Espécie \\
\hline 10 & Gambá & Didelphis aurita \\
10 & Rato Silvestre & Oligoryzomys nigripes \\
03 & Rato Doméstico & Rattus rattus \\
05 & Macaco Prego & Cebus apella \\
02 & Jaguatirica & Leopardus pardalis \\
03 & Veado & Mazama americana \\
01 & Cuíca & Metachirus opossum \\
01 & Tatu & Dasypus novemcinctus \\
04 & Tamanduá & Tamandua tetradactyla \\
01 & Ouriço & Erinaceus spp \\
02 & Esquilo & Schiurus vulgaris \\
03 & Quati & Nasua nasua \\
01 & Esquilo (serelepe) & Schiurus aestuans \\
01 & Rato da Mata & Akodon cursor \\
01 & Ratão do Banhado & Myocastor coypus \\
01 & Bugio Ruivo & Alouatta clamitans \\
01 & Gato Mourisco & Puma yaguarondi eysa \\
01 & Capivara & Hydrochorus hydrochaeri \\
01 & Cachorro do mato & Cerdocyon thous \\
01 & Gato do Mato & Leopardus tigrinus \\
\hline 53 & & \\
\hline
\end{tabular}

IFD: Imunofluorescência direta

IC: Inoculação intracerebral em camundongos

RT-PCR: Reação em cadeia pela polimerase precedida de transcrição

Fonte: Araujo (2012)

As figuras 29 e 30 demonstram a eletroforese de amostras cerebrais dos animais submetidas a RT-PCR com "primers" direcionados a amplificação da região $16 S$ ribossomal do RNA total extraído e de um fragmento da sequência de RNA responsável pela decodificação da Nucleoproteína do vírus da raiva 
Figura 29- Amplificação por meio de RT-PCR em amostras de SNC de mamíferos silvestres provenientes de área de Mata Atlântica nativa no litoral norte do Estado de São Paulo para a detecção da região $16 S$ do RNA extraído. São Paulo, junho de 2012

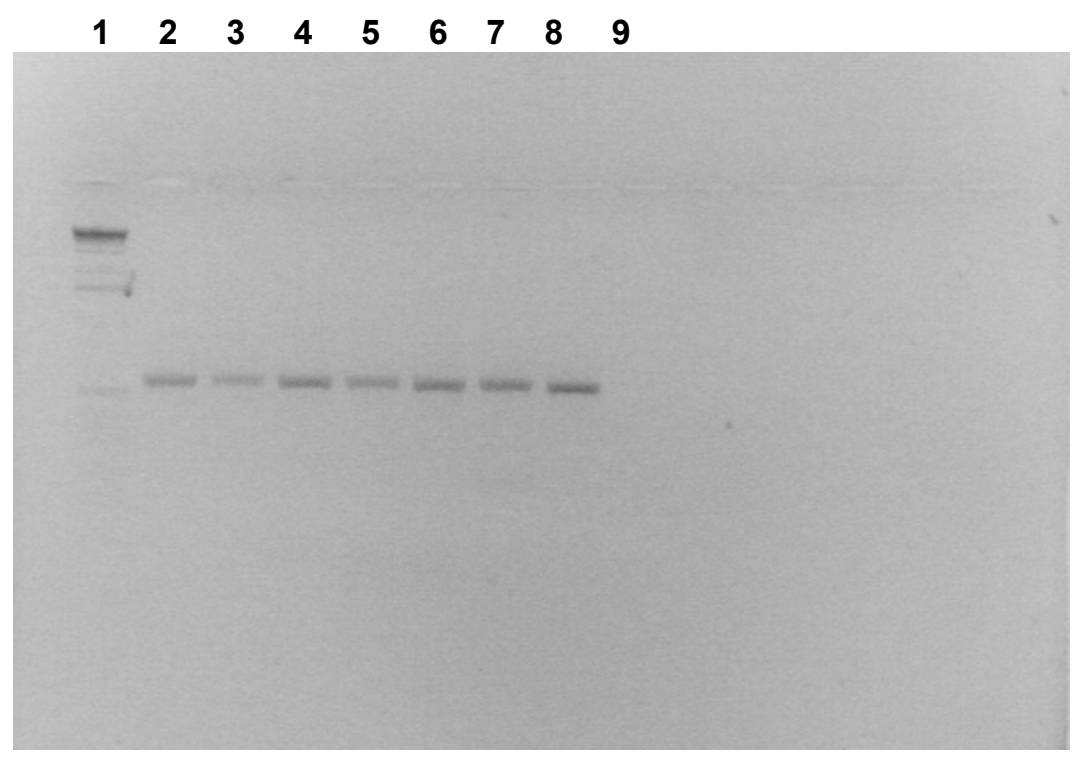

SNC: Sistema nervoso central

RT-PCR: Reação em cadeia pela polimerase precedida de transcrição

Coluna 1: Peso molecular (1kb); coluna 2: controle positivo $(500 \mathrm{pb})$; coluna 3: controle positivo; coluna 4: Tamanduá; coluna 5: ouriço; coluna 6: esquilo; coluna 7: quati; coluna 8: esquilo; coluna 9: controle negativo

Fonte: Araujo (2012) 
Figura 30-Amplificação por meio da RT-PCR de amostras de SNC mamíferos silvestres provenientes de área de Mata Atlântica nativa no litoral norte do Estado de São Paulo para detecção de fragmento da sequência de codificação da Nucleoproteína do vírus da raiva. São Paulo, junho de 2012

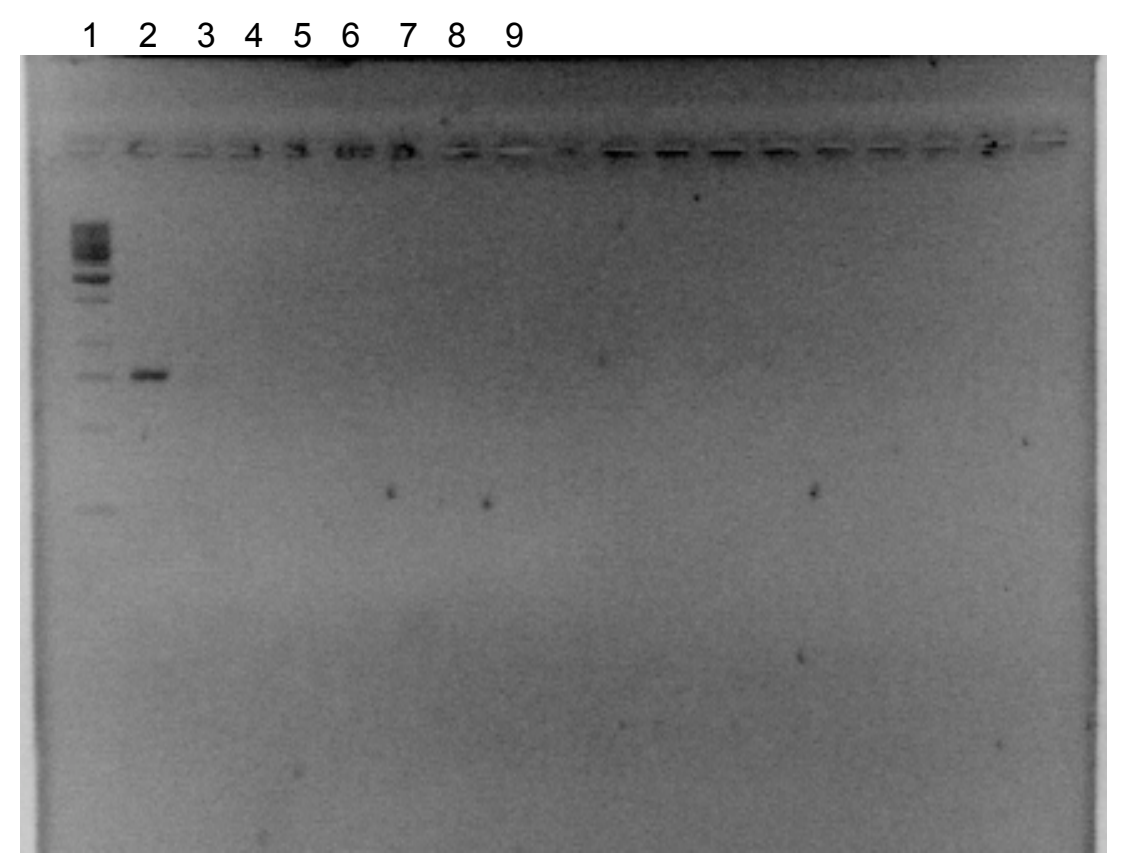

SNC: Sistema nervoso central

RT-PCR: Reação em cadeia pela polimerase precedida de transcrição

Legenda: Coluna 1: Peso molecular $(1 \mathrm{~kb})$; coluna 2: controle positivo $(765 \mathrm{pb})$; coluna 3 : controle positivo; coluna 4: Tamanduá; coluna 5: ouriço; coluna 6: esquilo; coluna 7: quati; coluna 8: esquilo; coluna 9: controle negativo.

Fonte: Araujo (2012) 


\section{DISCUSSÃO}

A área de construção do condomínio (RSL), onde foi realizada a captura dos animais e a área da soltura da Fazenda Acaraú (FA), onde foi realizada a soltura dos animais capturados na área RSL além de capturas para monitoramento de impacto ambiental, estão localizadas no mesmo município e apresentam as mesmas características de fauna e flora. Entretanto, foi realizada a divisão entra as áreas com o objetivo de verificar uma possível alteração na captura dos animais e na observação de anticorpos neutralizantes para o vírus da raiva em decorrência da situação de "stress" a que os animais provenientes da área RSL foram submetidos.

O maior número de animais capturados observado na Fazenda Acaraú (61,6\% do total de 206 animais capturados) é resultado da suspensão de todas as atividades na área de construção do condomínio (RSL) em maio de 2011. Quando consideramos os 159 animais capturados até o momento da suspensão de coletas na área RSL, o número de animais obtido foi próximo: 82 (51,5\% de 159) provenientes da área FA e 77 (48,5\% de 159) provenientes da área RSL (Figura 25).

As espécies capturadas foram representativas da fauna silvestre da região, não tendo sido observadas espécies animais características de outras regiões do Estado de São Paulo ou do restante do país, situação esperada por se tratar de uma área de Mata Atlântica nativa (Figura 22, Tabela 02).

A variedade de espécies foi semelhante nas áreas RSL e FA. Embora tenham sido observadas algumas variações nessas espécies (Figuras 23 e 24), os animais da espécie Didelphis aurita (gambá) foram predominantes nas duas áreas, seguidos de animais da espécie Cebus apella (macaco-prego). No estudo realizado por Almeida et al. (2001), de pesquisa da AcNs para o vírus da raiva em diversas espécies de mamíferos silvestres provenientes da cidade de São Paulo, os gambás também foram predominantes, seguidos dos primatas.

Todos os animais capturados foram submetidos a coleta de sangue para obtenção de soro para pesquisa de anticorpos contra o vírus da raiva. Foram considerados como reagentes os soros provenientes de

animais onde foi observada a presença de anticorpos neutralizantes para o vírus da raiva, mesmo quando observados títulos abaixo de 0,50Ul/mL (valor considerado como protetor após vacinação em humanos), por serem indicativos de 
um contato prévio com o vírus sem necessariamente indicar proteção contra o mesmo.

A Organização Mundial da Saúde recomenda o valor mínimo de anticorpos neutralizantes de $0,50 \mathrm{Ul} / \mathrm{mL}$ como indicativo de uma resposta vacinal adequada para humanos (WHO, 2011), esse valor também é adotado na avaliação da resposta vacinal em animais domésticos para transporte internacional e para monitorar a vacinação oral de espécies silvestres (OIE, 2009). Entretanto, quando consideramos a presença de anticorpos neutralizantes em outras espécies, em especial mamíferos silvestres, o valor de 0,50UI/mL pode não se aplicar (GASCOYNE et al., 1993; MOORE; HANLON, 2010) e a exclusão de animais com títulos mais baixos pode não ser sempre adequada (HILL; BERAN; CLARK, 1992). Os valores estabelecidos para ponto de corte em animais silvestres devem ser considerados com cautela para as diferentes espécies animais e ser alvo de futuros estudos e discussões.

Os estudos de detecção de anticorpos neutralizantes em mamíferos silvestres descritos na literatura apresentam valores variáveis em relação ao ponto de corte, partindo de 0,06Ul/mL (TURMELLE et al., 2010) para morcegos e 0,09UI/mL para mamíferos terrestres (ROSATTE; GUNSON, 1984). Ainda que a quantificação de anticorpos seja essencial para a avaliação vacinal, nos estudos de circulação viral a detecção destes anticorpos é mais importante que sua titulação, desde que utilizadas técnicas específicas e com ponto de corte que elimine a possibilidade de falsos positivos (MOORE; CHANDRA; BRIGGS, 2007).

A proposta inicial deste estudo foi a detecção de AcNs para o vírus da raiva por meio da técnica de SFIMT. Esta técnica foi escolhida em decorrência de sua ampla utilização no país, inclusive em animais silvestres, com resultados satisfatórios (CHAVES et al., 2006; JORGE et al., 2010; MEGID, 2000; PASSOS; GERMANO; FEDULLO, 2002) e por este motivo a utilização da técnica facilitaria a comparação com os resultados disponíveis na literatura.

Todas as 206 amostras coletadas foram submetidas ao SFIMT, dentre as quais $70(34, \%)$ foram reagentes; isto é, foi detectada a presença de AcNs para o vírus da raiva com títulos a partir de $0,16 \mathrm{Ul} / \mathrm{mL}$ (Tabela 03). No estudo realizado por Almeida em 1998 na cidade de São Paulo e envolvendo espécies semelhantes as do presente estudo, $14 \%$, das amostras foi reagente, sendo considerado o ponto de corte de $0,50 \mathrm{Ul} / \mathrm{mL}$, valor superior ao encontrado em nosso experimento quando considerados os animais com títulos $\geq 0,50 \mathrm{UI} / \mathrm{mL}$ (20 animais - 9,7\% do total de 206). 
Por se tratar de uma área de conservação ambiental, não foi possível realizar a contenção química de todos os animais durante os procedimentos de captura, biometria e coleta de sangue. A contenção física utilizada prejudicou algumas coletas, resultando em pequenas quantidades de amostra, obtenção de soro hemolisado e a impossibilidade de coleta de sangue de alguns animais capturados. A qualidade do soro obtido em algumas amostras levou a consideração da possibilidade de resultados falso positivos em decorrência de reações cruzadas ou inespecíficas de neutralização (BARTON; CAMPBELL, 1988; JENKINS; PERRY; WINKLER, 1988; OIE, 2009). Por este motivo foram ainda realizados o RFFIT ( teste padrão ouro para a detecção de AcNs contra o vírus da raiva recomendado pela WHO e OIE) e o ELISA (para detecção de anticorpos contra o vírus da raiva e não apenas os neutralizantes) nas amostras de soro obtidas.

As amostras consideradas reagente, onde foi observada a presença de anticorpos neutralizantes, no RFFIT representaram 15 amostras, 10,8\% do total de 139 amostras submetidas a este teste. Os resultados do RFFIT foram os considerados para a determinação da evidência de circulação viral entre os animais da área, por se tratar da prova padrão ouro para a detecção de AcNs para o vírus da raiva (Tabela 08).

Os gambás (Didelphis aurita) foram a espécie com maior número de animais capturados $(78,5 \%$ do total de espécies submetidas ao RFFIT) sendo 12 (11\% do total de gambás) animais com soros ragentes (Tabela 08). E também a única espécie onde foi observado título considerado como protetor para a raiva $(=1,00 \mathrm{Ul} / \mathrm{mL})$, em um animal adulto e do sexo feminino, o qual também apresentou título de 1,00UI/mL na SFIMT e positividade no ELISA.

Quando consideramos o SFIMT, gambás foram também predominantes em relação ao número de amostras reagentes; embora com maior porcentagem $(37,1 \%$ do total de 140 amostras submetidas a esta técnica) quando comparados ao RFFIT.

Embora existam estudos demonstrando a alta resistência dos gambás ao vírus da raiva (BEAMER; BARR, 1960), estes animais são susceptíveis a enfermidade, com alta capacidade de adaptação e sinantropismo, sendo frequentemente encontrados em ambientes urbanos ou mesmo rurais e silvestres com elevada circulação de humanos (FOWLER, 1986, MALTA; LUPPI, 2007). Estas características, combinadas com os títulos de anticorpos neutralizantes observados neste estudo e a notificação de um caso de raiva em humanos em decorrência de 
acidente com esta espécie no país em 1990 (BRASIL, 2011) evidenciam a importância do constante estudo e vigilância da raiva nestes animais.

Os macacos-prego foram a segunda espécie em número de animais capturados (16 animais, 11,1\% do total de 139 de amostras submetidas ao RFFIT), sendo que um animal (6,35\% do total de 15 amostras de macaco-prego) apresentou anticorpos neutralizantes, com título de 0,33Ul/mL (Tabela 08) .

Macacos-prego foram predominantes também nos resultados da SFIMT, apresentando 08 animais $(21,6 \%$ do total de macacos-prego) com amostras reagentes (Tabela 04).

Primatas são a terceira ordem animal em transmissão da raiva para humanos, sendo os sagüis da espécie Callithrix jaccus jaccus a principal espécie de primata responsável por esta transmissão (FAVORETTO et al., 2001). Em nosso estudo, apenas macacos-prego foram capturados, situação esperada por se tratar de área de Mata Atlântica nativa e de ocorrência natural desta espécie.

Anticorpos neutralizantes para o vírus da raiva foram observados em animais desta espécie, também sem registros de vacinação, no estudo realizado por Machado et al. em 2012, com macacos-prego provenientes de uma área de conservação na região Sudeste do país. A positividade observada foi de $11,1 \%$, mesmo valor observado no presente estudo quando consideradas todas as espécies.

Macacos-prego foram diagnosticados com raiva (BRASIL, 2011) e sua presença em áreas onde ocorre contato com humanos, somada a sua grande capacidade de adaptação (CATÃO-DIAS, 2006; RYLANDS et al., 2001;), demonstram a importância da vigilância da raiva nesta espécie, assim como em outras espécies de primatas.

Os dois quatis submetidos ao RFFIT apresentaram amostras reagentes (títulos $0,20 U \mathrm{Ul} / \mathrm{mL}$ e $0,12 \mathrm{UI} / \mathrm{mL}$ ). Essas duas amostras reagentes no RFFIT foram também reagentes na SFIMT, representando $50 \%$ do total de 04 amostras de animais desta espécie submetidos a segunda técnica. Animais desta espécie pertencem a ordem Carnivora, família Procyonidae e apresentam hábitos onívoros de alimentação; são considerados curiosos e de fácil socialização com sereshumanos e por vezes mantidos como animais de estimação em tribos indígenas (TEIXEIRA; AMBROSIO, 2007), tendo sigo diagnosticados com raiva no Brasil (FAVORETTO et al., 2002). Adicionalmente, outros animais da família Procyonidae, 
como o guaxinim - Procyon cancrivorous, foram diagnosticados com a enfermidade no país (BRASIL, 2011, FAVORETTO et al., 2006) e o "raccoon" - Procyon lotor - é uma das principais espécies na epidemiologia da raiva na América do Norte (RUPPRECHT; HANLON; KOPROWSKI, 1996; WOLDEHIWET, 2002).

As demais espécies capturadas não apresentaram títulos de AcNs quando submetidas ao RFFIT. Entretanto, todas as espécies estudadas são susceptíveis a enfermidade, e quando consideramos os títulos observados na SFIMT, animais já diagnosticados com a enfermidade como o guaxinim (FAVORETTO et al., 2006) e o cachorro do mato (CARNIELI et al., 2006) apresentaram amostras reagentes. Animais destas duas espécies também apresentaram títulos de anticorpos neutralizantes por meio da técnica de SFIMT em carnívoros silvestres provenientes do Centro-Oeste do Brasil (JORGE et al., 2010).

Amostras provenientes de outras espécies animais, além das já citadas acima, foram reagentes para o SFIMT; como tatu, tamanduá, cutia, caititu e jaguatirica (Tabela 04). Jorge et al. (2010) também relataram a presença de AcNs para o vírus da raiva em uma jaguatirica em seu estudo.

O maior número de animais com amostras reagentes observado na área da Fazenda Acaraú em relação aos provenientes da área da Riviera de São Lourenço não apresentou diferença estatística significante $\left(X^{2}=0,741\right.$ no SFIMT e $X^{2}=0,727$ no RFFIT) e provavelmente é devido ao maior número de capturas realizado na área FA (Tabelas 05 e 09).

A quantidade de machos capturados foi superior a de fêmeas (Figura 26), embora não tenha sido observada uma diferença estatística significante em ambas as técnicas de detecção de AcNs $\left(X^{2}=0,083\right.$ no SFIMT e $X^{2}=1,173$ no RFFIT) (Tabelas 06 e 10).

A predominância de machos foi observada em outros estudos (ALMEIDA et al., 2001; BIGLER et al., 1983; EAST et al., 2001; HILL; BERAN; CLARK, 1992; MACHADO et al.; 2012), porém não foram relatadas evidências de que o gênero influencie a resposta imune ou o contato do animal com o vírus.

O número de animais adultos capturados foi superior a de jovens (Figura 27), e animais adultos também apresentaram predominância em relação as amostras reagentes (dos 15 animais com amostras reagentes para o RFFIT, apenas 02 jovens e 01 com idade indeterminada foram regantes), ainda que a diferença observada 
não tenha sido estatisticamente significante $\left(X^{2}=2,472\right.$ na SFIMT e $p=0,23$ - Teste Exato de Fisher - no RFFIT) (Tabelas 07 e 11).

A diferença observada quando consideramos a idade dos animais não apresentou valor estatisticamente significante, entretanto, o maior número de adultos apresentando AcNs foi observado em outros estudos e é sugestivo de que a resposta imune ao vírus pode ser decorrente de sucessivos contatos em diferentes momentos (ALMEIDA et al., 2001; JENKINS; PERRY; WINKLER, 1988; HILL; BERAN; CLARK, 1992; MACHADO et al., 2012).

A detecção de anticorpos neutralizantes para o vírus da raiva é uma evidência de que este vírus circula entre os animais da área. Esta evidência já foi relatada em outros estudos semelhantes realizados no país em animais de vida livre, sem sintomas da enfermidade e registros de vacinação (ALMEIDA et al., 2001; JORGE et al., 2010; MACHADO et al., 2012 MEGID et al., 2000).

Títulos de ACNs para o vírus da raiva em animais aparentemente saudáveis e sem registro de vacinação já foram observados em diversas espécies de animais silvestres em diferentes países: como "raccoons" nos Estados Unidos (HILL; BERAN; CLARK, 1992); cães selvagens na Tanzânia (GAYSCONE et al., 1993); "Skunks" - cangambás no Canadá (ROSATTE; GUNSON, 1984); Hienas do Serengueti (EAST et al, 2001); raposas nos Estados Unidos (CAREY; McLEAN, 1978; MILLER et al., 2000) e diferentes espécies na Argentina (LORD et al., 1975).

Os títulos observados no presente estudo são sugestivos de um contato dos animais estudados com o vírus da raiva em algum momento. As formas de contato de animais silvestres com o vírus da raiva na natureza são pouco claras; podendo ocorrer pelo contato entre animais da mesma espécie ou de espécies diferentes apresentando excreção viral ou mesmo pela ingestão de pequenos animais contaminados (ALMEIDA et al., 2001; CHARLTON; CASEY, 1979; RAMNSDEN; JOHNSTON, 1975; ROSATTE; GUNSON, 1984).

Nenhum animal capturado apresentou sintomas de raiva; a presença de anticorpos em animais aparentemente saudáveis pode ser decorrente de uma carga de antígenos virais insuficientes para levar a infecção ou infecções abortivas (EAST et al., 2001; HILL; BERAN; CLARK, 1992), e ainda devido a possibilidade de uma determinada variante viral ser menos patogênica e/ou mais imunogênica em determinadas espécies (ROSATTE; GUNSON, 1984) 
Todas as amostras de soro reagentes foram provenientes de espécies de animais (gambás, macacos-prego e quatis) altamente adaptáveis, as quais podem se alimentar de pequenos animais; esse fato pode ser interpretado como uma evidência de que os títulos observados foram decorrentes do contato com o vírus através da ingestão de animais positivos encontrados mortos ou doentes na mata (RAMNSDEN; JOHNSTON, 1975).

Os animais capturados são de vida livre, e até a intervenção para construção do condomínio provavelmente apresentaram pouco ou nenhum contato com humanos, e quase todas as espécies são representativas da fauna local; esses dois fatores praticamente excluem a possibilidade da detecção de anticorpos vacinais, reforçando a hipótese de infecção natural.

O SFIMT, descrito por Favoretto et al. em 1993, é utilizado por mais de 20 anos no Brasil para a detecção de AcNs em seres humanos vacinados com bons resultados (BATISTA et al., 2011; CHAVES et al., 2006). Entretanto, ao compararmos esta técnica com o RFFIT (padrão-ouro para a detecção de ACNs para o vírus da raiva), a sensibilidade observada na técnica pode ser considerada boa $(86 \%)$; porém, a especificidade $(70 \%)$ e a concordância (kappa= 0,68 ) foram mais baixas (Tabela 12).

Essa menor concordância pode ser decorrente das espécies animais presentes neste estudo, onde observamos uma ampla variedade de animais dos quais não existem informações suficientes em relação a susceptibilidade e apresentação da resposta imune ao vírus da raiva. E ainda por se tratar de animais não submetidos a vacinação; não apenas o SFIMT, mas todas as técnicas de detecção de anticorpos contra o vírus da raiva foram validadas em amostras provenientes de seres humanos ou animais submetidos a vacinação.

Uma hipótese adicional para a menor especificidade observada no SFIMT em relação ao RFFIT, é a forma de determinação do ponto de corte utilizado na primeira técnica. No SFIMT, os títulos são definidos a partir da diluição onde se observa uma queda de $50 \%$ no número de células infectadas; em muitas amostras testadas pelo RFFIT foi observada essa queda de $50 \%$ em diluições maiores, porém, a presença de ao menos uma célula infectada em todos os 10 campos observados caracterizou as amostras como não reagentes.

Embora o número de amostras reagentes no RFFIT tenha sido mais baixo em relação ao SFIMT, algumas observações foram comuns aos resultados de ambas as 
técnicas; como o maior número amostras reagentes provenientes de animais adultos, a predominância de gambás e macacos-prego e a presença de soros reagentes (ou títulos $\geq 0,50 \mathrm{UI} / \mathrm{mL}$ no caso da SFIMT) em espécies animais altamente adaptáveis em relação a alimentação e ao habitat (gambás, macacosprego e quatis).

Com o objetivo de comparar a detecção de anticorpos neutralizantes com uma técnica de detecção de anticorpos contra o vírus da raiva, as amostras de soro foram também testadas com um "kit" comercial de ELISA. A técnica de ELISA não depende de cultivo celular para sua realização, diminuindo a possibilidade de citoxicidade em decorrência da qualidade do soro utilizado (CLIQUET et al., 2003; SERVAT et al., 2008). O "kit" comercial utilizado neste estudo foi desenvolvido para o monitoramento da vacinação oral em raposas na Europa, especialmente quando a qualidade das amostras pode estar comprometida em decorrência da contaminação bacteriana ou autólise.

Duas amostras (1,13\% do total de 175 amostras testadas) foram positivas para a prova de ELISA, sendo que uma (proveniente de uma fêmea de gambá adulta) foi positiva também nas técnicas de SFIMT e RFFIT (ambas com título de $1,00 \mathrm{UI} / \mathrm{mL})$.

No estudo realizado por Mork et al. (2011) com raposas do ártico na Noruega não submetidas a vacinação, o vírus da raiva foi detectado nestes animais, entretanto, todas as amostras testadas por meio do ELISA (com um "kit" comercial distinto do utilizado neste estudo) apresentaram resultados negativos.

Vengust et al. no estudo realizado em 2011 em javalis na Eslovênia encontrou $32 \%$ de positividade por meio do ELISA, entretanto, estes animais eram provenientes de uma área com realização de vacinação de populações de raposas.

A baixa concordância observada pode ser decorrente do fato do "kit" utilizado ter sido desenvolvido para raposas vacinadas, e portanto apresentando baixa sensibilidade para as várias espécies deste estudo, especialmente por se tratar de animais não vacinados. A maior parte dos estudos com o ELISA em animais silvestres foi realizada em animais submetidos a vacinação (CLIQUET, 2003; SERVAT, 2006; WASNIEWSKI; CLIQUET, 2011). A resposta vacinal para o vírus da raiva apresenta normalmente maior intensidade (maior produção de anticorpos) do que a resposta a uma infecção natural (MOORE; HANLON, 2010), motivo que poderia explicar a baixa sensibilidade observada no ELISA. 
Adicionalmente, no estudo realizado por Waniewski e Cliquet em 2011, comparando o "kit" comercial utilizado neste estudo com a técnica de FAVN para a detecção de anticorpos em animais domésticos vacinados, a concordância encontrada nos soros com títulos entre $0,5 \mathrm{UI} / \mathrm{mL}$ e $1,00 \mathrm{UI} / \mathrm{mL}$ foi de $50 \%$. Esta baixa concordância em amostras de soro com menores títulos (abaixo de 1,00Ul/mL) foi também observada em outros estudos de comparação de técnicas de detecção de anticorpos contra a raiva em animais silvestres (BARTON; CAMPBELL, 1988; CLIQUET et al., 2003; HILL; BERAN; CLARK, 1992).

A variação nos resultados obtidos em amostras de soro com títulos menores do que $1,00 U \mathrm{I} / \mathrm{mL}$ também foi relatada na comparação entre testes de detecção de anticorpos neutralizantes como entre a RFFIT e a FAVN (BRIGGS et al., 1998). Esta variação, observada em diversos estudos com diferentes técnicas de detecção de anticorpos, pode ser uma das causas da baixa concordância entre os três testes utilizados no presente estudo.

A utilização de mais de uma técnica para a detecção de anticorpos não estava prevista no objetivo inicial do projeto de detectar a evidência de circulação viral na área. A utilização de três técnicas foi decorrente de observações e discussões dos resultados observados ao longo do experimento; portanto, não foi possível realizar um delineamento experimental adequado de forma a permitir uma melhor comparação entre as técnicas.

Os resultados observados com a utilização das técnicas de SFIMT, RFFIT e ELISA nas amostras deste estudo, assim como a ausência de publicações comparando estas técnicas em espécies silvestres no país, levanta a possibilidade da realização de futuros estudos objetivando um melhor entendimento das técnicas de detecção de anticorpos para a raiva nessas espécies. Adicionalmente a realização de estudos objetivando a validação da SFIMT e da ELISA em espécies de animais silvestres e domésticas. Especialmente ao considerarmos a importância das espécies silvestres na epidemiologia da raiva e levando em consideração o fato de que, ao contrário do realizado em muitos países, esses animais não são submetidos a vacinação no Brasil.

As amostras provenientes de animais encontrados mortos também foram representativas da fauna silvestre da região, sem ocorrência de espécies não características da área (Figura 29). 
Embora todas as amostras de sistema nervoso central submetidas as provas de detecção do antígeno viral (IFD, IC e RT-PCR) tenham apresentado resultados negativos, mesmo com a utilização de técnicas que permitiam a detecção viral em amostras em estado de decomposição (Tabela 13); o isolamento do vírus da raiva em morcegos no litoral norte do Estado de São Paulo (FERRAZ; ACHKAR; KOTAIT, 2007), a presença de anticorpos neutralizantes para o vírus da raiva encontrada neste experimento e a pequena disponibilidade de estudos da epidemiologia viral em espécies de mamíferos silvestres na região, assim como em todo o Brasil, confirmam a importância do estudo realizado neste experimento.

Considerando-se os resultados apresentados, não foi possível inferir se o fato de todas as amostras pesquisadas para a presença do vírus terem apresentado resultados negativos é decorrente de uma situação de equilíbrio na circulação do vírus na região ou devido ao fato de animais doentes e/ou mortos em decorrência da enfermidade não terem sido capturados.

A relevância do presente estudo é especialmente justificada ao considerarmos a situação única encontrada; onde os animais foram submetidos a uma situação de "stress" com a derrubada da mata e transposição e adicionalmente submetidos a monitoramento para a detecção de um possível impacto destas atividades, por meio da avaliação destes animais em uma área da soltura e conservação ambiental.

As amostras estudadas são representativas da fauna silvestre local; todas as espécies estudadas podem ser acometidas pelo vírus da raiva e algumas das amostras pertencem a espécies comprovadamente transmissoras da enfermidade para seres humanos e outras espécies animais. Dentre as espécies com casos confirmados de transmissão da raiva para seres humonos podemos citar o morcego hematófago - Desmodus rotundus, gambá - Dipelphis aurita, macaco-prego Cebus apella nigritus, mão pelada - Procyon cancrivorous e cachorro do mato Cerdocyon thous (BRASIL, 2011; CARNIELI et al., 2006; FAVORETTO et al., 2006).

Os animais silvestres apresentam crescente importância na epidemiologia da raiva no Brasil, este fato, somado as crescentes intervenções humanas em áreas de mata nativa, demonstra a necessidade de constantes estudos objetivando o entendimento e o monitoramento da ação destas espécies na circulação e transmissão do vírus da raiva. Futuros estudos epidemiológicos em diferentes regiões do país e diferentes espécies animais poderão fornecer uma informação 
valiosa para a prevenção e controle da enfermidade. Assim como a realização de pesquisas objetivando um melhor entendimento, padronização e validação das diferentes técnicas diagnósticas; levando em especial consideração a grande e única variedade de espécies animais presente em nosso país. 


\section{CONCLUSÕES}

- Foi observada evidência de circulação do vírus da raiva entre os mamíferos silvestres provenientes da área de Mata Atlântica nativa estudada.

- A detecção de anticorpos neutralizantes para o vírus da raiva por meio da técnica de RFFIT é um indicativo da circulação do vírus na região estudada, especialmente entre gambás, macacos-prego e quatis.

- A técnica de SFIMT apresentou boa sensibilidade, porém a especificidade e concordância foram mais baixas em relação a RFFIT para as espécies silvestres provenientes da área estudada.

- A técnica de ELISA utilizada apresentou baixa concordância em relação as técnicas de RFFIT e SFIMT nas espécies silvestres provenientes da área estudada.

- O vírus da raiva não foi detectado nos animais estudados por meio das técnicas de IFD, IC e RT-PCR.

- Futuros estudos utilizando as diferentes técnicas para a detecção de anticorpos contra o vírus da raiva em animais silvestres podem fornecer uma informação valiosa para o melhor estudo da raiva nessas espécies.

- Os testes sorológicos disponíveis necessitam ser reavaliados para a utilização em amostras de diferentes espécies animais não submetidas a vacinação.

- Os resultados obtidos comprovam a importância de constantes estudos de monitoramento e controle da raiva silvestre no Brasil e a necessidade da continuidade de pesquisas dessa natureza. 


\section{REFERÊNCIAS*}

ALBAS, A.; CAMPOS, A. C. A.; ARAUJO, D. B.; RODRIGUES, C. S.; SODRE, M. M.; DURIGON, E. L.; FAVORETTO, S. R. Molecular characterization of rabies virus isolated from non-haematophagous bats in Brazil. Rev. Soc. Bras. Med. Trop. v. 44, n. 6, p. 678683, 2011.

ALMEIDA, M. F. Prevalência de anticorpos anti-rábicos neutralizantes em animais silvestres terrestres do município de São Paulo. 1988 - (Tese de Doutorado) Universidade de São Paulo, São Paulo, 1998.

ALMEIDA, M. F.; MASSAD, E.; AGUIAR, E. A. C.; MARTORELLI, L. F. A.; JOPPERT, A. M. S. Neutralizing antirabies antibodies in urban terrestrial wildlife in Brazil. J. Wil. Dis., v. 37, n. 2, p. 394-398, 2001.

ALMEIDA, M. F.; MARTORELLI, L. F.; AIRES, C. C.; SALLUM, P. C.; DURIGON, E. L.; MASSAD, E. Experimental rabies infection in haematophagus bats Desmodus rotundus. Epidemiol. Infect., v. 133, n. 3, p. 523-527, 2005.

ALMEIDA, M. F.; MARTORELLI, L. F. A.; SODRÉ, M. M.; KATAOKA, A. P. A.; ROSA, A. R.; OLIVEIRA, M. L.; AMATUZZI, E. Rabies diagnosis and serology in bats from the State of São Paulo, Brazil. Rev. Soc. Bras. Med. Trop., v. 44, n. 02, p. 140-145, 2011.

ARAI, Y. T.; YAMADA, K.; KAMEOKA, Y.; HORIMOTO, T.; YAMAMOTO, K.; YABE, S.; NAKAYAMA, M.; TASHIRO, M. Nucleoprotein gene analysis of fixed and street rabies virus variants using RT- PCR. Arch. Virol., v.142, n.9, p.1787-1796, 1997.

ARAUJO, D. B.; LANGONI H.; ALMEIDA, M. F.; MEGID, J. Heminested reverse-trancriptase polymerase chain reaction (hnRT-PCR) as a tool for rabies virus detection in stored an decomposed samples. BMC Res. Notes, v. 1, p. 17, 2008.

ARAUJO, D. B. Estudo epidemiológico do vírus da raiva em mamíferos silvestres provenientes de área de soltura no litoral Norte do Estado de São Paulo, Brasil. 2012 (Tese de Doutorado) - Instituto de Ciências Biomédicas, Universidade de São Paulo, São Paulo, 2012.

ARELLANO-SOTA, C. Vampire bat-transmitted rabies in cattle. Rev. Infect. Dis., v. 10, n. 4, p. 707-709, 1988.

BANERJEE, A. K. Transcription and replication of rhabdoviruses. Microbiol. Rev., v. 51. n. 1, p. $66-87,1987$.

BARTON, L.D.; CAMPBELL, J.B. Measurement of rabies-specific antibodies in carnivores by an enzyme-linked immunosorbent assay. J. Wild. Dis., v.42, n.2, p.246-258, 1988.

BATISTA, H. H. C. R.; LIMA, F. E .S.; MALETICH, D.; SILVA, A. C. R.; VICENTINI, F. K.; ROEHE, L. R.; SPILKI, F. R.; FRANCO, A. C.; ROEHE, P. M. Immunoperoxidase inhibition assay for rabies antibody detection. J. Virol. Methods, v.1 74, p. 65-68, 2011.

\footnotetext{
* ASSOCIAÇÃO BRASILEIRA DE NORMAS TÉCNICAS. NBR 6023: informação e documentação Referências - Elaboração. Rio de Janeiro, 2002. 24p.

BIOSIS. Serial sources for the BIOSIS preview database. Philadelphia, 1996. 468p.
} 
BEAMER, P. D.; MOHR,C. O.; BARR, T. R. Resitance of the opossum to rabies virus. Am. J. Vet. Res., v. 21, p. 507-510, 1960.

BELÁK, S.; BALLAGI-PORDÁNY, A. Application of the polymerase chain reaction (PCR) in veterinary diagnostic virology. Vet. Res. Commun., v. 17, p. 55-72, 1993.

BELLAN, S. E.; CIZAUSKAS, C. A.; MIYEN, J.; EBERSOHN, K.; KUSTERS, M.; PRAGER, K. C.; VAN VUUREN, M.; SABETA, C; GETZ, W. M. Black-backed jackal exposure to rabies virus, canine distemper virus, and Bacillus anthracis in Etosha National Park, Namibia. J. Wild. Dis., v. 48, n. 2, p. 371-381, 2012.

BELOTTO, A.; LEANES, L. F.; SCHNEIDER, M. C.; TAMAYO, H.; CORREA, E. Overview of rabies in the Americas. Virus Res., v. 111, p. 5-12, 2005.

BIGLER, W. J.; HOFF, G. L.; SMITH, J. S.; MCLEAN, R. G.; TREVINO, I. J. Persistence of rabies antibody in free-ranging racoons. J. Infec. Dis., v. 148, n. 3, p. 610, 1983.

BLACK, E. M.; McELHINNEY, L. M.; LOWINGS, P. L.; SMITH, J.; JOHNSTONE, P.; HEATON, P. R. Molecular methods to distinguish between classical rabies and the rabiesrelated European bat Lyssaviruses. J. Virol. Methods, v. 87, p. 123-131, 2000.

BLANCOU, J.; MESLIN, F. X. Modified live-virus rabies vaccines for oral immunization of carnivores. In: MESLIN, F. X.; KAPLAN, M. M.; KOPROWSKI, H. Laboratory techniques in rabies, 4. Ed. Genebra, WHO, 1996, p. 324-331.

BOURHY, H.; KISSI, B.; TORDO, N. Molecular diversity of the Lyssavirus genus. Virology, V. 194, p. 70-81, 1993.

BRASIL, Ministério da Saúde. Raiva humana transmitida por morcegos no Estado do Pará e Maranhão. 25 de outubro, 2005. Disponível em:

<http://portal.saude.gov.br/portal/arquivos/pdf/nota_raiva.pdf.> Acesso em: 17 Ago 2010.

BRASIL, Ministério da Saúde, Programa de controle, vigilância e profilaxia da raiva, Disponível em:

<http://portal.saude.gov.br/portal/arquivos/pdf/programa vigilancia raiva dados parciais 11 .pdf >. Acesso em :11 Mar 2012.

BRASIL, Ministério da Saúde, Portal da Saúde, Raiva: Informações gerais sobre a doença, disponível em:

< http://portal.saude.gov.br/portal/saude/profissional/visualizar texto.cfm?idtxt=32020 >

Acesso em: 13 Maio 2012b.

BRIGGS, D. J.; SMITH, J. S.; MUELLER, F. L.; SCHWENKE, J.; DAVIS, R. D.; GORDON, C. R.; SCHWEITZER, K.; ORCIARI, L A.; YAGER, P. A.; RUPPRECHT, C. E. A comparison of two serological methods for detecting the immune response after rabies vaccination in dogs and cats being exported to rabies-free areas. Biologicals, v. 26, p. 347-355, 1998.

CABRAL, C. C.; MORAIS, A. C. N.; DIAS, A. B. A. B.; ARAUJO, M. G.; MOREIRA, W. C.; MATTOS, G. L. M. Circulation of the rabies virus in non-hematophagous bats in the City of Rio de Janeiro, Brazil, during 2001 - 2010. Rev. Soc. Bras. Med. Trop., v. 45, n. 2, p. 180183, 2012.

CAMPOS, A. C. A. Estudo genético da variante do vírus da raiva mantida por populações dp morcego hematófago Desmodus rotundus. 2011, (Tese de Doutorado) Instituto de Ciências Biomédicas, Universidade de São Paulo, São Paulo, 2011. 
CARNIELI, P. J.; BRANDÃO, P. E.; CARRIERI, M. L.; CASTILHO, J. G.; MACEDO, C. I.; MACHADO, C. I.; MACHADO, L. M.; RANGEL, N.; DE CARVALHO, V. A.; MONTEBELLO, L.; KOTAIT, I. Molecular epidemiology of rabies virus strains isolated from wild canids in Northeastern Brazil. Virus Res., v. 120, p. 113-120, 2006.

CAREY, A. B.; MC LEAN, R. G. Rabies antibody prevalence and virus tissue tropism im wild carnivores in Virginia. J. Wild. Dis. v. 14, p. $487-491,1975$.

CASTILHO, J. G.; CARNIELI, P.; OLIVEIRA, R. N.; RAHL, W. O.; CAVALCANTE, R.; SANTANA, A. A.; ROSA, W. L. G. A.; CARRIERI, M. L.; KOTAIT, I. A Comparative study of rabies virus isolates from hematophagous bats in Brazil, J. Wild. Dis., v. 46, n. 4, p. 13351339, 2010.

CATÃO-DIAS, J. L. Primatas do novo mundo. Em: CUBAS, Z. S.; SILVA, J. C. R.; CATÃODIAS, J. L. Tratado de animais selvagens (medicina veterinária), São Paulo: Rocca Brasil, 2006, p.358-377.

CELIS, E.; WIKTOR, T.; DIETZSCHOLD, B; KOPROWSKI, H. Amplification of rabies virusinduced simulation of human t-cell lines and clones by antigen-specific antibody. J. Virol. , v.56, p.436-433, 1985.

CHARLTON, K. M.; CASEY, G. A. Experimental oral and nasal transmisson of rabies virus in mice. Can. J. Comp. Med., v. 43, n. 1, p. 10-15, 1979.

CHAVES, L. B.; MAZUTTI, A. L. C.; G. M. M. CAPOLARE; SCHEFFER, K. C.; SILVA, A. C. R. Rabies virus neutralizing antibodies: comparison ot two evaluation test in cell culture. IN: Anais da XVII Reunião Internacional de Raiva nas Américas - RITA XVII, p. 161, 2006.

CLIQUET, F.; AUBERT, M.; SAGNÉ, L. Development of a fluorescent antibody virus neutralisation test (FAVN test) for tem quantitation of rabies-neutralising antibody. J. Immun. Methods, v. 212, p. 79-87, 1998.

CLIQUET, F.; MULLER, T.; MUTINELLI, F.; GERONUTTI, S.; BROCHIER, B.; SELHORST, T.; SCHEREFFER, J.; KRAFFT, N.; BUROW, J.; SCHAMEITAT, A.; SCHLUTER, H.; AUBERT, M. Standardisation and establishment of a rabies ELISA test in European laboratories for assessing the efficacy of oral fox vaccination campaigns. Vaccine, v. 21, p. 2986 - 2993, 2003.

CLIQUET, F.; McELHINNEY, L. M.; SERVAT, A.; BOUCHER, J. M.; LOWINGS, J. P.; GODDARD, T.; MANSFIELD, K. L.; FOOKS, A. R. Development of a qualitative indirect ELISA for the measurement of rabies virus-specific antibodies from vaccinated dogs and cats. J. Virol. Meth., v. 117, p.1-8, 2004.

COX, J. H. I.; DIETZSCHOLD, B.; SCHNEIDER, L. G. Rabies virus glycoprotein: Biological and serological characterization. Infect. Immunol., v. 16, p. 485-499, 1977.

CUNHA, M. S. C.; LARA, M. C. C. S. H.; NASSAR, A. F. C.; ALBAS, A.; SODRÉ, M. M.; PEDRO, W. A. Bat rabies in the north-northwestern regions of the State of São Paulo, Brazil: 1997-2002. Rev. Saúde Pública, v. 40, n. 6, p. 1082-1086, 2006.

DEAN, D. J.; ABELSETH. M. K.; ATANASIU, P. The fluorescent antibody test. In: MESLIN, F. X.; KAPLAN, M. M.; KOPROWSKI, H. Laboratory techniques in rabies, $4^{\text {th }}$ ed., Genebra, WHO, 1996, p. 99-95. 
DE MATTOS, C. C.; DE MATTOS, C. A.; LOZA-RUBIO, E.; AGUILAR-SETIEM, A.; ORCIARI, L. A.; SMITH, J. S. Molecular characterization of rabies virus isolates from México: implications for transmission dynamics and human risk. Am. J. Trop. Med. Hyg., v. 61, n. 4, p. 587-597, 1999.

DEEM, L. S.; DAVIS, R.; PACHECO, L. F. Serologic evidence of nonfatal rabies exposure in a free-ranging oncilla (Leopardus tigrinus) in Cotapata National Park, Bolivia. J. Wild. Dis., v. 40, n. 4, p. 811-815, 2004.

DIETZSCHOLD, B.; KOPROWSKI, H. Rabies transmission from organ transplant in the USA. Lancet, v. 364, p.649-649, 2004.

DREESEN, D. W. Animal vaccines. In: JACKSON, A. C.; WUNNER, W .H. Rabies, $2^{\mathrm{a}}$ Ed., Londres, Elsevier, 2007, p.517-530.

EAST, M. L.; HOFER, H.; COX, J. H.; WULLE, U.; WIIK, H.; PITRA, C. Regular exposure to rabies virus and lack of symptomatic disease in Serengeti spotted hyenas. Proc. Nat. Acad. Sci, USA, v. 98, n. 26, p. 15026-15031, 2001.

FAVI, M.; DE MATTOS, C. C.; YUNG, V.; CHALA, E.; LOPEZ, L. R.; DE MATTOS, C. C. First case of human rabies in Chile caused by an insectivorous bat virus variant. Emerg. Infect. Dis., v. 8, n. 1, p. 79-81, 2002.

FAVORETTO, S. R.; CARRIERI, M. L.; TINO, M. S.; ZANETTI, C. R.; PEREIRA, O. A. Simplified fluorescent inhibition microtest for the titration of rabies neutralizing antibodies. Rev. Inst. Med. Trop. Sao Paulo, v. 35, n. 2, p. 171-175, 1993.

FAVORETTO, S. R.; DEMATTOS, C. C.; MORAIS, N. B.; ARAUJO, A. A.; DEMATTOS, C. A. Rabies in Marmosets (Callithrix jachus), Ceará, Brazil. Emerg. Infect. Dis., v. 7; n. 6; p., 2001.

FAVORETTO, S. R.; CARRIERI, M. L.; CUNHA, E. M.; AGUIAR, E. A.; SILVA, L. H.; SODRÉ, M. M.; SOUZA, M. C.; KOTAIT, I. Antigenic typing of Brazilian rebies virus samples isolated from animals and humans, 1989-2000. Rev. Inst. Med. Trop. São Paulo, v. 44, n. 3, p. 91-95, 2002.

FAVORETTO, S. R.; MARTORELLI, L. F.; ELKHOURY, M. R.; ZARGO, A. M.; DURIGON, E. $L$. Rabies virus detection and phylogenetic studies in samples from an exhumed human. Clin. Infect. Dis., v. 41, n. 3, p. 413-414, 2005.

FAVORETTO, S. R.; DE MATTOS, C. C.; MORAIS, N. B.; CARRIERI, M. L.; ROLIM, B. N.; SILVA, L. M.; RUPRPECHT, C. E.; DURIGON, E. L.; DE MATTOS, C. A. Rabies virus maintened by dogs in humans and terrestrial wildlife in Ceará state, Brazil. Emerg. Infect. Dis., v.12, n. 12, p. 1978-1981, 2006.

FEHLNER-GARDINER, C.; RUDD, R.; DONOVAN, D.; SLATE, D.; KEMPF, L.; BADCOCK, J. Comparing Onrab $\AA$ and Raboral V-RG $®$ oral rabies vaccine field performance in racoons and striped skunks, New Brunswick, Canada and Maine, USA. J. Wild. Dis., v. 48, n. 1, p. 157-167, 2012.

FERRAZ, C.; ACHKAR, S. M.; KOTAIT, I. First report of rabies in vampires bats (Desmodus rotundus) in an urban area, Ubatuba, São Paulo State, Brazil. Rev. Inst. Med. Trop. São Paulo, v. 49, n. 6, p. 389-390, 2007. 
FEYSSAGUET, M.; DACHEUX, L.; AUDRY, L.; COMPOINT, A.; MORIZE, J. L.; BLANCHARD, I.; BOURHY, H. Multicenter comparative study of a new ELISA, Platelia ${ }^{\text {TM }}$ Rabies II, for the detection and titration of anti-rabies glycoprotein antibodies and comparison with the rapid fluorescent inhibition test (RFFIT) on human samples from vaccinated and nom-vaccinated people. Vaccine, v. 25, p. 2244-2251, 2007.

FORTHOFER, R. N.; LEE, E. S.; HERNANDEZ, M. Analysis of categorical data In: Biostatistics: a guide to design, analysis and discovery, 2: ed. London: Elsevier, 2007, p.269-296.

FOWLER, M. E. Order Marsupialia (Opossums). In: FOWLER, M. E.; PEDERSEN, D. Zoo and Wild Animal Medicin, W.B. Sauder Company, 1986.

GAIA Consultoria e Gestão Ambiental, São Paulo, S.P., 2011.

GAUDIN, Y.; TUFFEREAU, C.; SEGRETAIN, D.; KNOSSOW, M.; FLAMAND, A. Reversible conformational changes and fusion activity of rabies virus glycoprotein. J. Virol., v. 65, n. 9, p 4853-4846, 1991.

GAYSCONE, S. C.; LAURENSON, M. K.; LELO, S.; BORNER, M. Rabies in African wild dogs (Lycaon pictus) in the Serengeti region, Tanzania. J. Wild. Dis. v. 29, n. 3, p. 396-402, 1993.

GLUCK, R. Purified duck-embryo vaccine for humans. In: MESLIN, F. X.; KAPLAN, M. M.; KOPROWSKI, H. Laboratory techniques in rabies, 4 ed., Geneva, WHO, 1996, p.253-258.

GOOGLE: Mapa da cidade de Bertioga, São Paulo. EUA: Dados Catalográficos, Mapalinc, 2012. Disponível em < http://www.mapas.guiamais.com.br/guia/bertioga-sp > Acesso em: 14 Jun 2012.

HEINEMANN, M. B.; FERNADES-MATIOLI, F. M.; CORTEZ, A.; SOARES, R. M.; SAKAMOTO, S. M.; BERNARDI, F.; ITO, F. H.; MADEIRA, A. M.; RICHTZENHAIN, L. J. Genealogical analysis of rabies virus strains from Brazil based on $\mathrm{N}$ gene alleles. Epidemiol. Infect., v. 128, n. 3, p. 503-511, 2002.

HILL, R. E.; BERAN.; G. W.; CLARK, W. R. Demonstration of rabies virus-specific antibody in the sera of free-ranging lowa raccoons (Procyon lotor). J. Wild. Dis., v. 28, n.3, p. 377385, 1992.

IAMAMOTO, K.; QUADROS, J.; QUEIROZ, L. H. Use of aspiration method for collecting brain samples for rabies diagnosis in small wild animals. Zoon. Public. Health., v. 58, n. 1, p. 28-31, 2011.

INTERNATIONAL COMITTEE ON TAXONOMY OF VIRUSES. Disponível em: $\mathrm{http} / / / \mathrm{www}$.ictvonline.org/virusTaxonomy.asp?version=2009. Acesso em 17 de janeiro de 2012.

INSTITUTO PASTEUR. Programa Estadual de controle da raiva: Número de animais positivos para raiva por mês, município e espécie animal no Estado de São Paulo - Ano 2011. Disponível em:

$<$ http://www.pasteur.saude.sp.gov.br/informacoes/Amostras Positivas para Raiva Animal SP2011.pdf.>. Acesso em: 20 Maio 2012.

JACKSON, A. C. Pathogenesis. In: JACKSON, A. C.; WUNNER, W. H. Rabies, 2: ed, Londres: Elsevier, 2007, p. 341.382. 
JENKINS, S. R.; PERRY, B. D.; WINKLER, W. G. Ecology and epidemiology of racoon rabies. Rev. Infect. Dis., v. 14, n. 4, p. 620-625, 1988.

JOHNSON, N.; PHILLPOTTS, R.; FOOKS, A. R. Airborne transmission of lyssaviruses. J. Med. Microbiol., v. 55. p. $785-790,2006$.

JOHNSON, N.; CUNNINGHAM, A. F.; FOOKS, A. R. The immune response to rabies virus infection and vaccination Vaccine, v. 28, p. 3896-3901, 2010.

JORGE, R .S. P.; PEREIRA, M. S.; MORATO, R. G.; SCHEFFER, K. C.; CARNIELI, P.; FERREIRA, F.; FURTADO, M. M.; KASHIVAKURA, C. K.; SILVEIRA, L.; JACOMO, A. T. A.; LIMA, E. S.; PAULA, R. C.; MAY-JUNIOR, J. A. Detection of rabies virus antibodies in brazilian free-ranging wild carnivores. J. Wild. Dis., v. 46. n. 4, 2010.

KISSI, B.; TORDO, N.; BOURHY, H. Genetic polymorphism in the rabies virus nucleoprotein gene. Virology, v. 209, n. 2, p. 526-537, 1995.

KOPROWSKI, H. Visit to an ancient curse. Sci. Am. Sci. Med., v. 2, p. 48-55, 1995.

KOPROWSKI, H. The mouse inoculation test In: MESLIN, F. X.; KAPLAN, M. M.; KOPROWSKI, H. Laboratory techniques in rabies, 4. ed. Genebra: WHO, 1996, p.80-86.

KUZMIN, I. V.; MAYER, A. E.; NIEZGOA, M.; MARKOTTER, W.; AGWANDA, B.; BREIMAN, R.F.; RUPPRECHT, C. E. Shimoni bat virus, a new representative of the Lyssavirus genus. Virus Res. v. 6., p.197-210, 2010.

LAFON, M. Immunology. In: JACKSON, A. C.; WUNNER, W. H. Rabies, 2 ed. Londres: Elsevier ,2007, p. $489-505$.

LANGONI, H.; LIMA, K.; MENOZZI, B. D.; SILVA, R .C. Rabies in the big fruit eating bat Artibeus lituratus from Botucatu, southeastern Brazil. J. Venom. Anim. Toxins incl. Trop. Dis., v. 11, n. 1, p. 84-87, 2005.

LAZARINI, S. R. F. Estudo antigênico e genético de amostras de vírus da raiva isolado de humanos no Brasil - 1997-2003. Tese (Doutorado) - Instituto de Ciências Biomédicas, Universidade de São Paulo, São Paulo, 2006.

LORD, R .D.; DELPIETRO, H.; FUENZALIDA, E.; DIAZ, A. M. O.; LAZARO, L. Presence of rabies neutralizing antibodies in wild carnivores following an outbreak of bovine rabies. $\mathbf{J}$. Wild. Dis., v. 11, p. 210-213, 1975.

MACHADO, G. P.; PAULA ANTUNES, J. M.; UIEDA, W.; BIONDO, A. W.; ANDRADE, CRUVINEL, T. M.; KATAOKA, A. P.; MARTORELLI, L. F.; JORGE, D.; AMARAL, J. M.; HOPPE, E .G.; NETO, G. G.; MEGID, J. Exposure to rabies virus in a population of freeranging capuchin monkey (Cebus apella nigritus) in a fragmented, environmentally protected area in Southeastern Brazil. Primates, (Epub ahead of print), 2012.

MALTA, M. C. M.; LUPPI, M. M. Marsupialia - Didelphimorphia (Gambá - Cuíca). In: CUBAS, Z.S. Tratado de Medicina de Animais Selvagens, 2. Ed. , São Paulo, 2007, p. $340-357$.

MEGID, J. Occurrence of rabies neutralizing antibodies in wild deer (Blastocerus dichotomus) from the western region São Paulo Estate, Brasil. The International J. Vet. Med., 2000, Disponível em< http://www.priory.com/vet/deer.htm >. Acesso em: $21 \mathrm{Mar}$ 2012. 
MESLIN, F. X.; KAPLAN, M .M. General considerations in the production and use of braintissue and purified chiken-embryo vacicnes for human use. In: MESLIN, F. X.; KAPLAN, M. M.; KOPROWSKI, H. Laboratory techniques in rabies, 4. ed. Genebra: WHO, 1996, p. 221-228.

MILLER, D. S.; COVELL, D. F.; MCLEAN, R. G.; ADRIAN, W. J.; NIEZGODA, M.; GUSTAFSON, J. M.; RONGSTAD, O. J.; SCHULTZ, R. D.; KIRK, L. J.; QUAN, T. J. Serologic survey for selected infectious diseases in swift and kit foxes from the western United States. J. Wild. Dis., v. 36, n. 4, p. 798-805, 2000.

MOORE, S. M.; HANLON, C. A. Rabies-specific antibodies: measuring surrogates of protection against a fatal disease. Plos Negl. Trop. Dis. , v. 4, n. 3, p. 1-6, 2010.

MOORE, S. M.; CHANDRA, R. G.; BRIGGS, D. J. Rabies Serology In: JACKSON, A. C.; WUNNER, W. H. Rabies, $2^{a}$ Ed. Londres, Elsevier, 2007, p.471-488.

MORK, T.; BOHLIN, J.; FUGLEI, E.; ASBAKK, K.; TRYLAND, M. Rabies in the arctic fox population, Svalbard, Norway. J. Wild. Dis., v. 47, n. 4, p. 945-957, 2011.

NEUBERT, A.; SCHUSTER, P.; VOS, A.; POMMERENING, E. Immmunogenicity and efficacy of the oral rabies vaccine SAD B19 in foxes. J. Vet. Med., v. 48, p. 179-183, 2001.

NICHOLSON, K. G. Cell-culture vaccines for human use: general considerations. In: MESLIN, F. X.; KAPLAN, M. M.; KOPROWSKI, H. Laboratory techniques in rabies, 4 ed. Genebra: WHO, 1996.

NOORDHUIZEN, J. P.; FRARKENA, K.; VAN DER HOOFD.; GRAAT, E. A. M. Application of quantitative methods in veterinary epidemiology. Wageningen, 1997.

ORGANISATION MONDIALE DE LA SANTE ANIMALE. Rabies. In: Manual of Diagnostic Tests and Vaccines for Terrestrial Animals 2009. Cap. 2. 1. 13, p. 304-323. Disponível em:

http://www.oie.int/fileadmin/Home/eng/Health standards/tahm/2008/pdf/2.01.13 RABIES.pdf . Acesso em: 15 Abr 2012.

OLIVEIRA, R. N.; SOUZA, S. P.; LOBO, R. S.; CASTILHO. J. G.; MACEDO, C. I.; CARNIELI, P. J.; FAHL, W. O.; ACHKAR, S. M.; SCHEFFER, K. C.; KOTAIT, I.; CARRIERI, M. L.; BRANDÃO, P. E. Rabies virus in insectivorous bats: implications of the diversity of the nucleoprotein and glycoprotein genes for molecular epidemiology. Viroloy, v. 405, n. 2, p. 352-360, 2010.

PASSOS, E. C.; GERMANO, P. M. L.; FEDULLO, J. D. L.; Resposta immune humoral em macacos-prego (Cebus apella) mantidos em cativeiro, após a revacinação com vacina antirábica Fuenzalida e Palácios modificada de uso veterinário. Bras. J. Vet. Res. Anim. Sci. , v. 39, p. 181-188, 2002.

PHILIPPA, J.; CHAMBRILLON-FOURNIER, C.; FOURNIER, P.; SCHAEFTENAAR, W.; VAN DE BILT, M.; HERWEIJNEN, R.; KUIKEN, M.; DITHARRY, S.; JOUBERT, L.; OSTERHAUS, A. Serologic survey for selected viral pathogens in free-ranging European mink (Mustela lutreola) and other mustelids from south-western France. J. Wild. Dis. v. 44, n. 4, p. 791801, 2008.

PRINGLE, C. R. The order mononegavirales. Arch. Virol., v.117, p.137-140, 1991. 
QUEIROZ, L. H.; FAVORETTO, S. R.; CUNHA, E. M. S.; CAMPOS, A. C. A.; LOPES, M. C.; CARVALHO, C.; IAMAMOTO, K.; ARAUJO, D. B.; VRNDITTI, L. L.; RIBEIRO, E. S.; PEDRO, A. W.; DURIGON, E. L. Rabies in southeast Brazil: a change in the epidemiological pattern. Arch. Virol., v. 157, p. 93-105, 2012.

RAMOS, P. M.; RAMOS, P. S. Acidentes humanos com macacos em relação a tratamentos profiláticos para a raiva, no Município de São Paulo, Brasil. Rev. Bras. Med. Trop., v. 35, n. 6, p. 575-577, 2002.

RAMSDEN, R. O.; JOHNSTON, D. H. Studies of the oral infectivity of rabies virus in Carnivora. J. Wild. Dis. v. 11, p. 312-324, 1975.

ROMJIM, P. C.; VAN DER HEIDE, R.; CATTANEO, C. A. M. Study of Lyssaviruses of bat origin as a source of rabies for other animal species in the state of Rio de Janeiro, Brazil. Am. J. Trop. Med. Hyg., v. 69, n. 1, p. 81-86, 2003.

ROSA, E. S. T.; KOTAIT, I.; BARBOSA, T. F. S. Bat-transmitted human rabies outbreaks, Brazilian Amazon. Emerg. Infect. Diseases, v. 12, n. 8, p. 1197-1202, 2006.

ROSATTE, R. C.; GUNSON, J. R. Presence of neutralizing antibodies to rabies virus in striped skunks from areas free of skunk in Alberta. J. Wild. Dis. v. 20, n. 03, p. 171-176, 1984.

RUDD, R. J.; TRIMARCHI, C. V. Development and evaluation of an in vitro virus isolation procedure as a replacement for the mouse inoculation test in rabies diagnosis. J. Clin. Microbiol., v. 27, n. 11, p. 2522-2528, 1989.

RUPPRECHT, C. E.; HANLON, C. A.; KOPROWSKI, H. General considerations in the use of recombinant rabies vaccines for oral immunization of wildlife. In: MESLIN, F. X.; KAPLAN, M. M.; KOPROWSKI, H. Laboratory techniques in rabies, 4 ed., Geneva, WHO, 1996, p.341 346.

RUPPRECHT, C. E.; HANLON, C. A.; HEMACHUDHA, T. Rabies re-examined. Lancet Infect. Dis., v. 2, p. 327-343, 2002.

RYLANDS, A. B.; VALLADARES-PÁDUA, C.; SILVA, R. R.; BOERE, V.; CATÃO-DIAS, J. L.; PISSINATI, A.; GUIMARÃES, M. A. B. V. Order Primates (Primates). In: FOWLER, M. E.; CUBAS, Z. S. Biology, medicine and surgery of south-american wild animals, EUA: Isupress, 2001, p. 256-258.

SALAS-ROJAS, M.; SÁNCHEZ-HÉRNANDEZ, C.; ROMERO-ALMARAZ, M. L.; SCHNELL, G. D.; SCHMID, R. K.; AGUILAR-SETIÉN, A. Prevalence of rabies and LPM paramyxovirus antibody in non-hematophagus bats captured in the Central Pacific coast of Mexico. Trans. R. S. Trop. Med. Hyg., v. 98, p. 577-584, 2004.

SCHAEFER, R.; CALDAS, E.; SCHMIDT, E.; KING, A. A.; ROCHE, P. M. First case of cat rabies in southern Brazil for 11 years. Vet. Rec., v. 16, p. 216, 2002.

SCHNEIDER, M. C.; BELOTTO, A.; ADÉ, M. P.; HENDRICKX, S.; LEANES, M. J.; MEDINA, G.; CORREA, E. Current status of human rabies transmitted by dogs in Latin America. Cad. Saúde Pública, v. 23, n. 9, p. 2049-2063, 2007.

SERVAT, A.; LABADIE, A.; HAMEN, A.; HOUE, F.; CLIQUET, F. Inter-laboratorial trial to evaluate the reproductibility of a new ELISA to detect rabies antibodies in vaccinated domestic and wild carnivores. Biologicals, v. 36, p. 19-26, 2008. 
SHANKAR, V.; O'SHEA, T. J.; RUPPRECHT, C. E.; BOWEN, R. A. Rabies seroprevalence in a commensal population of big brown bats in Colorado. In: XII International Meeting on Research Advances and Rabies Control in the Americas, Anais, p. 64, Ciudad de Oaxaca, Mexico, 2002.

SILVA, M. V.; XAVIER, S. M.; MOREIRA, W. C.; SANTOS, B. C.; ESBÉRARD, C. E. Rabies virus in Nyctinomops laticaudatus bats in the City of Rio de Janeiro: isolation, titration and epidemiology. Rev. Soc. Bras. Med. Trop., v. 40, n. 4, p. 479-481, 2007.

SLATE, D.; ALGEO, T. P.; NELSON, K. M.; CHIPMAN, R. B.; DONOVAN, D.; BLANTON, J. D.; NIEZGODA, M.; RUPPRECHT, C. E. Oral rabies vaccination in North America: opportunities, complexities and challenges. Plos Negl. Dis., v. 3, n. 12, p. 1-9, 2009.

SMITH, J. Mouse model for abortive rabies infection of the central nervous system. Infect. Immunol.. v. 31, p. 297-308, 1981.

SMITH, J. S.; ORCIARI, L. A.; YAGER, P. A.; SEIDEL, H. D.; WARNER, C. K. Epidemiologic and historical relationships among 87 rabies virus isolates as determined by limited sequence analysis. J. Infec. Dis., v. 166, n. 2, p. 296-307, 1992.

SMITH, J. S. New aspects of rabies with emphasis on epidemiology, diagnosis and prevention of the disease in the United States. Clin. Microbiol. Rev., v. 9, n. 2, p. 166-176, 1996.

SMITH, J. S.; YAGER, P. A.; BAER, G. M. A rapid fluorescent focus inhibition test (RFFIT) for determining rabies virus-neutralizing. Em: MESLIN, F. X.; KAPLAN, M. M.; KOPROWSKI, H. Laboratory techniques in rabies. 4 ed., Genebra: WHO, 1996, p.181-192.

SODRÉ, M. M.; GAMA, A. R.; ALMEIDA, M. F. Updated list of bats species positive for rabies in Brazil. Rev. Inst. Med. Trop. São Paulo, v. 52, n. 2, p. 75-81, 2010.

SOS Mata Atlântica. Mata Atlântica Disponível em:

$<$ http://www.sosmatatlantica.org.br/index.php?section=info\&action=mata>. Acesso: 03 Maio 2012.

TEIXEIRA, R. H. F.; AMBROSIO, S. R. Carnivora - Procyonidae (Quati, Mão-pelada e Jupará). In: CUBAS, Z. S.; SILVA, J. C. R.; CATÃO-DIAS, J. L.: Tratado de Animais selvagens - medicina veterinátria 2: ed. São Paulo: Rocca, 2007, p.571-583.

THRUSFIELD, M. Veterinary epidemiology. 2: ed. London: Butterworth, 1986, 280p.

TORDO, N.; POCH, C.; ERMINE, A.; KEITH, G. Primary structure of leader RNA and nucleoprotein genes of the rabies genome: Segmented homology with VSV. Nucleic Acids Res.,v. 14, p .2671-2683, 1986a.

TORDO, N.; POCH, O.; ERMINE, A.; KEITH, G.; ROUGEON, F. Walking along the rabies genome: is the large G-L intergenic region a remnant gene? Proc. Natl. Acad. Sci. USA, v. 83, n.11, p. 3914-3918, 1986b.

TORDO, N.; POCH, O.; Structure of rabies virus. In: CAMPBELL, J.B.; CHARLTON, K.M., Rabies, Boston: Kluwer Academic Publishers, 1988, p. 25-45.

TRIMARCHI, C. V.; NADIN-DAVIS, S. A. Diagnostic evaluation. In: JACKSON, A. C.; WUNNER, W. H. Rabies, 2" ed., Londres: Elsevier, 2007, p.411-469. 
TURMELLE, A. S.; ALLEN, L. C.; SCHMIDT-FRENCH, B. A.; JACKSON, F. R.; KUNZ, T. H.; MCCRACKEN, G. F.; RUPPRECHT, C. E. Response to vaccination with a commercial inactivated rabies vaccine in a captive colony of brazilian free-tailed bats (Tadarida brasiliensis). J. Wild. Dis., v. 41, n. 1, p. 140-143, 2010.

VENGUST, G.; HOSTNIK, P.; CEROVSEK, M.; CILENSEK, P.; MALOVRH, T. Presence of antibodies against rabies in wild boars. Acta Vet. Hung.,v. 59, n. 1, p. 149-154, 2011.

WARNER, C. K.; ZAKI, S. R.; SHIEH, W.; WHITFIELD, S. G.; SMITH, J. S.; ORCIARI, L. A.; SHADDOCK, J. H.; NIEZGODA, M.; WRIGHT, C. W.; GOLDSMITH, C. S.; SANDERLIN, D. W.; YAGER, P. A.; RUPPRECHT, C. G. Laboratory investigation of human deaths from vampire bat rabies in Peru. Am. J. Trop. Med. Hyg., v. 60, n. 3, p. 502-507, 1999.

WARREL, M. J. Human deaths from cryptic bats in the USA. Lancet, v. 364, p. 65-66, 1995.

WASNIESKI, M.; CLIQUET, F. Evaluation of ELISA for detection of rabies antibodies in domestic carnivores. J. Virol. Met. , v.179, n. 1, p. 166-175, 2011.

WEBSTER, L. T.; DAWSON, J.R. Early diagnosis of rabies by mouse inoculation. Measurement of humoral immunity to rabies by mouse protection test. Proc. Soc. Exp. Biol. Med., v. 32, p. 570-573, 1935.

WORLD HEALTH ORGANIZATION Expert Commitee on Rabies. Rabies: Fact Sheet N99. Geneva: WHO, 2011. Disponível em: <http://www.who.int/mediacentre/factsheets/fs099/en>. Acesso em: 09 Fev 2012.

WOLDEHIWET, Z. Rabies: recent developments. Res. Vet. Sci., v. 73, p. 17-25, 2002.

WUNNER, W. H.; REAGAN, K. J.; KOPROWSKI, H. Characterization of saturable biding sites for rabies virus. J. Virol., n. 50, p. 691-697, 1984.

WUNNER, W.H. Rabies Virus In: JACKSON, A. C.; WUNNER, W.H. Rabies, 2. ed. Londres: Elsevier, 2007, p. 23-69.

ZALAN, E.; WILSON, C.; PUKITIS, D.A. A microtest for the quantification of rabies nutralizing antibodies. J. Biol. Standardization, v. 7, p. 213-220, 1979. 


\section{ANEXOS}

\section{A}

Ministério do Meio Ambiente - MMA

Instituto Brasileiro do Meio Ambiente e dos Recursos Naturais Renováveis - IBAMA

Instituto Chico Mendes de Conservação da Biodiversidade - ICMBio

Sistema de Autorização e Informação em Biodiversidade - SISBIO

\section{Autorização para atividades com finalidade científica}

\begin{tabular}{|c|c|c|}
\hline Número: 15486-2 & Data da Emissão: 22/06/2009 13:26 & Data de Validade: $22 / 06 / 2010$ \\
\hline \multicolumn{3}{|l|}{ Dados do titular } \\
\hline Registro no Ibama: 2090224 & Nome: Silvana Regina Favoretto Lazarini & CPF: 045.706.968-64 \\
\hline \multicolumn{3}{|c|}{$\begin{array}{l}\text { Título do Projeto: Estudo antigênico e Genotípico do virus da raiva isolado de morcegos e carnivoros silvestres provenientes da região subtropical do } \\
\text { Brasil }\end{array}$} \\
\hline Nome da Instituição : REITORI & NIVERSIDADE DE SÃO PAULO & CNPJ: $63.025 .530 / 0001-04$ \\
\hline
\end{tabular}

Observações, ressalvas e condicionantes

As atividades de campo exercidas por pessoa natural ou juridica estrangeira, em todo o território nacional, que impliquem o deslocamento de recursos humanos e materiais, tendo por objeto coletar dados, materiais, espécimes biológicos e minerais, peças integrantes da cultura nativa e cultura popular, presente e passa da, obtidos por meio de recursos e técnicas que se destinem ao estudo, à difusão ou à pesquisa, estão sujeitas a autorização do Ministério de Ciência e Tecnologia. Esta autorização não exime o titular e a sua equipe da necessidade de obter as anuências previstas em outros instrumentos legais, bem como do consentimento \begin{tabular}{l} 
responsável pela área, pública ou privada, onde será realizada a atividade. \\
\hline Esta autorizaçăo não poderá ser utilizada para fins comerciais, industriais, esportivos ou para realizaçăo de atividades inerentes ao processo de licenciamento
\end{tabular} Esta autorização não poderá ser utilizada para fins comerciais, industriais, esportivos ou para realizaçáo de atividades inerentes ao processso de licención ambiental de empreendimentos. O material biológico coletado deverá ser utilizado para atividades cientificas ou didáticas no âmbito do ensino superior. A autorizçą̧áa para importação ou exportação de flora e fauna - CITES e não CITES). Em caso de material consignado, consulte www.ibama.gov.br/sisbio - menu

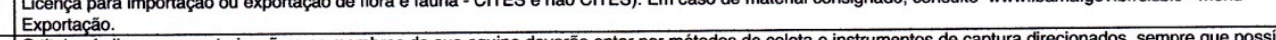
O titulaç de licença ou autorização e os membros da sua equipe deverão optar por métodos de clela e instrumentos de captura diracione não comprometa a viabiliti 5 ao grupo taxonômico de Este documento năo dispensa o cumprimento da legislaçăo que dispóe sobre acesso a componente do patrimônio genético existente no território nacional, na plataforma continental e na zona econômica exclusiva, ou ao conhecimento tradicional associado ao patrimônio genético, para fins de pesquisa científica,

bioprospecçăo e desenvolvimento tecnológico.

Em caso de pesquisa em Unidade de Conservaçăo Federal, o pesquisador titular deverá contactar a administração dessa unidade a fim de CONFIRMAR AS DATAS

das expediçōes, as condiç̋es para realizaçăo das coletas e de uso da infra-estrutura da unidade. 8 espécies ameaçadas de extinção, sobreexplotadas ou ameaçadas de sobreexplotação

Equipe

Equipe
\begin{tabular}{|l|l|l|l|l|l|}
\hline \multicolumn{1}{|c|}{ Nome } & \multicolumn{1}{|c|}{ Funçáo } & CPF & Doc. Identidade & Nacionalidade \\
\hline 1 & LUIZ FRANCISCO SANFILIPPO & AUXILIAR TECNICO & $126.632 .888-29$ & 17031631 SSP-SP & Brasileira \\
\hline 2 & Angelica Cristine de Almeida Campos & bióloga & $950.875 .086-34$ & Mg8138032 SSP-MG & Brasileira \\
\hline 3 & Danielle Bastos Araujo & Veterinária & $294.853 .608-19$ & $28237491-7$ SSP-SP & Brasileira \\
\hline
\end{tabular}

Locais onde as atividades de campo serão executadas

\begin{tabular}{|l|l|l|l|l|}
\hline$\#$ & Município & UF & Descricão do local & Tipo \\
\hline 1 & BERTIOGA & SP & Fazenda AcaraA & \\
\hline
\end{tabular}

Atividades X Táxons
\begin{tabular}{|l|l|l|}
\hline$\#$ & \multicolumn{1}{|c|}{ Atividade } & \multicolumn{1}{c|}{ Táxons } \\
\hline 1 & Captura de animais silvestres in situ & $\begin{array}{l}\text { Cerdocyon thous, Carollia perspicillata, Nasua nasua, Molossus molossus, Artibeus lituratus, } \\
\text { Herpailurus yaguarondi, Stumira lilium, Artibeus jamaicensis, Eira barbara, Didelphis aurita, } \\
\text { Desmodus rotundus, Platyrninus lineatus }\end{array}$ \\
\hline 2 & Coleta/transporte de amostras biológicas in situ & $\begin{array}{l}\text { Herpailurus yaguarondi, Cerdocyon thous, Desmodus rotundus, Carollia perspicillata, Nasua } \\
\text { nasua, Molossus molossus, Artibeus lituratus, Platyrnhinus lineatus, Sturnira lilium, Artibeus } \\
\text { jamaicensis, Eira barbara, Didelphis aurita }\end{array}$ \\
\hline 3 & Coleta/transporte de espécimes da fauna silvestre in situ & Desmodus rotundus ("Otde: 20) \\
\hline
\end{tabular}

* Qtde. de indivíduos por espécie/localidade/unidade de conservaçāo, a serem coletados durante um ano.

Material e métodos

Este documento (Autorização para atividades com finalidade cientifica) foi expedido com base na Instrução Normativa lbama $n^{\circ} 154 / 2007$. Através do código de autenticação abaixo, qualquer cidadão poderá verificar a autenticidade ou regularidade deste documento, por meio da página do Ibama/Sisbio na internet (www.ibama.gov.br/sisbio).

Código de autenticação: 63557632 
Ministério do Meio Ambiente - MMA

Instituto Brasileiro do Meio Ambiente e dos Recursos Naturais Renováveis - IBAMA

Instituto Chico Mendes de Conservação da Biodiversidade - ICMBio

Sistema de Autorização e Informação em Biodiversidade - SISBIO

Autorização para atividades com finalidade científica

\begin{tabular}{|l|c|c|}
\hline \multicolumn{1}{|c|}{ Número: 15486-2 } & Data da Emissão: 22/06/2009 13:26 & Data de Validade: 22/06/2010 \\
\hline
\end{tabular}
\begin{tabular}{|l|l|l|}
\hline Dados do titular & Nome: Silvana Regina Favoretto Lazarini & CPF: 045.706.968-64 \\
\hline $\begin{array}{l}\text { Rítulo do Projeto: Estudo antigênico e Genotípico do virus da raiva isolado de morcegos e carnivoros silvestres provenientes da região subtropical do } \\
\text { Brasil }\end{array}$ & CNPJ: 63.025.530/0001-04 \\
\hline Nome da Instituição : REITORIA DA UNIVERSIDADE DE SÃO PAULO &
\end{tabular}

\begin{tabular}{|l|l|l|}
\hline 1 & Amostras biológicas (Carnivoros) & Fragmento de tecido/órgăo, Sangue, Animal morto ou partes (carcaça)/osso/pele \\
\hline 2 & Amostras biológicas (Outros mamiferos) & Fragmento de tecido/orgāo, Animal morto ou partes (carcaça)/osso/pele, Sangue \\
\hline 3 & Método de captura/coleta (Carnivoros) & Armadiliha tipo gaiola com atracăo por iscas ("Box Trap//omahawk/Sherman") \\
\hline 4 & Método de captura/coleta (Outros mamiteros) & $\begin{array}{l}\text { Rede de neblina, Captura manual, Armadilha tipo gaiola com atraçăo por iscas ("Box } \\
\text { Trap/Tomahawk/Sherman") }\end{array}$ \\
\hline
\end{tabular}

Destino do material biológico coletado

\begin{tabular}{|l|l|l|}
\hline$\#$ & \multicolumn{1}{|c|}{ Nome local destino } & \multicolumn{1}{c|}{ Tipo Destino } \\
\hline 1 & REITORIA DA UNIVERSIDADE DE SAOO PAULO & coleçăo \\
\hline
\end{tabular}

Este documento (Autorização para atividades com finalidade científica) foi expedido com base na Instrução Normativa Ibama $n^{\circ} 154 / 2007$. Através do código de autenticação abaixo, qualquer cidadão poderá verificar a autenticidade ou regularidade deste documento, por meio da página do Ibama/Sisbio na internet (www.ibama.gov.br/sisbio).

Código de autenticação: 63557632 
Ministério do Meio Ambiente - MMA

Instituto Brasileiro do Meio Ambiente e dos Recursos Naturais Renováveis - IBAMA

Instituto Chico Mendes de Conservação da Biodiversidade - ICMBio

Sistema de Autorização e Informação em Biodiversidade - SISBIO

\section{Autorização para atividades com finalidade científica}

\begin{tabular}{|l|c|c|}
\hline \multicolumn{1}{|c|}{ Número: 15486-2 } & Data da Emissão: 22/06/2009 13:26 & Data de Validade: 22/06/2010 \\
\hline
\end{tabular}
\begin{tabular}{|l|l|l|}
\hline Rados do titular & Nome: Silvana Regina Favoretto Lazarini & CPF: 045.706.968-64 \\
\hline $\begin{array}{l}\text { Título do Projeto: Estudo antigênico e Genotipico do virus da raiva isolado de morcegos e carnivoros silvestres provenientes da região subtropical do } \\
\text { Brasil }\end{array}$ & CNPJ: 63.025.530/0001-04 \\
\hline
\end{tabular}

\section{Anexo para registrar Coletas Imprevistas de Material Biológico}

De acordo com a Instrução Normativa Ibama $n^{\circ} 154 / 2007$, a coleta imprevista de material biológico ou de substrato não contemplado na autorização ou na licença permanente deverá ser anotada na mesma, em campo específico, por ocasião da coleta, devendo esta coleta imprevista ser comunicada por meio do relatório de atividades. O transporte do material biológico ou do substrato deverá ser acompanhado da autorização ou da licença permanente com a devida anotação. O material biológico coletado de forma imprevista, deverá ser destinado à instituição científica e, depositado, preferencialmente, em coleção biológica científica registrada no Cadastro Nacional de Coleções Biológicas (CCBIO).

\begin{tabular}{|l|l|l|l|l|l|}
\hline Nivel & Táxon* & Qtde. & Amostra & Otde. & Data \\
\hline & & & & & \\
\hline & & & & & \\
\hline & & & & & \\
\hline & & & & & \\
\hline & & & & & \\
\hline & & & & & \\
\hline & & & & & \\
\hline & & & & & \\
\hline & & & & & \\
\hline
\end{tabular}

* Identificar o espécime no nivel taxonômico mais específico possivel.

Este documento (Autorização para atividades com finalidade científica) foi expedido com base na Instrução Normativa Ibama $n^{\circ} 154 / 2007$. Através do código de autenticação abaixo, qualquer cidadão poderá verificar a autenticidade ou regularidade deste documento, por meio da página do Ibama/Sisbio na internet (www.ibama.gov.br/sisbio)

Código de autenticação: 63557632 
ANEXO B
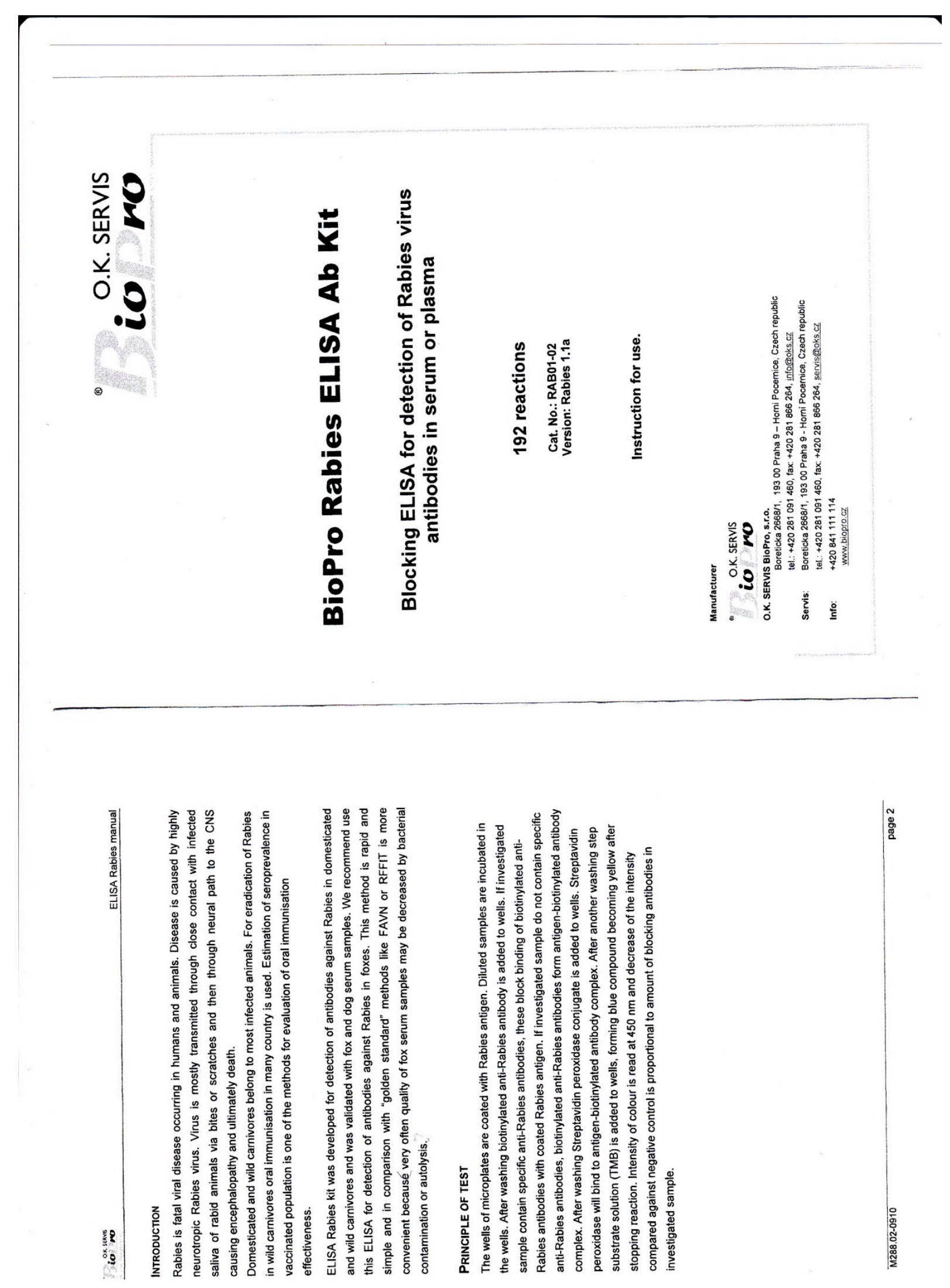